Running head: HUMAN HANDEDNESS: A META-ANALYSIS

\title{
Human handedness: A meta-analysis
}

\author{
Marietta Papadatou-Pastou ${ }^{1}$, Eleni Ntolka ${ }^{1}$, Judith Schmitz ${ }^{2}$, Maryanne Martin ${ }^{3}$, \\ Marcus R. Munafò ${ }^{4,5}$, Sebastian Ocklenburg ${ }^{6 *}$, Silvia Paracchini ${ }^{2 *}$ \\ ${ }^{1}$ School of Education, National and Kapodistrian University of Athens, Greece \\ ${ }^{2}$ School of Medicine, University of St Andrews, St. Andrews, UK \\ ${ }^{3}$ Department of Experimental Psychology, University of Oxford, UK \\ ${ }^{4} \mathrm{MRC}$ Integrative Epidemiology Unit at the University of Bristol, UK \\ ${ }^{5}$ School of Psychological Science, University of Bristol, UK \\ ${ }^{6}$ Biopsychology, Department of Psychology, Institute of Cognitive Neuroscience, \\ Ruhr University Bochum, Bochum, Germany
}

Address for correspondence: Dr. Marietta Papadatou-Pastou, School of Education, National and Kapodistrian University of Athens, 13A Navarinou Str., Athens 160 80, Greece.

Email: marietta.papadatou-pastou@seh.oxon.org, Tel: +30 2103641712

*Both authors contributed equally

(C) 2020, American Psychological Association. This paper is not the copy of record and may not exactly replicate the final, authoritative version of the article. Please do not copy or cite without authors' permission. The final article is available via its DOI: $10.1037 /$ bul0000229 


\begin{abstract}
Across time and place, right hand preference has been the norm, but what is the precise prevalence of left- and right-handedness? Frequency of left-handedness has shaped and underpinned different fields of research, from cognitive neuroscience to human evolution, but reliable distributional estimates are still lacking. While hundreds of empirical studies have assessed handedness, a large-scale, comprehensive review of the prevalence of handedness and the factors which moderate it, is currently missing. Here, we report five meta-analyses on hand preference for different manual tasks and show that left-handedness prevalence lies between $9.3 \%$ (using the most stringent criterion of left-handedness) to $18.1 \%$ (using the most lenient criterion of non-right-handedness), with the best overall estimate being $10.6 \%$ (10.4\% when excluding studies assessing elite athletes' handedness). Handedness variability depends on (a) study characteristics, namely year of publication and ways to measure and classify handedness, and (b) participant characteristics, namely sex and ancestry. Our analysis identifies the role of moderators which require taking into account in future studies on handedness and hemispheric asymmetries. We argue that the same evolutionary mechanisms should apply across geographical regions to maintain the roughly 1:10 ratio, while cultural factors, such as pressure against left-hand use, moderate the magnitude of the prevalence of left-handedness. Although handedness appears as a straightforward trait, there is no universal agreement on how to assess it. Therefore, we urge researchers to fully report study and participant characteristics as well as the detailed procedure by which handedness was assessed and make raw data publicly available.
\end{abstract}

Keywords: Handedness; Meta-Analysis; Laterality; Hand Preference; Cerebral Asymmetries 


\section{Public significance statements}

- To date, this meta-analysis is the largest reported study to estimate the prevalence of left hand preference for different manual tasks across geographical areas $(n=$ $2,396,170$ individuals). It shows that the best estimate for the prevalence of lefthandedness is $10.6 \%$. However, this value varies between $9.3 \%$ and $18.1 \%$, depending on how handedness is measured.

- The same evolutionary mechanisms should apply to participants of different geographical ancestries to maintain the roughly 1:10 ratio of left- versus right-handers found worldwide. The exact prevalence of left hand preference is moderated by cultural factors, primarily pressure to change writing hand, possibly due to direct instructions by parents and teachers and also through non-explicit model learning. More data is needed for individuals with less represented ancestries.

- When three handedness categories are given (left-handed, mixed-handed, righthanded), the best estimate for the prevalence of mixed-handedness is $9.33 \%$, a number almost as large as the prevalence of left-handedness. This highlights the importance of taking this group into account in future handedness studies.

- Hand preference measurement moderates the estimated prevalences of left- and righthandedness. We urge researchers to define universal criteria for measuring hand preference (short questionnaires, reporting both writing hand and Edinburgh Handedness Inventory [EHI] scores, and reporting at least two classifications, e.g. RL and R-M-L), as measurement imprecision and/or heterogeneity affects the estimated prevalence. Moreover, studies need to fully report study characteristics, such as instrument used to measure handedness (including questionnaire length and individual item content), response format, classification scheme, country in which the study took 
place, as well as population characteristics, such as sex, age, ancestry, educational and sporting level of the participants, ideally by uploading raw data in open-access repositories. Detailed reporting is essential to compare effectively different studies as well as to encourage good study design. 


\section{Human handedness: A meta-analysis}

Laterality is a general principle of functional organization in vertebrates (e.g., Bisazza, Rogers, \& Vallortigara, 1998; Güntürkün \& Ocklenburg, 2017; Ocklenburg, Isparta, Peterburs, \& Papadatou-Pastou, 2019; Rogers, 2008; Vallortigara \& Rogers, 2005). Homo sapiens have evolved laterality in a unique form within our primate lineage (Uomini \& Ruck, 2018). The population-level preferential use of the right hand has been the case at least since the days of Homo habilis, the precursor of modern Homo sapiens, two million years ago (Frayer et al., 2016; McManus, 2002). Recent estimations place the emergence of the righthand bias in the course of the last seven million years (Uomini \& Ruck, 2018).

Despite the fact that population-level right-hand preference is well established, the precise magnitude of the percentages of right- and left-handedness still remains to be elucidated. Handedness prevalence is indeed a point of dispute among different studies. Some of these differences might be explained by small sample sizes in individual studies, a problem that has been identified as one of the reasons for the current replication crisis in psychology. In addition to small sample sizes, inconsistent results are likely to be driven by publication bias, $p$-hacking, and heterogeneity in how handedness is measured. It has been suggested that one important methodological tool to avoid this problem and to identify true effects in psychological research are large-scale meta-analyses (Maxwell, Lau, \& Howard, 2015). A large-scale, comprehensive review of the prevalence of handedness and its moderators is currently lacking, despite the wealth of studies investigating handedness.

Solving the riddle of the prevalence of handedness is not an easy task, because of the large number of published studies on handedness. For example, entering the key word 'handedness' in PubMed in December 2019 resulted in 60,868 hits. A meta-analysis lends 
itself to producing an overview of all the primary studies using transparent methodology. By summarising a research domain in such a quantitative manner, meta-analyses protect against over-interpreting differences across studies, while allowing for even small studies to contribute to the results of the overall analysis, thereby providing a safety net against wasting data. Meta-analyses further allow for moderators to be identified and small study bias to be detected. Small study bias may be caused by publication bias (also termed ascertainment bias), but could also be caused by other factors such as systematic differences in study quality between small and large studies. Importantly, large-scale, highly-powered meta-analyses can help address the reproducibility issues that are at the forefront of scientific discussion within psychological research (e.g., Open Science Collaboration, 2015). Indeed, a number of publications have recently used meta-analysis to summarize the field of handedness (e.g., Ntolka \& Papadatou-Pastou, 2018; Markou, Ahtam, \& Papadatou-Pastou, 2017; see also Papadatou-Pastou, 2018).

Here we present five meta-analyses of studies that have measured hand preference to provide a reliable estimate of the prevalence of hand preference, disentangle the effects of the variables that are likely to moderate its magnitude, and to further estimate the possible presence of small study bias.

\section{Why handedness matters}

Understanding handedness and the prevalence of its different manifestations (i.e., left, non-right-, mixed-, and right-handedness, as well as ambidexterity) can be very informative in a range of research fields, such as neuroscience, genetics, psychiatry, cognitive psychology, psychoneuroendocrinology, as well as evolutionary biology. 
Handedness is a biological index -albeit indirect- of cerebral language lateralization. Knecht et al. (2000) in their seminal paper showed, using functional transcranial Doppler ultrasonography in a sample of 326 healthy participants, that the prevalence of right hemisphere language dominance increases linearly with the degree of left-handedness. More recent evidence reveals that most of the association between dominant hemispheres for language and hand use can be explained by the fact that strongly atypical individuals in terms of hemispheric lateralization are left-handers, although left-handedness can also found in participants with typical and ambilateral dominance (Mazoyer et al., 2014). Somers, Aukes et al. (2015) further showed that degree of hand preference and degree of language lateralization fit a cubic regression model with stronger left-hand preference linked to a higher chance of atypical language lateralization.

Research on the genetics of handedness has recently made great strides forward. The heritability of handedness is estimated to be around 24\% (Medland et al., 2009; Somers, Ophoff et al., 2015). This is a relatively modest value suggesting that non-genetic factors may also contribute to handedness. Indeed, a recent analysis of the UK Biobank data showed a number of significant environmental influences on handedness, for example birth year, birthweight, being part of a multiple birth, and season of birth (de Kovel, Carrion-Castillo, \& Francks, 2019). However, it has to be pointed out that while significant, these factors only had minimal predictive value for individual hand preference. Moreover, random measurement error could explain some of the variance.

In general, both genetic and non-genetic factors are being proposed for the emergence of human handedness (e.g., Güntürkün \& Ocklenburg, 2017; Ocklenburg et al., 2017; Ratnu, Emami, \& Bredy, 2017; Schaafsma, Riedstra, Pfannkuche, Bouma, \& Groothuis, 2009; Schmitz, Kumsta, Moser, Güntürkün, \& Ocklenburg, 2018; Schmitz, Metz, Güntürkün, \& 
Ocklenburg, 2017; Sparrow et al., 2016). Individual factors are expected to contribute very small effects explaining why extremely large samples are required to identify genetic variants associated with handedness. McManus, Davison, and Armour (2013) estimated that at least 40 loci are involved in determining handedness, based on the ENGAGE meta-analysis of genome-wide association analysis (GWAS). More recently, GWAS in $\sim 400,000$ samples of the UK Biobank led to the identification of just a handful of significant associations (de Kovel \& Francks, 2019; Wiberg et al., 2019). Different classifications did not impact on the overall results [(i) left-handers $(n=38,332)$ versus right-handers $(n=356,567)$; (ii) non-right handers $(n=44,631)$ versus right-handers $(n=356,567)$; and (iii) left-handers $(n=38,332)$ versus non-left-handers $(n=362,866)]$. The most recent GWAS was conducted in an impressive sample of 1,534,836 right-handed, 194,198 (11.0\%) left-handed and 37,637 (2.1\%) ambidextrous individuals and identified 48 variants reaching statistical significance (Cuellar Partida et al., 2019, preprint). The associations identified in these studies are enriched for genes that play a role in cellular pathways involved in neurodevelopment, such as neurogenesis, axonogenesis and in microtubule organization. Similar pathways were also identified in a much smaller GWAS conducted for a relative hand skill measure (Brandler et al., 2013).

As it is the case for most genetic studies, sampling is biased towards an overrepresentation of samples with European ancestries. Genetic data from different populations might help to address the question of the effects of ethnicity in influencing lefthandedness prevalence. Answering this question will require setting very specific criteria for assessing and defining handedness. Beyond the specific marker-trait associations, all the GWAS studies reported so far show an overlap between the genetic variation contributing to handedness and pathways implicated in neurodevelopmental and psychiatric disorders, such 
as schizophrenia and dyslexia. It has been suggested that this overlap might be mediated by biological factors involved in setting up left/right brain asymmetries (Brandler \& Paracchini, 2014).

The links between handedness and psychiatric disorders have been investigated for decades well before these GWASs. A large body of literature has shown a higher prevalence of non-right-handedness in a number of psychiatric disorders, such as schizophrenia, as mentioned above (Deep-Soboslay et al., 2010; Dragovic \& Hammond, 2005; Hirnstein \& Hugdahl, 2014; Ravichandran, Shinn, Öngür, Perlis, \& Cohen, 2017; Sommer et al., 2001; Tsuang, Chen, Kuo, \& Hsiao, 2016), but also depression (Denny, 2009), bipolar disorder (Ravichandran et al., 2017; van Dyck, Pittman, \& Blumberg, 2012), anxiety (Lyle, Chapman, \& Hatton, 2013), neurotic disturbances (Milenković, Brkić, \& Belojević, 2013), autism (Markou, Ahtam, \& Papadatou-Pastou, 2017), alcoholism (Domellöf, Rönnqvist, Titran, Esseily, \& Fagard, 2009), drug addiction (Preti et al., 2012), deafness (Papadatou-Pastou \& Sáfár, 2016), intellectual disability (Papadatou-Pastou \& Tomprou, 2015), and developmental disorders (Asenova, 2018). Therefore, having a robust estimate of the baseline of lefthandedness could be also informative for this line of clinical handedness research.

Understanding handedness will also contribute to our understanding of human evolution. For example, it has been claimed that 'right-handedness, along with the capacity to make and use tools, to use language, and to show functional and anatomical cerebral specialisation, are characteristics specific to humans, and that they are intimately tied together in the divergent evolution of man from the apes' (McManus, 2019). Importantly, left-handers represent a substantial percentage of the human population (Willems, Van der Haegen, Fisher, \& Francks, 2014). Therefore, when designing research studies, care should be taken so that left-handers are included in representative numbers. For example, evidence 
exists, albeit conflicting, that there are differences in the levels of testosterone between rightand left-handers (Moffat \& Hampson, 1996; Papadatou-Pastou, Martin, \& Mohr, 2017), and sample selection could be one of the factors resulting in these conflicting findings. Thus, if we are going to understand normal, but also pathological, functioning in terms of behaviour, brain functioning, endocrinology, and genetics it is important to account for the variation within handedness (Willems, Van der Haegen, Fisher, \& Francks, 2014).

\section{Factors that potentially moderate handedness prevalence}

Suggesting a genetic basis for handedness does not eliminate possible geneenvironment interactions. Indeed, a number of environmental factors have been proposed and are likely to be moderating the reported prevalence of handedness both within and between populations. The most obvious example is cultural pressures, such as forcing left-handers to use their right hand for everyday activities like eating in some countries (e.g., De Agostini, Khamis, Ahui, \& Dellatolas, 1997; Shimizu \& Endo, 1983; Fagard \& Dahmen, 2004) and most typically writing (e.g., Dellatolas et al., 1988; Vuoksimaa, Koskenvuo, Rose, \& Kaprio, 2009; Siebner et al., 2002). Other environmental factors include nutrition; for instance, a large-scale review and meta-analysis showed that breastfeeding before the age of nine months is associated with a decreased prevalence of non-right-handedness (Hujoel, 2018). There is also evidence that handedness may be influenced by season of birth (see Jones \& Martin, 2008; Martin \& Jones, 1999), with the proportion of births of left-handed people being higher within the spring and ensuing months (March-July in the northern hemisphere, September-January in the southern hemisphere) than within the other months.

Other factors that have been proposed to moderate the prevalences of left- and righthandedness can be largely grouped into (a) population characteristics and (b) study 
characteristics. Ancestry is one of the most studied population characteristics, with the prevalence of left-handedness found to be lower in Asia than in North America and Europe (Porac, Rees, \& Buller, 1990). This is most likely to be due to differential cultural pressures against left-hand use, considering that only $3.5 \%$ and $0.7 \%$ of schoolchildren living in China (Teng \& Lee, 1976) and Taiwan (Hung, Tu, Chen, \& Chen, 1985) respectively were found to be left-handed, but $6.5 \%$ of schoolchildren of Asian descent living in the United States at around the same time were found to use their left hand for writing (Hardyck, Goldman, \& Petrinovich, 1975). Indeed, a low prevalence of left-handedness has been repeatedly found in societies with high levels of conformity (Brain, 1977; Jung \& Jung, 2009; Komai \& Fukuoka, 1934; Kushner, 2013; Lien, Chen, Hsiao, \& Tsuang, 2015; Shimizu \& Endo, 1983; Suar, Mandal, Misra, \& Suman, 2013; Tsuang et al., 2016; Xu \& Zheng, 2015; Zverev, 2006). For example, Lien et al. (2015) measured handedness in a sample of 640 college students in Taiwan and their 1,328 first-degree relatives and only $2.89 \%$ of these participants reported to write with their left hand. Jung and Jung's study (2009) detected only 141 left-handers (5.8\%) among 2,437 randomly selected Koreans. In Suar's et al. (2013) study, only 3.98\% in a total of 3,698 participants in Kharagpur, India, wrote with their left hand. Zverev (2006) recorded self-reported hand preference in a sample of 440 participants (141 pupils, 68 teachers, 231 guardians) derived from a secondary school in Malawi, Central Africa, and only $4.3 \%$ and $4.7 \%$ of the sample self-reported to be left-handed or mixed-handed, respectively. Family data show that the effect of cultural pressure on handedness can be differentiated from genetic effects (McManus, 2009).

Age has also been suggested to moderate the prevalence of handedness, with evidence of a decrease in left-handedness with increasing age in cross-sectional studies (e.g., de Kovel et al., 2019; Jung \& Jung, 2009; Milenković et al., 2013; Preti et al., 2011). For example, 
Lee-Feldstein and Harburg (1982) have found that the proportion of left-handers is nearly twice as high for people under 40 years of age than for people that are over the age of 40 ( $14.8 \%$ vs. $8.4 \%$ for men and $13.4 \%$ vs. $7 \%$ for women). Kalisch, Wilimzig, Kleibel, Tegenthoff, and Dinse (2006) investigated hand motor performance in 20 to 90 year-old participants and found that the clear right-hand advantage seen in younger participants changed to a more balanced performance in older cohorts. Yet, older participants still selfidentified as right-handers. These effects, however, do not indicate that handedness changes when people grow older. Rather this seems to be a generational effect, for example changes in social norms towards left-handedness over the decades affect the prevalence of lefthandedness (Dellatolas et al., 1991, Hugdahl, Satz, Mitrushina, \& Miller, 1993).

A higher percentage of left-handers has been found among the high achievers in sporting populations (Grouios, Tsorbatzoudis, Alexandris, \& Brakoulis, 2000; Holtzen, 2000; Loffing, 2017; Loffing \& Hagemann, 2012; Raymond, Pontier, Dufour, \& Moller, 1996). According to Casey (1996) such advantages are neuroanatomically-based and facilitate lefthanded people in performing certain neurocognitive tasks, such as visuospatial and whole body tasks. The left hand and right hemisphere respond faster than the right hand and left hemisphere, thus it may be the case that the left hand is preferred in some sports, even by people otherwise right-handed (Carson, Chua, Elliott, \& Goodman, 1990). Wood and Aggleton (1989) support the hypothesis that any excess of left-handers in certain sports is simply due to the nature of the game. Left-handers merely have a tactical advantage, as they have more practice against right-handed opponents than right-handers have against lefthanders. More recently, Loffing (2017) suggested that the left-handers' advantage is linked to the underlying time pressure of some interactive sports, such as table tennis and cricket. 
Other population characteristics linked to handedness are homosexuality (Blanchard \& Lippa, 2007; Lalumiere, Blanchard, \& Zucker, 2000; Xu \& Zheng, 2017; Yule, Brotto, \& Gorzalka, 2014), being a twin (Medland et al. 2009; Sicotte, Woods, \& Mazziotta, 1999; Suzuki \& Ando, 2014; Vuoksimaa et al., 2009, but see Zheng et al., 2019, preprint), being a triplet (Heikkilä et al., 2018) as well as education (Elneel, Carter, Tang, \& Cuschieri, 2008; Faurie et al., 2008; Noroozian, Lofti, Gassemzadeh, Emami, \& Mehrabi, 2002; Gupta, Sanyal, \& Babbar, 2008; Kuderer \& Kirchengast, 2016; Lyle et al., 2013).

The key study characteristic influencing handedness is assessment, shown to contribute to frequency variation by introducing measurement artefacts (see Bishop, 1990). Assessment methods mainly include hand preference inventories and proficiency measures, assessing hand preference for everyday activities and relative hand skill respectively. Hand preference measures are the most widely used instruments, both in experimental and clinical settings, as they are easier and more convenient to use than relative hand skill measures (Borod, Herbert, \& Koff, 1984). But even amongst the different hand preference inventories one can find differences in patterns of distributions of the prevalence of right- and lefthandedness (Holder, 1992). Provins, Milner and Kerr (1982), for example, have reported collecting different percentages for different inventories resulting in even reclassifying some left-handers as clear right-handers. Self-classification consists of merely asking participants 'Are you right- or left-handed' (Faurie et al., 2008). However, using a sample balanced for handedness and sex, Papadatou-Pastou, Martin, and Munafò (2013) found that selfclassification matched writing hand in every case, while that the mismatch between selfclassification and hand preference inventories was $0.4 \%$ for right-handers, but $13.5 \%$ for lefthanders. 
The apparent prevalence of handedness may also vary by virtue of questionnaire length (Holder, 1992; Peters, 1992). This can vary from the use of a single item such as writing hand (e.g., Silva \& Satz, 1979) to the utilization of 75 items (e.g., Provins, Milner, \& Kerr, 1982). Still, when the number of items is kept constant, then the content of the questionnaire, that is the nature of the items used, could affect the distribution of the results (Bryden, 1977; Gureje, 1988). Further, the type of response allowed is important. PapadatouPastou et al. (2013) found that an 'either hand' response in a 5-point scale is more likely to be translated into a 'right hand' response when the same item is presented with a forced choice ('right' vs.' left') response option, especially for right-handers. Furthermore, left-handers give more extreme non-dominant hand responses that right-handers in 5-point scales and righthanders choose fewer 'either' responses.

The handedness classification scheme used by each researcher also has a substantial impact on the number of individuals allocated to each group. Handedness may be classified into either discrete categories (e.g., Chisnall, 2010; Dinsdale, Reddon, \& Hurd, 2011; Hannula, Bloigu, Majamaa, Sorri, \& Mäki-Torkko, 2012) or by considering handedness a continuous variable (e.g., Dane et al., 2009). In the first case, the categories are usually 'right' and 'left', with writing hand being the most common criterion for group assignment. One important factor to consider is whether there is a 'middle category' between left- and righthandedness and how it is defined. Ambidexterity and mixed-handedness are the most commonly used terms for this 'middle' category, although ambidexterity (being equally skilled with both hands for fine motor tasks) can be differentiated from mixed-handedness (preferentially using different hands for different tasks). However, the terms are often used interchangeably creating confusion. The allocation of individuals into different handedness categories depends on classification schemes with varying cut-offs. For example, in the 
Edinburgh Handedness Inventory (EHI) (Oldfield, 1971), the most commonly used handedness questionnaire, participants answer ten items about their preferred hand for everyday activities. Based on the number of left- and right-sided preferences as well as no preference for either hand, a so-called LQ (laterality quotient) is calculated. The LQ has a value between -100 (consistent left-handedness) and +100 (consistent right-handedness) and, based on their scores, individuals are categorized as having a specific hand preference. Unfortunately, these cut-off schemes often vary widely between different studies. For example, Fagard, Chapelain, and Bonnet (2015) categorized their participants into strong lefthanders (LQ between -100 and -90), mixed left-handers (LQ between -90 and -30 ), ambidexter (LQ between -30 and 30), mixed right-handers (LQ between 30 and 90) and strong right-handers (LQ between 90 and 100) based on their responses in a self-developed questionnaire. In contrast, Arning et al. (2015) grouped their participants into right-handers (LQ between 40 and 100), left-handers (LQ between -100 and -40) and mixed handers (LQ between -40 and 40 ). These are only two examples of the many different classification schemes used that highlight the importance to come to a general consensus on how to use these terms in order to ensure comparability between different studies.

\section{Scope of the present study}

Here we report five large-scale meta-analyses, which integrate research findings from the broad field of handedness, in order to produce a reliable estimate of the prevalence of handedness categories, namely left-, non-right-, and mixed-handedness versus righthandedness. We further investigate the effect of factors that have been suggested to moderate the prevalence of handedness. In particular, we examine (a) population characteristics, such as location of testing (as a proxy of the participants' ancestry), educational level, and 
belonging to a sporting elite and (b) study characteristics, such as the instrument used to measure handedness, the length of the questionnaire used, the response format, the year of the publication of the study, whether the measurement of handedness was the main purpose of the study, and whether handedness information was collected by self-report or not. Finally, the heterogeneity amongst the included studies and the presence of small study bias were assessed.

\section{Method}

\section{Study Selection}

The list of studies that were entered into the meta-analysis from October 2007 to June 2018 was compiled in five steps: (a) PubMed was searched using the search terms handedness AND (sex OR gender) NOT animal* NOT child* NOT adolescent* NOT infant* NOT imaging NOT functional NOT structural, (b) PsycINFO was searched using the terms handedness OR hand, (c) the cited literature of all articles that were eligible for inclusion was scanned, (d) the papers where the included studies were referenced were sought using the online database Google Search, and (e) an e-mail request (where e-mail addresses could be retrieved) was sent for missing or unpublished data to the authors of studies that were of our interest, in order to ensure that no pertinent study, published or unpublished, had been

overlooked. Our search strategy was based on the strategy followed by Papadatou-Pastou, Martin, Munafò, and Jones (2008). All their included studies were entered to represent the years 1927- (September) 2007, but was expanded to include steps $d$ and $e$ (described above). Data collection ended in June 2018 and 200 studies were included in the meta-analysis. Details about the method of literature search and data extraction between October 2007 and June 2018 are shown in Figure 1. Data extraction for the post October 2007 studies was 
performed by MPP and EN and disagreements were resolved by discussion. Intercoder agreement was 95\%. The PRISMA statement (Moher, Liberati, Tetzlaff, Altman, \& The PRISMA Group, 2009) on reporting items for systematic reviews and meta-analyses was followed.

Please insert Figure 1 about here.

\section{Inclusion and exclusion criteria}

The following criteria were set for inclusion of a dataset in the systematic review:

(a) Participants: Unless stated otherwise, we assumed that participants were healthy, heterosexual singletons. Data from participants acting as controls to twins or pathological populations were used (e.g., twin controls: Heikkilä et al. 2015; schizophrenia controls: Dane et al., 2009; Dragovic, Milenkovic, \& Hammond, 2008; Narret al., 2007; schizophrenia and bipolar disorder controls: Ravichandran et al., 2017; controls to homosexuals: Xu \& Zheng, 2017; Yule et al., 2014).

(b) Age: Participants were over the age of 16 years old. If aggregate data were presented across ages (e.g., '15-70’ yrs.; Ellis, Ellis, \& Marshall, 1988; ‘9-83'yrs.; Suar et al., 2013) where the majority of participants were over 16 yrs., these data were used (Dane \& Erzerumluogu, 2003, were the mean age was 15.81 was also included).

(c) Publication Language: Articles were written in English, as this is the language used by most scientific literature. An exception was made for the Azémar and Stein (1994) study, as the data were reported in Raymond et al. (1996). 
(d) Handedness assessment: Handedness was measured in terms of preference, not hand skill.

(e) No selection on the basis of handedness: Studies were excluded if participants were selected on the basis of their handedness, either to achieve exclusively righthanded samples or to increase the proportion of left-handed participants (e.g., Christman, Prichard, \& Corser, 2015; Lake \& Bryden, 1976; Liederman \& Healy, 1986; Tan, 1983).

Different studies classified their participants into different handedness groups. The most used classifications were Right-Mixed-Left (R-M-L), Right-Left (R-L), and RightnonRight (R-nonR). When more complex classifications were used (e.g., right-, right mixed-, left mixed-, and left-handed or seven-class classifications), they were converted to R-M-L when an odd number of classifications was used and R-L when an even number was used. Mixed-handedness included the middle handedness category, as defined and operationalized by the different studies included in the meta-analysis. For example, some studies named the middle category "mixed" (e.g., Hatta \& Kawakami, 2007), while others named the participants in the middle category "ambidextrous" (e.g., Chisnall, 2010; Holder, 1992; Jung \& Jung, 2009). When two or more samples from different geographical areas (e.g., de la Fuente, Casasanto, Román, \& Santiago, 2015) or from different age groups (Ocklenburg et al., 2016) were reported in the same article, they were treated as separate datasets. Nevertheless, if a sample was sub-divided into categories not meaningful for this systematic review, then all data were treated as a single dataset. For example, in the case of Lien et al. (2015) the handedness data from the parents and the siblings of college students were merged into a single dataset and in the case of Marmolejo-Ramos et al. (2017) three different college student samples were merged into one dataset. In the case of datasets that were published 
more than once (e.g., Annett, 1999; Narr et al., 2007; Tsuang et al., 2016) these were included only once. Because a robust sex difference has been shown in a large meta-analysis from our group (Papadatou-Pastou et al., 2008), studies in which information about the gender of each handedness group was not provided were not included (e.g., Corballis, Hattie, \& Fletcher, 2008). Data needed to be broken down by handedness groups and sex in a format that provided arithmetic data that could be used in the present analysis (i.e., not reporting only laterality quotients or $p$-values or providing only graphical representations of data).

\section{Moderator variables}

The variables that were extracted to test for possible moderating effects on the prevalence of handedness were the following (for a more detailed description see PapadatouPastou et al., 2008):

Instrument. The studies were coded for instrument using six different groupings, representing the most popular instruments used to measure handedness in the present dataset. These were: (a) Annett's Hand Preference Questionnaire (8-item, 10-item, 12-item, and 23item versions), (b) the Edinburgh Handedness Inventory (EHI; 10-item version), (c) writing hand, (d) self-classification, (e) the Briggs and Nebes modification of Annett's Hand Preference Questionnaire, (f) the four items on handedness from Coren and Porac's Laterality Inventory, and (g) observation or information from official records.

Classification scheme. The following schemes were used: Right-Mixed-Left (R-M-L), Right-Left (R-L), and Right-nonRight (R-nonR).

Response format. The response formats of the different instruments were grouped as follows: (a) binary forced choice format: this group includes the cases where participants had to make a forced choice (right or left) as well as the cases where participants had to tick a box 
next to a picture showing their hand posture, (b) 3-point graded response format: this group includes the cases where the response format was worded as follows: 'right, both, or left', 'right, either, or left', 'right, equally, or left', 'right, ambidextrous, or left', 'always right, either right or left, or always left', (c) 5-point graded response format, such as Likert scales ranging from 'always use the left hand' to 'always use the right hand', and (d) the graphic graded response format, that is the response format allowed in the original version of the EHI. The response format features two columns labelled 'right' and 'left' and participants are asked to indicate their preferences in the use of hands for the activities listed in the questionnaire by putting + in the appropriate column. For the items for which their preference is so strong that they would never try to use the other hand unless absolutely forced to, they are asked to put ++ If it is the case that participants are really indifferent they are asked to put + in both columns.

Ancestry. Rarely was information about ancestry reported, but it was rather inferred from the location in which the testing took place, resulting in three groupings: sub-Saharan African, European, and East Asian.

Education. Education was considered to be higher in individuals who had entered college (college students, faculty, and professionals) than all the other populations, corresponding to two groupings of educational status.

Additionally, information on whether the measurement of handedness was the main purpose of the study, whether participants belonged to a sporting elite (e.g., Loffing, 2017), and whether the data were collected by self-report were also extracted from the studies, using a 'yes/no' coding. In order to test for the possible moderating effects of the year of publication of the studies, mean age of participants, and the length of the questionnaire (i.e., number of questionnaire items used) numerical values were used. Year of publication was 
also used as a categorical variable with the groupings (a) < 1976, (b) 1976-1985, (c) 19861995, (d) 1996-2007, and (e) 2008-2019. Not all studies reported information for each of the above moderator variables.

\section{Statistical analysis}

Meta-analysis was carried out in R using the robumeta package (Fisher \& Tipton, 2015). The variation in the classification schemes used in the original studies did not allow for a single, overall analysis to take place without losing important information. Therefore, studies were assigned to at least one of five groups, according to the classification schemes they employed. The groups, which were analyzed in separate meta-analyses, were as follows:

1. Left-handedness (total): This comparison represents the overall presence of lefthandedness (in the case of R-L and R-M-L classifications) or non-right-handedness (in the case of R-nonR classifications). Therefore, information was included from all the datasets, regardless of the classification scheme employed. ${ }^{1}$

2. Non-right-handedness: Non-right-handers correspond to participants who were classified as non-right-handers in datasets where an R-nonR classification was employed.

3. Left-handedness (forced choice): Left-handers by forced choice correspond to participants who were classified as left-handers in datasets where an R-L classification was employed.

4. Left-handedness (stringent): Stringent left-handers correspond to participants who were classified as left-handers in datasets where an R-M-L classification was employed.

\footnotetext{
${ }^{1}$ Following Papadatou-Pastou et al. (2008), in the case of three studies where both the R-L and the R$\mathrm{M}-\mathrm{L}$ classifications were available for the same measures, information from the latter classification was used (Arning et al., 2015; Brito, Brito, Paumgartten, \& Lins, 1989; Saunders \& Campbell, 1985).
} 
5. Mixed-handedness: Mixed-handers correspond to participants who were classified as mixed-handers in datasets where an R-M-L classification was employed.

The following steps were followed:

Step 1: Handedness prevalence calculation: The atypical handedness rate (the number of left-, mixed- or non-right-handers in each dataset divided by the total number of participants) was calculated for each dataset independently (with corresponding 95\% confidence intervals $[\mathrm{CI}]$ ). A value of zero represents the absence of atypical-handers or a prevalence of $0 \%$.

Step 2: Meta-analysis was carried out in $\mathrm{R}$ using the robumeta package (Fisher \& Tipton, 2015) to perform meta-regression using correlated robust variance estimation (RVE) models.

Step 3: The homogeneity assumption within each grouping was tested using the $I^{2}$ index indicating the variance explained by study heterogeneity, and the $\mathrm{Tau}^{2}$ index specifying variance between studies statistics. According to Higgins, Thompson, Deeks, and Altman (2003), the $I^{2}$ index levels can be described as low, moderate, and high, when they fall close to $25 \%, 50 \%$, and $75 \%$ respectively.

Step 4: The Papadatou-Pastou et al. (2008) meta-analysis showed in a robust way that males are $23 \%$ more likely to be left-handed than females. Thus, sex was used as a moderator in each grouping and the handedness prevalence of males and females was compared using the $t$ statistic (and corresponding $p$-value).

Step 5: In order to investigate the presence of small study bias we used the funnel plot graphical test (funnel() function), Egger's regression test (regtest() function), and Duval and Tweedie's (2000) trim and fill method (trimfill() function) of the $\mathrm{R}$ metafor package (Viechtbauer, 2010). Small study bias may be caused by factors such as systematic 
differences between small and large studies or by publication bias which can exist when studies that do not produce the expected outcome remain disproportionately unpublished. Therefore the published datasets present a non-random sampling of the datasets that have investigated a given research question.

Step 6: Heterogeneity in a dataset may be caused by the presence of moderator variables. Although all groupings were found to be heterogeneous, a moderator variables analysis was conducted only for the left-handedness (total) grouping, as this was the most inclusive one.

\section{Data availability}

All datasets and code used for this analysis have been uploaded to the Open Science Framework repository (https://osf.io/wqf7j/) and as supplementary material in this submission.

\section{Results}

A total of $k_{t}=200$ studies were included in the different analyses, comprising $k_{d}=$ 262 separate datasets and totaling $n_{t}=2,396,170$ individuals $\left(n_{m}=1,112,365\right.$ male, $n_{f}=$ 1,283,805 female). Details of individual studies are shown in Table 1 and details of moderator variables in Table 2. The prevalence rates found for each grouping below are shown in Table 3 and the prevalence rates for each level of the moderator variables in Table 4.

Please insert Tables 1-4 about here. 
Overall effect estimates

Meta-analysis 1: Left-handedness (total): A total of $k=262$ datasets (from 200 studies) were included in the analysis, totalling $n=2,396,170$ individuals. Simple metaanalysis using robumeta gave an estimate of the left-handedness (total) prevalence of $10.60 \%$, with a $95 \%$ CI between $9.71 \%$ and $11.50 \%$ (see supplementary material Figure 1 ). Heterogeneity among the datasets was found to be high $\left(I^{2}=97.42 \%\right.$, $\left.\operatorname{Tau}^{2}=5.31\right)$. For females, the point estimate was $9.53 \%, 95 \% \mathrm{CI}=8.75 \%, 10.30 \%$. For males, the point estimate was $11.62 \%, 95 \% \mathrm{CI}=10.66 \%, 12.60 \%$. There was clear evidence that lefthandedness (total) prevalence was higher in males than in females $(+2.09 \%$, SE $=0.24 \%$, $95 \% \mathrm{CI}=1.61 \%, 2.57 \%, t(198)=8.59, p<.001)($ see Figure $2[\mathrm{~A}])$.

Please insert Figure 2 about here.

Egger's regression test for funnel plot asymmetry revealed clear evidence for small study bias $(z=-4.24, p<.001)$, as did the visual inspection of the funnel plot (see Figure 2 [B]). According to the trim and fill test, 53 studies $(\mathrm{SE}=10.60)$ will need to be imputed to the right of the mean, corresponding to higher left-handedness (total) rates in order for the funnel plot to be symmetrical (the two unpublished datasets by Dane were not included in this analysis).

Meta-analysis 2: Non-right-handedness: A total of $k=26$ datasets (from 24 studies) were included in the analysis, totaling $n=1,203,403$ individuals. Simple meta-analysis using robumeta gave an estimate of the non-right-handedness prevalence of $18.10 \%$ with a $95 \% \mathrm{CI}$ $=13.90 \%, 22.30 \%$. Heterogeneity among the datasets was found to be high $\left(I^{2}=99.56 \%\right.$, $\left.\mathrm{Tau}^{2}=83.29\right)$. For females, the point estimate was $16.20 \%, 95 \% \mathrm{CI}=12.00 \%, 20.30 \%$. For 
males, the point estimate was $19.80 \%, 95 \% \mathrm{CI}=15.10 \%, 24.60 \%$. There was evidence that non-right-handedness prevalence was higher in males than in females $(+3.66 \%$, SE $=1.46 \%$, $95 \% \mathrm{CI}=0.63 \%, 6.69 \%, t(22)=2.50, p<.05)($ see Figure $2[\mathrm{C}])$.

Egger's regression test for funnel plot asymmetry revealed no evidence for small study bias $(z=-1.15, p=.252)$, although visual inspection of the funnel plot indicated asymmetry (see Figure $2[\mathrm{D}])$. According to the trim and fill test, seven studies (SE $=3.37$ ) will need to be imputed to the left of the mean, corresponding to lower non-right-handedness rates, in order for the funnel plot to be symmetrical.

Meta-analysis 3: Left-handedness (forced choice): A total of $k=173$ datasets (from 123 studies) were included in the analysis, totaling $n=413,560$ individuals. Simple metaanalysis using robumeta gave an estimate of the left-handedness (forced choice) prevalence of $10.20 \%$ with a $95 \% \mathrm{CI}=9.14 \%, 11.20 \%$. Heterogeneity among the datasets was found to be high $\left(I^{2}=96.52 \%\right.$, Tau $\left.{ }^{2}=16.28\right)$. For females, the point estimate was $9.15 \%, 95 \% \mathrm{CI}=$ $8.16 \%, 10.10 \%$. For males, the point estimate was $11.50 \%, 95 \% \mathrm{CI}=10.24 \%, 12.80 \%$. There was clear evidence that left-handedness (forced choice) prevalence differed between males and females $(+2.35 \%, \mathrm{SE}=0.37 \%, 95 \% \mathrm{CI}=1.61 \%, 3.09 \%, t(121)=6.30, p<.001)(\mathrm{see}$ Figure $2[\mathrm{E}])$.

Egger's regression test for funnel plot asymmetry revealed clear evidence for small study bias $(z=-2.96, p<.01)$, as did the visual inspection of the funnel plot (see Figure 2, $[\mathrm{F}])$. According to the trim and fill test, 27 studies $(\mathrm{SE}=8.59)$ will need to be imputed to the right of the mean, corresponding to higher left-handedness (forced choice) rates in order for the funnel plot to be symmetrical. (The two unpublished datasets by Dane were not included in this analysis.) 
Meta-analysis 4: Left-handedness (stringent): A total of $k=72$ datasets (from 63 studies) were included in the analysis, totaling $n=789,090$ individuals. Simple meta-analysis using robumeta gave an estimate of the left-handedness (stringent) prevalence of $9.34 \%$ with a $95 \% \mathrm{CI}=7.92 \%, 10.80 \%$. Heterogeneity among the datasets was found to be high $\left(I^{2}=\right.$ $\left.97.07 \%, \mathrm{Tau}^{2}=5.57\right)$. For females, the point estimate was $8.88 \%, 95 \% \mathrm{CI}=7.43 \%, 10.30 \%$. For males, the point estimate was $9.74 \%, 95 \% \mathrm{CI}=8.45 \%, 11.00 \%$. There was evidence that left-handedness (stringent) prevalence differed between males and females $(+0.86 \%$, SE $=$ $0.30 \%, 95 \% \mathrm{CI}=0.27 \%, 1.45 \%, t(61)=2.90, p<.01)($ see Figure $2[\mathrm{G}])$.

Egger's regression test for funnel plot asymmetry revealed evidence for small study bias $(z=-2.48, p<.05)$, as did visual inspection of the funnel plot (see Figure 2, $[\mathrm{H}]$ ). According to the trim and fill test, 18 studies $(\mathrm{SE}=5.56)$ will need to be imputed to the right of the mean, corresponding to higher left-handedness (stringent) rates in order for the funnel plot to be symmetrical.

Meta-analysis 5: Mixed-handedness: A total of $k=72$ datasets (from 63 studies) were included in the analysis, totaling $n=789,090$ individuals. Simple meta-analysis using robumeta gave an estimate of the mixed-handedness prevalence of $9.33 \%$ with a $95 \% \mathrm{CI}=$ $6.67 \%, 12.00 \%$. Heterogeneity among the datasets was found to be high $\left(I^{2}=99.32 \%\right.$, Tau ${ }^{2}=$ 95.45). For females, the point estimate was $8.53 \%, 95 \% \mathrm{CI}=6.01 \%, 11.00 \%$. For males, the point estimate was $10.84 \%, 95 \% \mathrm{CI}=7.78 \%, 13.90 \%$. There was clear evidence that mixedhandedness prevalence differed between males and females $(+2.31 \%, \mathrm{SE}=0.45 \%, 95 \% \mathrm{CI}=$ $1.42 \%, 3.20 \%, t(61)=5.18, p<.001)($ see Figure $2[I])$.

Egger's regression test for funnel plot asymmetry revealed clear evidence for small study bias $(z=-3.56, p<.001)$, as did visual inspection of the funnel plot (see Figure $2[\mathrm{~J}]$ ). However, according to the trim and fill test, no studies needed to be 'trimmed' or 'filled'. 


\section{Moderating variables analysis}

Because of the heterogeneity detected among studies, the moderating effects of the previously described variables were tested within the left-handedness (total) comparison, which was the most inclusive.

Publication year: Meta-regression of publication year as a continuous variable revealed no evidence of a moderating effect on the prevalence of left-handedness $(p=.111)$. There was also no indication of a sex by year of publication interaction $(p=.860)$. When year of publication was used as a categorical variable, the prevalence of left-handedness was found to be $7.19 \%$ (95\% CI 5.62\%, 8.76\%) when studies were published before 1976 (18 datasets), 10.73\% (95\% CI 8.81\%, 12.65\%) when studies were published between 1976 and 1985 (69 datasets), 10.64\% (95\% CI 8.90\%, 12.38\%) when studies were published between 1986 and 1995 (70 datasets), $11.70 \%$ (95\% CI 9.57\%, 13.82\%) when studies were published between 1996 and 2007 (46 datasets) and 10.77\% (95\% CI 8.62\%, 12.92\%) when studies were published between 2008 and 2019 (57 datasets) (see Figure 3). There was evidence that the prevalence of left-handedness (total) was higher in $1976-1985(+3.54 \%$, SE $=1.26 \%, 95 \% \mathrm{CI}$ $1.06 \%, 6.02 \%, t(194)=2.82, p<0.01), 1986-1995(+3.45 \%, \mathrm{SE}=1.19 \%, 95 \%$ CI $1.11 \%$, $5.80 \%, t(194)=2.90, p<0.01), 1996-2007(+4.51 \%, \mathrm{SE}=1.34 \%, 95 \%$ CI $1.87 \%, 7.15 \%$, $t(194)=3.37, p<0.001)$ and $2008-2019(+3.58 \%, \mathrm{SE}=1.35 \%, 95 \%$ CI $0.92 \%, 6.24 \%$, $t(194)=2.65, p<0.01)$ compared to the earliest studies published before 1976 . There was no indication of a sex by year of publication (categorical) interaction (all $p>.315$ ).

Please insert Figure 3 about here. 
Self-Reporting: The prevalence of left-handedness was found to be $10.50 \%$ (95\% CI 9.58\%, $11.40 \%$ ) when handedness was self-reported (232 datasets) and $11.90 \%$ (95\% CI $8.22 \%$, $15.60 \%)$ when it was not self-reported (28 datasets). However, there was no statistical evidence for a difference $(p=.458)$ dependent upon whether handedness was self-reported or not. There was also no indication of a sex by report interaction $(p=.752)$.

Classification: There was clear evidence for a moderating effect of classification. The prevalence of left-handedness was found to be $16.57 \%$ (95\% CI $12.85 \%, 20.30 \%)$ when using a nonR-R classification (22 datasets), 10.16\% (95\% CI 9.10\%, 11.20\%) when using a R-L classification (170 datasets) and 9.49\% (95\% CI 7.93\%, 11.00\%) when using a R-M-L classification (70 datasets) (see Figure 4). There was clear evidence that the estimated prevalence for the R-L classification $(-6.41 \%, \mathrm{SE}=1.97 \%, 95 \% \mathrm{CI}-10.30 \%,-2.53 \%, t(197)$ $=-3.26, p<.01)$ and the estimated prevalence for the R-M-L classification $(-7.09 \%, \mathrm{SE}=$ $2.05 \%, 95 \%$ CI $-11.10 \%,-3.05 \%, t(197)=-3.46, p<.001)$ were lower compared to the nonR-R classification. Moreover, there was evidence of a sex by classification interaction due to males showing more reduction of left-handedness prevalence than females when using a R-M-L classification $(-3.78 \%, \mathrm{SE}=1.30 \%, 95 \% \mathrm{CI}-6.35 \%,-1.21 \%, t(194)=-2.90, p<$ $.01)$ as compared to a nonR-R classification. There was no sex by classification interaction for the R-L classification $(p=.084)$.

Please insert Figure 4 about here.

Instrument: The instrument used for handedness assessment was extracted from 144 studies (183 datasets). The prevalence of left-handedness was found to be $9.29 \%$ (95\% CI $8.45 \%$, 
$10.10 \%)$ when assessed as writing hand (71 datasets), $13.51 \%$ (95\% CI 10.29\%, 16.70\%) when assessed using the EHI (47 datasets), 12.63\% (95\% CI 4.29\%, 21.00\%) when assessed using Annett's Handedness Questionnaire (6 datasets), 9.24\% (95\% CI 8.07\%, 10.40\%) when assessed as self-classification, 9.73\% (95\% CI 8.23\%, 11.20\%) when assessed using Briggs and Nebes Questionnaire (6 datasets), 9.75\% (95\% CI 8.95\%, 10.50\%) using Porac and Coren's Questionnaire (9 datasets) and 15.11\% (95\% CI 9.15\%, 21.10\%) when handedness was observed (15 datasets) (see Figures $5 \& 6$ ). There was no evidence that prevalence estimates were different from writing hand assessment when handedness was assessed with Annett's Handedness Questionnaire, self-classification, Briggs and Nebes Questionnaire, Porac and Coren's Questionnaire or when handedness was observed (all $p>.057$ ). However, there was evidence that the prevalence of left-handedness was higher when assessed using the EHI as compared to writing hand assessment $(+4.22 \%, \mathrm{SE}=1.69 \%, 95 \% \mathrm{CI} 0.89 \%, 7.55 \%$, $t(137)=2.50, p<.05)$. When assessed using Annett's Hand Preference Questionnaire, the estimated prevalence of left-handedness was higher compared to writing hand only in males $(+3.11 \%, \mathrm{SE}=1.02 \%, 95 \%$ CI $1.10 \%, 5.13 \%, t(129)=3.05, p<.01)$. There was no evidence for an interaction of other instruments and sex (all $p>.158$ ).

Please insert Figures 5 and 6 about here.

Writing hand was the most common criterion used to measure handedness. Therefore, the prevalence of handedness when assessed using writing hand was compared to all other instruments. The prevalence of left-handedness was found to be $11.19 \%$ (95\% CI $9.97 \%$, $12.40 \%$ ) when assessed using any instrument other than writing hand (187 datasets) and $9.32 \%(95 \%$ CI $8.50 \%, 10.10 \%)$ when assessed as writing hand (71 datasets). There was 
evidence for lower prevalence of left-handedness when assessing handedness as writing hand $(-1.88 \%, \mathrm{SE}=0.74 \%, 95 \%$ CI $-3.34 \%,-0.41 \%, t(196)=-2.53, p<.05)$. There was no evidence for a sex by instrument category interaction $(p=.108)$.

Purpose of study: The prevalence of left-handedness was found to be $10.10 \%(95 \%$ CI $8.88 \%, 11.30 \%$ ) when the measurement of handedness was the main purpose of the study (161 datasets) and $11.40 \%$ (95\% CI 10.11\%, 12.70\%) when it was not (100 datasets). There was no evidence of a moderating effect of main purpose $(p=.147)$. There was also no indication of a sex by main purpose interaction $(p=.053)$.

Education: Level of education was extracted from 186 studies (243 datasets). The prevalence of left-handedness was found to be $11.40 \%$ (95\% CI 9.86\%, 12.90\%) when the study participants were college students, professionals, or university faculty (101 datasets) and $10.10 \%(95 \%$ CI $8.92 \%, 11.30 \%)$ in general population samples (142 datasets). There was no evidence of a difference in prevalence between samples $(p=.195)$, nor of an indication of a sex by education interaction $(p=.051)$.

Ancestry: Ancestry was extracted from 167 studies (216 datasets). There was clear evidence of a moderating effect of ancestry. The prevalence of left-handedness was found to be $11.12 \%(95 \%$ CI $10.09 \%, 12.15 \%)$ when the study participants were of European ancestry (184 datasets), $7.71 \%(95 \%$ CI $6.25 \%, 9.18 \%)$ when the study participants were of subSaharan African ancestry ( 9 datasets), and 5.69\% (95\% CI 3.49\%, 7.88\%) when study participants were of East Asian ancestry (23 datasets) (see Figure 7). There was clear evidence of a moderating effect of ancestry with lower estimated prevalence of left- 
handedness for sub-Saharan African and East Asian participants (sub-Saharan Africa: $3.40 \%, \mathrm{SE}=0.91 \%, 95 \% \mathrm{CI}-5.19 \%,-1.61 \%, t(164)=-3.76, p<.001$, East Asia: $-5.43 \%, \mathrm{SE}$ $=1.23 \%, 95 \% \mathrm{CI}-7.85 \%,-3.01 \%, t(164)=-4.43, p<.001)$ than for European participants. There was no evidence of a sex by geographical ancestry interaction (all $p>.594)$.

Please insert Figure 7 about here.

Questionnaire length: Meta-regression of questionnaire length revealed no evidence of a moderating effect on the prevalence of left-handedness $(p=.133)$. There was also no indication of a sex by questionnaire length interaction $(p=.153)$.

Response format: Response format was extracted from 133 studies (172 datasets). The prevalence of left-handedness was found to be $9.74 \%(95 \%$ CI $7.90 \%, 11.60 \%)$ when participants had to respond making a forced choice between 'right' and 'left' (43 datasets), $10.34 \%(95 \%$ CI $9.00,11.70 \%)$ when participants were given a three-way response format (79 datasets), $11.26 \%$ (95\% CI 8.07\%, 14.40\%) when participants could respond on a 5-point scale (40 datasets), and 10.50\% (95\% CI 5.98\%, 15.00\%) when the original response format of the EHI was given (10 datasets). Compared to a binary format, the prevalence estimate did not differ when participants were given a three-way response format, a 5-point scale or when the original response format of the EHI was given (all $p>.410$ ). There was no evidence of a sex by response format interaction (all $p>.299)$.

Sporting elite: Left-handedness was higher in the elite sport group $(14.70 \%, 95 \%$ CI $9.72 \%$, $19.80 \%)$ compared to the general population $(10.40 \%, 95 \%$ CI $9.52 \%, 11.30 \%)$. However, 
the former group was based on a much smaller sample (12 datasets) and presented higher variance probably due to a wide range of different sports. The comparison between general population and sporting elite samples thus failed to reach significance $(p=.095)$. There was also no indication of a sex by sport interaction $(p=.211)$.

Mean age: Mean age was extracted from 63 datasets (54 studies). Meta-regression of mean age revealed no evidence of a moderating effect of mean age on the prevalence of lefthandedness $(p=.102)$. There was also no indication of a sex by age interaction $(p=.124)$.

\section{Discussion}

The present set of five meta-analyses integrates data on $n_{t}=2,396,170$ individuals. Depending on the criterion for the classification of study participants, the prevalence of lefthandedness was in the range of $9.34 \%$ (using the most stringent criterion of left-handedness) to $18.10 \%$ (using the most lenient criterion of non-right handedness), with an overall estimate of $10.60 \%$ for left-handedness (total). The estimate dropped to $10.40 \%$ when excluding the studies that assessed the handedness of elite athletes, who can be argued to be under selection bias according to theories suggesting a left-handedness advantage in some sports (e.g., Loffing, 2017). A sex difference was detected regardless of how participants were grouped, in line with previous findings (Papadatou-Pastou et al., 2008; Martin, Papadatou-Pastou, Jones, \& Munafò, 2010).

The field of handedness is known for the notorious variations in the methodology that is used to actually measure handedness in different studies. This was reflected in the number of moderators that were found to effect the estimate of prevalence rates for left-handedness (total). The instrument used to measure handedness produced different prevalences with self- 
report of handedness resulting in the lowest prevalence of left-handedness (9.24\%), closely followed by writing hand $(9.29 \%)$, with studies using different questionnaires giving a prevalence of around 10\%-13\% and observation giving the highest prevalence $(15.11 \%)$. Indeed, we have previously shown in a sample of 200 participants balanced for handedness and sex that participants' responses match when asked to indicate their handedness as writing hand and when asked to self-report their handedness and that there is an average $6.9 \%$ mismatch between writing hand and hand preference questionnaires (Papadatou-Pastou et al., 2013). When handedness information was collected by self-report measures (e.g., questionnaires filled in by the participants), the prevalence was slightly lower $(10.50 \%)$ compared to when it was not (e.g., the prevalence when measured by filial report was $11.90 \%$ ), but there was no clear statistical evidence for this difference. There was also no clear statistical evidence for the moderating effect of the number of items used to assess handedness or similarly for the response type available to participants. Therefore, shorter questionnaires can be employed in place of longer and more time-consuming ones without affecting the findings.

Another aspect troubling handedness researchers is that different studies classify their participants using different groupings, all the way from two-way groupings (e.g., R-L or RnonR) to seven or more groupings. In order to account for this variance we performed different meta-analyses for the different groupings. We also investigated the possible moderating effect of classification within the left-handedness (total) grouping, which included all studies. We found that the prevalence of left-handedness drops as criteria become stricter. More specifically, the prevalence of left-handedness was $16.57 \%, 10.16 \%$, and 9.49\% when using a nonR-R, R-L, and R-M-L classification, respectively, with a clear moderating effect of classification $(p<.001)$. This finding highlights the importance of 
reaching a consensus amongst handedness researchers on what the optimal classification of handedness is. We suggest that researchers report at least two different classifications of handedness (R-L and R-M-L) and that they further make their raw data available in open access repositories, such as the Open Science Framework (osf.org).

The issue of handedness classification is particularly relevant to the middle category in handedness studies, usually referred to as ambidexterity or mixed-handedness. For example, large studies such as the GWAS by Cuellar Partida et al. (2019, preprint) used a classification of ambidexterity based on self-reported hand preference for writing. The ambidexterity category was available for the UK Biobank sample (1.6\%) and 23andMe (2.5\%). Other studies, however, used more inclusive criteria for the middle category, resulting in a higher percentage of individuals in this group. For example, our data show that LQ measures identify $9.33 \%$ mixed-handedness, which is a figure almost as high as lefthandedness. As the exact definition of the ambidextrous / mixed-handed classification might influence the outcome of studies, it is key to ensure that future studies capture this dimension beyond the binary left/right preference. The ability to systematically capture mixedhandedness in large studies might improve the power to address some of the questions around handedness research. For example, identifying the $\sim 9 \%$ of mixed-handed individuals in the UK Biobank might improve the resolution of genetic mapping.

Year of publication was also found to affect the prevalence of handedness, although only when measured as a categorical variable. Thus, in more recent publications, the reported prevalence of left-handedness was higher than in very early studies (published before 1976). This is consistent with the results of cross-sectional studies which typically report lower rates of left-handedness among older compared to younger generations (Lee-Feldstein \& Harburg, 1982) and new large-scale studies that show increased left-handedness among younger 
individuals (de Kovel et al., 2019). Fleminger, Dalton, and Standage (1977) have considered the age differences in handedness to be a natural tendency towards dextrality. Lalumiere, Blanchard, and Zucker (2000) argue that this trend reflects either cohort effects or biased mortality rates associated with handedness, a rather popular view (Coren, 1989; Coren \& Halpern, 1991). Porac and Coren's (1981) developmental hypothesis, on the other hand, postulates that this decrease in the prevalence of left-handedness reflects the pressure of living in a right-handed world. Another influential theory is that of the gradual easing of cultural pressures against sinistrality (Schachter, Ransil, \& Geschwind, 1987). However, increasing rates of left-handedness have been found to be coupled with increasing rates of left-arm waving, a behaviour not subject to social pressure, as studied in old films (McManus \& Hartigan, 2007). A variant of this theory is that because in the earlier years of the last century left-handedness represented a social stigma, individuals may have concealed their true handedness in questionnaire surveys (McManus, 1984). Gilbert and Wysocki (1992) report data from over 1,100,000 individuals and show that the prevalence of left-handedness was only $3 \%$ for those born in 1900 rising up to almost $12 \%$ for those born in 1945 onwards. The effect has also been attributed to the underreporting of left-handedness in parents by their offspring (Kang \& Harris, 1996). On the other hand, McManus, Moore, Freegard, and Rawles (2010) claim that left-handers are more likely to respond to surveys about handedness and that this response bias is growing. The age effect might also be an artefact due to the fact that re-learning is more likely for older people. The increase in the estimated left-handedness rate further indicates that active instructions are likely to be a non-genetic factor that influences handedness, as this increase in left-handedness over time is likely to be caused by a reduction of forcing left-handers to use the right hand for writing in schools (de Kovel et al., 2019; Klöppel, Mangin, Vongerichten, Frackowiak, \& Siebner, 2010). 
Participants' characteristics were also found to moderate the estimate of the prevalence of left-handedness. Ancestry group was found to moderate the estimates of the prevalence of handedness in different studies, supporting the idea that cultural effects affect handedness (Laland, Kumm, Van Horn, \& Feldman, 1995; Laland, 2008). Participants of European ancestry had a much higher prevalence of left-handedness $(11.12 \%)$ compared to participants of sub-Saharan African ancestry (7.71\%), or of East Asian ancestry (5.69\%). The moderating effects of ancestry could be either due to (a) genetics, (b) prenatal testosterone levels and its geographical variations (Raymond \& Pointier, 2004), or (c) cultural factors. We favour the last explanation, as studies have shown that participants coming from families with backgrounds with low percentages of left-handedness, but having been raised in the western world show similar prevalence of left-handedness as the population of the country they have been raised in (Laland et al., 1995). This might happen due to direct instructions by parents and teachers or also through non-explicit model learning.

The cultural hypothesis is also supported by a recent study showing that the rate of non-right-handedness in Hong Kong (about 8\%) is higher than in most previous studies in Asian populations (Zheng et al., 2019, preprint). This could be due to the greater Westernization in Hong Kong compared to many other Asian areas. Importantly, the prevalence of non-right-handedness increased up to $13 \%$ when it was assessed using the preferred hand for drawing, not writing. This suggests that cultural pressures might be specific for writing and do not affect other behaviors to the same extent.

Studies that included individuals with higher levels of education (e.g., college students, professionals, or university faculty) reported elevated levels of left-handedness prevalence $(11.40 \%)$ compared to studies that used general population samples $(10.10 \%)$, albeit there was no statistical evidence for this difference. Similarly, members of sporting 
elites were found to have a $14.70 \%$ prevalence of left-handedness as opposed to $10.40 \%$ for the general population. The trend towards higher left-handedness prevalence in sporting elites is possibly due to the nature of interactive sports giving left-handers an advantage as righthanders have less practice with left-handed opponents (Loffing, 2017; Loffing \& Hagemann, 2012, 2016; Wood \& Aggleton, 1989). Even though the present systematic review did not locate enough datasets to test this hypothesis, the two studies that did make this comparison showed that it is interactive sports that are associated with elevated levels of left-handedness (Grouios et al., 2000; Loffing, 2017). However, Loffing, Sölter, and Hagemann (2014) showed that left-preference for sport does not always translate into left-handedness for the everyday tasks typically assessed in laterality studies.

Findings also show an effect of sex, suggesting a lower prevalence of left-handedness (total) in females $(9.53 \%)$ than in males $(11.62 \%)$. This supports the hypothesis that sex hormones might be one of the non-genetic factors that influence the ontogenesis of handedness and hemispheric asymmetries in general (Hausmann, 2017; Geschwind \& Galaburda, 1987). Note that a similar sex effect (females $=8.6 \%$, males $=10.6 \%$ ) was also observed in a recent analysis of non-genetic influences on handedness in the UK Biobank Cohort (de Kovel et al., 2019). Such an independent replication of an effect in both a largescale individual study and a large-scale meta-analysis indicates that this effect is unlikely to be caused by spurious findings. The most obvious genetic effect on sex-bias would implicate the sex chromosomes. It has been argued that left-handedness could be associated recessively, and with low penetrance, with a genetic variation located on the $\mathrm{X}$ chromosome (Jones \& Martin, 2000; but also see McManus, 2010). Priddle and Crow (2013) have suggested that the $\mathrm{X}$ chromosome and specifically the protocadherin $11 \mathrm{X} / \mathrm{Y}(P C D H 11 X / Y)$ gene pair has a central role for handedness, but adequate empirical support has not yet been 
amassed. Moreover, Arning et al. (2015) reported a role for the androgen receptor CAGrepeat length, located on the $\mathrm{X}$ chromosome for handedness, which partly replicated the work of Medland et al. (2005). Of note, a model for the genetics of sex differences in handedness has been suggested by McManus and Bryden (1992), implying that an X-chromosomal modifier gene might be responsible for sex differences in handedness. However, the most recent GWAS did not detect any associations on the X chromosome (Cuellar Partida et al., 2019).

In the current study, only studies measuring hand preference and not hand skill were included. Preference and skill represent two rather distinct concepts which have been suggested to be independently lateralized (Triggs, Calvania, Levine, Heaton, \& Heilam, 2000), with preference being considered as primary (McManus, Murray, Doyle, \& BaronCohen, 1992). Nevertheless, preference is correlated with measures of relative hand skill with an estimated correlation of magnitude of +.62 to +.73 (Todor \& Doane, 1977) or more recent estimates of +.50 to +.57 (Triggs et al., 2000), while Corey, Hurley and Foundas (2001) found that in more than $90 \%$ of cases, preference-based groups corresponded to groups based on relative hand skill. A recent study also showed that the correlation between hand preference and relative hand skill highly depends on which test is used to assess relative hand skill (Buenaventura Castillo et al., 2019, preprint). The authors assessed the relationship of hand preference with measures of relative hand skill (pegboard task, marking squares, and sorting matches) and relative hand strength (grip strength). The tests showed low correlations with each other $(r=0.08$ to 0.3$)$ and also differential correlations with hand preferences, indicating that different measures of relative hand skill cannot be used interchangeably. Andersen and Siebner (2018) suggest that right-left asymmetries in dexterity need to be taken into account when testing for structural correlates of preferred hand use. This relationship 
allows for the results of the present systematic review and meta-analysis on hand preference to provide some insight with regards to the prevalence of hand skill.

Moreover, only direction (e.g., right- vs. left-handedness) and not degree of hand preference (e.g., weak vs. strong handedness) was taken into account in the present metaanalyses. This distinction is an important one, as variations in the degree of hand preference, measured using a 5-item hand preference inventory, have been shown to be associated with differences in structural lateralization in somatomotor regions of the brain as well as in areas underlying high level cognitive control of action (McDowell, Felton, Vazquez, \& Chiarello, 2016). Moreover, some specific genetic polymorphisms such as in the PCSK6 gene have been associated with degree but not direction of hand preference as assessed by the EHI (Arning et al., 2013). Of note, genetic variation in PCSK6 has also been related to differences in relative hand skill (Brandler et al., 2013).

Cognitive differences have further been suggested between individuals with weak and strong hand preference (e.g., Prichard, Propper, \& Christman, 2013) or inconsistent and consistent handedness (Christman \& Prichard, 2016). Yet, most journal articles do not report a continuous score of handedness for their participants, thus not providing the data for such an analysis of degree of handedness to take place within the present study.

Alongside our main findings concerning the prevalence of handedness, this systematic review revealed that studies are not consistent with regard to the instruments they use to measure handedness or the classification scheme they employ. Moreover, there is often poor reporting of the study details as well as of the population characteristics (e.g., age). This posed a problem in the present meta-analyses, as a large number of datasets had missing information, which hindered the power of our moderating variables analysis. We suggest that study characteristics, such as instrument used to measure handedness (including 
questionnaire length and individual item content), response format, classification scheme, country in which the study took place, as well as population characteristics, such as sex, age, ancestry, and educational level of the participants, are reported in all handedness studies. Moreover, we urge researchers to report handedness for writing hand for their participants along with their EHI laterality index. These two instruments are the most popular, short, and simple and should provide a solid base for comparison among studies.

Overall, the present meta-analysis showed that left-handedness frequency approximates almost exactly to $10 \%$. Our data identify some geographical variation but we cannot confidently conclude whether this is the result of culture rather than genetics. Nevertheless, we presented some evidence suggesting that with reduction of cultural pressure, left-handedness appears to converge on a figure of $10 \%$. A more accurate picture can only be obtained with more data from under-represented ancestries.

Cultural pressures should apply specifically to hand preference for writing, which is the most universally used handedness measure. As we illustrated, this is a convenient yet crude measure which has the potential to lead to some artefacts and fluctuations especially when external social pressures are in force, for example in older generations and in specific cultural groups. These observations reinforce our recommendation of defining universal criteria for a measure of handedness. Such criteria are essential for our ability to compare effectively different studies as well as for guiding the design of future studies.

The results of our meta-analysis clearly indicate that both assessment instrument and classification scheme for handedness significantly affect handedness rates. Therefore, our findings reveal that it is vital for the progress of clinical genetic studies on handedness to adopt a universal classification of handedness definition and its assessment so that all future large scale studies will be comparable with each other. It is recommended that researchers 
would not only assess self-reported handedness and writing hand, but also include a handedness preference measure such as the EHI with categories for ambidexterity.

The present set of meta-analyses summarizes the vast field of handedness research in terms of the prevalence of hand preference in adult healthy populations. It shows in a robust way that the prevalence of left-handedness is around $10 \%$ regardless of the special features of each study, with the best overall estimate stemming from these published studies being $10.60 \%(10.40 \%$ excluding elite athletes). We claim that the same evolutionary mechanisms should apply worldwide to maintain the roughly 1:10 ratio of left- vs. right-handers found in this meta-analysis. At the same time, the exact prevalence of left-hand preference appears to be moderated by cultural factors. The moderators identified here, make for excellent candidates for future epigenetic studies. Handedness research is hindered by publication bias, p-hacking, small samples, and heterogeneity criteria. Our study clearly shows how handedness frequency is affected by assessment and definition of handedness. Our data provide a comprehensive reference for evaluating such handedness differences supporting the design and interpretation of handedness studies. We further argue that it is crucial for the field of handedness and laterality for a consensus to be reached on how handedness should be measured and classified. 


\section{References}

References marked with an asterisk (*) indicate studies included in the meta-analysis.

*Aggleton, J. P., Kentridge, R. W., \& Good, J. M. M. (1994). Handedness and musical ability: A study of professional orchestral players, composers and choir members. Psychology of Music, 22, 148-156.

*Aggleton, J. P., \& Wood, C. J. (1990). Is there a left-handed advantage in 'ballistic' sports? International Journal of Sport Psychology, 21, 46-57.

*Anakwe, R. E., Huntley, J. S., \& McEachan, J. E. (2007). Grip strength and forearm circumference in a healthy population. Journal of Hand Surgery, 32E (2), 203-209.

Andersen, K. W., \& Siebner, H. R. (2018). Mapping dexterity and handedness: recent insights and future challenges. Current opinion in behavioral sciences, 20, 123-129.

*Annett, M. (1973). Handedness in families. Annals of Human Genetics, 37(1), 93-105.

*Annett, M. (1979). Family handedness in three generations predicted by the right shift theory. Annals of Human Genetics, 42, 479-491.

*Annett, M. (1985). Left, right, hand and brain: the right shift theory. Hove, UK: Lawrence Erlbaum Associates Ltd.

Annett, M. (1999). Left-handedness as a function of sex, maternal versus paternal inheritance and report bias. Behavior Genetics, 29, 103-114.

*Annett, M. (2002). Handedness and Brain Asymmetry: the right shift theory. East Sussex: Psychology Press.

*Annett, M. (2007). Tests of the right shift genetic model for two new samples of family handedness and for the data of McKeever (2000). Laterality, 13, 105-23.

*Annett, M., \& Kilshaw, D. (1982). Mathematical ability and lateral asymmetry. Cortex, 18, 547-568. 
*Ardila, A., \& Rosselli, D. (2001). Handedness in Colombia: some associated conditions. Laterality, 6(1), 77-87.

Arning, L., Ocklenburg, S., Schulz, S., Ness, V., Gerding, W. M., Hengstler, J. G., \& Beste, C. (2013). PCSK6 VNTR polymorphism is associated with degree of handedness but not direction of handedness. PLoS ONE 8(6), e67251.

*Arning, L., Ocklenburg, S., Schulz, S., Ness, V., Gerding, W. M., Hengstler, J. G., ... Beste, C. (2015). Handedness and the X chromosome: The role of androgen receptor CAGrepeat length. Scientific Reports, 5(1991), 8325.

Asenova, I. V. (2018). Brain lateralization and developmental disorders - A new approach to unified research. London \& New York: Routledge

*Ashton, G. C. (1982). Handedness: An alternative hypothesis. Behavior Genetics, 12, 125147.

*Azémar, G., \& Stein, J. F. (1994). Surrepresentation des gauchers, en fonction de l'arme, dans l'elite mondiale de escrime. Paper presented at the Congress international de la SFPS, Poitier.

*Bakan, P., \& Putnam, W. (1974). Right-left discrimination and brain lateralization. Sex differences. Archives of Neurology, 30(4), 334-335.

*Barut, C., Ozer, C. M., Sevinc, O., Gumus, M., \& Yunten, Z. (2007). Relationships between hand and foot preferences. International Journal of Neuroscience, 117(2), 177-185.

*Beckman, L., \& Elston, R. (1962). Data on bilateral variation in man: handedness, hand clasping and arm folding in Swedes. Human Biology, 34, 99-103.

*Betancur, C., Velez, A., Cabanieu, G., LeMoal, M., \& Neveu, P. J. (1990). Association between left-handedness and allergy: a reappraisal. Neuropsychologia, 28, 223-227. 
*Birkett, P. (1981). Familial handedness and sex differences in strength of hand preference. Cortex, 17, 141-146.

Bisazza, A., Rogers, L. J., \& Vallortigara, G. (1998). The origins of cerebral asymmetry: A review of evidence of behavioural and brain lateralization in fishes, reptiles and amphibians. Neuroscience and Biobehavioral Reviews, 22(3), 411-426.

Bishop, D. V. M. (1990). Handedness and developmental disorder. Oxford: Blackwell.

Blanchard, R., \& Lippa, R. A. (2007). Birth order, sibling sex ratio, handedness, and sexual orientation of male and female participants in a BBC Internet research project. Archives of Sexual Behavior, 36, 163-176.

Borod, J. C., Herbert, S. C., \& Koff, E. (1984). Left-handers and right-handers compared on performance and preference measures of lateral dominance. British Journal of Psychology, 75, 177-186.

Brandler, W. M., Morris, A. P., Evans, D. M., Scerri, T. S., Kemp, J. P., Timpson, N. J., ... Monaco, A. P. (2013). Common variants in left/right asymmetry genes and pathways are associated with relative hand skill. PLoS genetics, 9(9), e1003751.

Brandler, W. M., \& Paracchini, S. (2014). The genetic relationship between handedness and neurodevelopmental disorders. Trends in Molecular Medicine, 20(2), 83-90.

Brain, J. L. (1977). Handedness in Tanzania: The psychological aspect. Anthropos, 72, 180192.

*Briggs, G. G., \& Nebes, R. D. (1975). Patterns of hand preference in a student population. Cortex, 11, 230-238.

*Brito, G. N., Brito, L. S., Paumgartten, F. J., \& Lins, M. F. (1989). Lateral preferences in Brazilian adults: an analysis with the Edinburgh Inventory. Cortex, 25(3), 403-415. 
*Bryden, M. P. (1977). Measuring handedness with questionnaires. Neuropsychologia, 15(45), 617-624.

*Bryden, M. P. (1989). Handedness, cerebral lateralization, and measures of 'latent lefthandedness'. International Journal of Neuroscience, 44, 227-233.

*Bryden, P. J., \& Roy, E. A. (2005). A new method of administering the Grooved Pegboard Test: Performance as a function of handedness and sex. Brain and Cognition, 58, 258268.

Buenaventura Castillo, C. E., Lynch, A. G., \& Paracchini, S. (2019). Different laterality indexes are poorly correlated with one another but consistently show the tendency of males and females to be more left- and right-lateralised, respectively. PsyArXiv, doi: https://doi.org/10.31234/osf.io/he6j2 [preprint].

*Buchtel, H. A., \& Rueckert, L. (1984). Hand posture in writing: possible artefacts from selfreport. Cortex, 20, 435-439.

*Cannon, M., Byrne, M., Cassidy, B., Larkin, C., Horgan, R., Sheppard, N. P., \& O’Callaghan, E.. (1995). Prevalence and correlates of mixed-handedness in schizophrenia. Psychiatry Research, 59(1-2), 119-125.

*Carriere, S., \& Raymond, M. (2000). Handedness and aggressive behavior in an Ntumu village in southern Cameron. Acta Ethologica, 2, 111-114.

Carson, R.G., Chua, R., Elliott, D., \& Goodman, D. (1990). The contribution of vision to asymmetries in manual aiming. Neuropsychologia, 28(11), 1215-1220.

Casey, M. B. (1996). Understanding individual differences in spatial ability within females: a nature/nurture interactionist framework. Developmental Review, 16, 241-260. 
*Casey, M. B., \& Brabeck, M. M. (1989). Exception to the male advantage on a spatial task: family handedness and college major as factors identifying women who excel. Neuropsychologia, 27, 689-696.

*Chamberlain, H. D. (1928). The inheritance of left-handedness. Journal of Heredity, 19, 557-559.

*Chapman, D., \& Walsh, R. J. (1973). Right and left dominance of hands and feet in an Australian population. Human Biology Oceania, 2(2), 167-170.

*Chapman, L. J., \& Chapman, J. P. (1987). The measurement of handedness. Brain and Cognition, 6, 175-183.

*Chen, X., Sachdev, P. S., Wen, W., \& Anstey, K. J. (2007). Sex differences in regional gray matter in healthy individuals aged $44-48$ years: A voxel-based morphometric study. NeuroImage, 36(3), 691-699.

*Chisnall, R. C. (2010). Knot-tying habits, tier handedness, and experience. Journal of Forensic Sciences, 55(5), 1232-1244.

Christman, S. D., \& Prichard, E. C. (2016). Half oaks, half willows: Degree, not direction, of handedness underlies both stable prevalence in the human population and speciesbeneficial variations in cognitive flexibility. Evolutionary Psychological Science, 2(3), 228-236.

Christman, S. D., Prichard, E. C., \& Corser, R. (2015) Factor analysis of the Edinburgh Handedness Inventory: Inconsistent handedness yields a two-factor solution. Brain and Cognition, 98, 82-86.

*Çiçek, Y., Arabaci, T., \& Çanakçi, C. F. (2010). Evaluation of oral malodour in left- and right-handed individuals. Laterality, 15(3), 317-326. 
Corballis, M. C., Hattie, J., \& Fletcher, R. (2008). Handedness and intellectual achievement: an even-handed look. Neuropsychologia, 46, 374-378.

*Coren, S. (1989). Left-handedness and accident-related injury risk. American Journal of Public Health, 79, 1040-1041.

*Coren, S. (1993). The lateral preference inventory for measurement of handedness, footedness, eyedness and earedness: norms for young adults. Bulletin of the Psychonomic Society, 31, 1-3.

*Coren, S. (1995). Family patterns in handedness: evidence for indirect inheritance mediated by birth stress. Behavior Genetics, 25, 517-524.

Coren, S., \& Halpern, D. F. (1991). Left-handedness: A marker for decreased survival fitness. Psychological Bulletin, 109, 90-106.

*Coren, S., \& Porac, C. (1979). Normative data on hand position during writing. Cortex, 15, 679-682.

*Coren, S., \& Porac, C. (1980). Birth factors and laterality: effects of birth order, parental age, and birth stress on four indices of lateral preference. Behavior Genetics, 20, 123138.

*Coren, S., Searleman, A., \& Porac, C. (1986). Rate of physical maturation and handedness. Developmental Neuropsychology, 2, 17-23.

Corey, D. M., Hurley, M. M., \& Foundas, A. L. (2001). Right and left handedness defined: A multivariate approach using hand preference and hand performance measures. Neuropsychiatry, Neuropsychology \& Behavioral Neurology. 14(3), 144-152.

*Cornell, E., \& McManus, I. C. (1992). Differential survey response rates in right- and lefthanders. British Journal of Psychology, 83, 39-43. 
*Cosenza, R. M., \& Mingoti, S. A. (1993). Career choice and handedness: a survey among university applicants. Neuropsychologia, 31, 487-497.

*Cosenza, R. M., \& Mingoti, S. A. (1995). Season of birth and handedness revisited. Perceptual and Motor Skills, 81(2), 475-480.

*Cuff, N. B. (1931). A study of eyedness and handedness. Journal of Experimental Psychology, 14, 164-175.

Cuellar Partida, G. Tung, J. Y., Eriksson, N., Albrecht, E., Aliev, F., Andreassen, O. A., ... Medland, S. E. (2019). Genome-wide association study identifies 48 common genetic variants associated with handedness. bioRxiv 831321, doi: https://doi.org/10.1101/831321 [Preprint].

*Curt, F., De Agostini, M., Maccario, J., \& Dellatolas, G. (1995). Parental hand preference and manual functional asymmetry in preschool children. Behavior Genetics, 25(6), $525-536$.

*Dane S (2019). Handedness in sub-Saharan Africans. Unpublished manuscript, Department of Physiology, Nile University of Nigeria, Abuja, Nigeria.

*Dane, S., \& Erzurumluoglu, A. (2003). Sex and handedness differences in eye-hand visual reaction times in handball players. International Journal of Neuroscience, 113, 923929.

*Dane, S., Yildirim, S., Ozan, E., Aydin, N., Oral, E., Ustaoglu, N., \& Kirpinar, I. (2009). Handedness, eyedness, and hand-eye crossed dominance in patients with schizophrenia: Sex-related lateralisation abnormalities. Laterality, 14(1), 55-65.

*Dargent-Paré, C., De Agostini, M., Mesbah, M., \& Dellatolas, G. (1992). Foot and eye preferences in adults: relationship with handedness, sex and age. Cortex, 28, 343-351. 
*De Agostini, M., Khamis, A. H., Ahui, A. M., \& Dellatolas, G. (1997). Environmental influence in preferences : an African point of view. Brain and Cognition, 35, 151-167.

Deep-Soboslay, A., Hyde, T. M., Callicott, J. P., Lener, M. S., Verchinski, B. A., Apud, J.A., ... Elvevåg, B. (2010). Handedness, heritability, neurocognition and brain asymmetry in schizophrenia, Brain, 133(10), 3113-3122.

*de Kovel, C. G. F., Carrion-Castillo, A., \& Francks, C. (2019). A large-scale population study of early life factors influencing left-handedness. Scientific Reports, 9(1), 584.

de Kovel, C.G.F., \& Francks, C. (2019).The molecular genetics of hand preference revisited. Scientific Reports, 9(1), 5986.

*de la Fuente, J., Casasanto, D., Román, A., \& Santiago, J. (2015). Can culture influence body-specific associations between space and valence? Cognitive Science, 39(4), $821-832$.

*DeLisi, L., Svetina, C., Razi, K., Shields, G., Wellman, N., \& Crow, T. (2002). Hand preference and hand skill in families with schizophrenia. Laterality, 7(4), 321-332.

Dellatolas, G., De Agostini, M., Jallon, P., Poncet, M., Rey, M., \& Lellouch, J. (1988). Mesure de la préférence manuelle par autoquestionnaire dans la population française adulte. Revue De Psychologie Appliquée, 38, 117-136.

Dellatolas, G., Tubert, P., Castresana, A., Mesbah, M., Giallonardo, T., \& Lazaratou, H., Lellouch, J. (1991). Age and cohort effects in adult handedness. Neuropsychologia, $29,255-261$.

*Demura, S., Tada, N., Matsuzawa, J., Mikami, H., Ohuchi, T., Shirane, H., ... Uchiyama, M. (2006). The Influence of Gender, Athletic Events, and Athletic Experience on the Subjective Dominant Hand and the Determination of the Dominant Hand Based on 
the Laterality Quotient (LQ) and the Validity of the LQ. Journal of Physiological Anthropology, 25(5), 321-329.

Denny, K. (2009). Handedness and depression: Evidence from a large population survey. Laterality, 14(3), 246-255.

*Dinsdale, N. L., Reddon, A. R., \& Hurd, P. L. (2011). Sex differences in the relationship between aggressiveness and the strength of handedness in humans. Laterality, 16(4), $385-400$.

*Dirnberger, G. (2012). Handedness is modulated by sex and self-perception. Laterality, $17(3), 275-286$.

Domellöf, E., Rönnqvist, L., Titran, M., Esseily, R., \& Fagard, J. (2009). Atypical functional lateralization in children with fetal alcohol syndrome. Developmental Psychology, 51, 696-705.

*Downey, J.E. (1927). Types of dextrality and their implications. American Journal of Psychology, 38, 317-367.

Dragovic, M., \& Hammond, G. (2005). Handedness in schizophrenia: A quantitative review of evidence. Acta Psychiatrica Scandinavica, 111(6), 1-10.

*Dragovic, M., Milenkovic, S., \& Hammond, G. (2008). The distribution of hand preference is discrete: A taxometric examination. British Journal of Psychology, 99(4), 445-459.

*Dronamraju, K. R. (1975). Frequency of left-handedness among the Andhra Pradesh people. Acta Geneticae Medicae et Gemellologiae (Roma), 24(1-2), 161-162.

Duval, S., \& Tweedie, R. (2000). A nonparametric 'trim and fill' method of accounting for publication bias in meta-analysis. Journal of the American Statistical Association, 95, 89-99. 
*Elalmis, D. D., \& Tan, Ü. (2005). Hand preference in a Turkish population. International Journal of Neuroscience, 115(5), 705-712.

*Elalmis, D. D., \& Tan, Ü. (2008). Dynamics of manual skill: A computerized analysis of single peg movements and stochastic resonance hypothesis of cerebral laterality. International Journal of Neuroscience, 118(3), 399-432.

*Elias, L. J., Saucier, D. M., \& Guylee, M. J. (2001). Handedness and depression in university students: a sex by handedness interaction. Brain and Cognition, 46(1-2), 125-129.

*Ellis, S. J., Ellis, P. J., \& Marshall, E. (1988). Hand preference in a normal population. Neuropsychologia, 24, 157-163.

*Elneel, F. H. F., Carter, F., Tang, B., \& Cuschieri, A. (2008). Extent of innate dexterity and ambidexterity across handedness and gender: Implications for training in laparoscopic surgery. Surgical Endoscopy and Other Interventional Techniques, 22(1), 31-37.

*Espírito-Santo, H., Pires, C. F., Garcia, I. Q., Daniel, F., Silva, A. G. da, \& Fazio, R. L. (2017). Preliminary validation of the Portuguese Edinburgh Handedness Inventory in an adult sample. Applied Neuropsychology: Adult, 24(3), 275-287.

*Fagard, J., Chapelain, A., \& Bonnet, P. (2015). How should 'ambidexterity' be estimated? Laterality, 20(5), 543-570.

Fagard, J., \& Dahmen, R. (2004). Cultural influences on the development of lateral preferences: A comparison between French and Tunisian children. Laterality, 9(1), $67-78$.

*Faurie, C., Bonenfant, S., Goldberg, M., Hercberg, S., Zins, M., \& Raymond, M. (2008). Socio-economic status and handedness in two large cohorts of French adults. British Journal of Psychology, 99(4), 533-554. 
Fisher, Z., \& Tipton, E. (2015). robumeta: An R-package for robust variance estimation in meta-analysis. arXiv Preprint arXiv: 1503.02220.

Fleminger, J. J., Dalton, R., \& Standage, K. J. (1977). Age as a factor in the handedness of adults. Neuropsychologia, 15 (3), 471-473.

Frayer, D. W., Clarke, R. J. , Fiore, I. , Blumenschine, R. J., Pérez-Pérez, A., Martinez, L. M., ... Bondioli, L. (2016). OH-65: The earliest evidence for right-handedness in the fossil record. Journal of Human Evolution, 100, 65-72.

*Fry, C. J. (1990). Left-handedness: association with college major, familial sinistrality, allergies, and asthma. Psychological Reports, 67, 419-433.

*Genetta-Wadley, A., \& Swirsky-Sacchetti, T. (1990). Sex differences and handedness in hemispheric lateralization of tactile-spatial functions. Perceptual and Motor Skills, $70(2), 579-590$.

Geschwind, N., \& Galaburda, A. S. (1987). Cerebral lateralization: Biological mechanisms, associations, and pathology. Cambridge, MA: MIT Press.

*Gilbert, A. N., \& Wysocki, C. J. (1992). Hand preference and age in the United States. Neuropsychologia, 30, 601-608.

*Gladue, B. A., \& Bailey, J. M. (1995). Spatial ability, handedness, and human sexual orientation. Psychoneuroendocrinology, 20(5), 487-497.

*Götestam, K. R. (1990). Left handedness among students of architecture and music. Perceptual and Motor Skills, 70, 1323-1327.

*Green, R., \& Young, R. (2001). Hand preference, sexual preference, and transsexualism. Archives of Sexual Behaviour, 30(6), 565-574. 
*Grouios, G., Tsorbatzoudis, H., Alexandris, K., \& Brakoulis, V. (2000). Do left-handed competitors have an innate superiority in sports? Perceptual and Motor Skills, 90, $1273-1282$.

*Gunstad, J., Spitznagel, M. B., Luyster, F., Cohen, R. A., \& Paul, R. H. (2007). Handedness and cognition across the healthy lifespan. International Journal of Neuroscience, $117(4), 477-485$.

Güntürkün, O., \& Ocklenburg, S. (2017). Ontogenesis of lateralization. Neuron, 94(2), 249263.

*Gupta, N., Sanyal, S., \& Babbar, R. (2008). Sensory nerve conduction velocity is greater in left handed persons. Indian Journal of Physiology and Pharmacology, 52(2), 189192.

*Gur, R. E., \& Gur, R. C. (1977). Sex differences in the relations among handedness, sighting-dominance and eye -acuity. Neuropsychologia, 15, 585-590.

Gureje, O. (1988). Sensorimotor laterality in schizophrenia: which features transcend cultural influences? Acta Psychiatrica Scandinavica, 77(2), 188-193.

*Halpern, D. F., Haviland, M. G., \& Killian, C. D. (1998). Handedness and sex differences in intelligence: evidence from the medical college admission test. Brain and Cognition, $38(1), 87-101$.

*Hannay, H. J., Ciaccia, P. J., Kerr, J. W., \& Barrett, D. (1990). Self-report of right-left confusion in college men and women. Perceptual and Motor Skills, 70(2), 451-457.

*Hannula, S., Bloigu, R., Majamaa, K., Sorri, M., \& Mäki-Torkko, E. (2012). Ear diseases and other risk factors for hearing impairment among adults: An epidemiological study. International Journal of Audiology, 51(11), 833-840. 
*Harburg, E., Feldstein, A., \& Papsdorf, J. (1978). Handedness and smoking. Perceptual and Motor Skills, 47(3 Pt 2), 1171-1174.

*Harburg, E., Roeper, P., Ozgoren, F., \& Feldstein, A. N. (1981). Handedness and temperament. Perceptual and Motor Skills, 52, 283-290.

Hardyck, C., Goldman, R., \& Petrinovich, L. (1975). Handedness and sex, race and age. Human Biology, 47, 369-375.

*Harris, L. J., \& Gitterman, S. R. (1978). University professors' self-descriptions of left-right confusability: sex and handedness differences. Perceptual and Motor Skills, 47(3), 819-823.

*Harvey, T. J. (1988). Science and handedness. British Journal of Educational Psychology, 58 (Pt 2), 201-204.

*Hatta, T., \& Kawakami, A. (1995). Patterns of handedness in modern Japanese: a cohort effect shown by re-administration of the H.N. Handedness Inventory after 20 years. Canadian Journal of Experimental Psychology, 49(4), 505-512.

*Hatta, T., \& Nakatsuka, Z. (1976). Note on hand preference of Japanese people. Perceptual and Motor Skills, 42(2), 530.

Hausmann, M. (2017). Why sex hormones matter for neuroscience: A very short review on sex, sex hormones, and functional brain asymmetries. Journal of Neuroscience Research, 95(1-2), 40-49.

Heikkilä, K., Van Beijsterveldt, C. E. M., Haukka, J., Iivanainen, M., Saari-Kemppainen, A., Silventoinen, K., ... Vuoksimaa, E. (2018). Triplets, birthweight, and handedness. Proceedings of the National Academy of Sciences, 115(23), 6076-6081.

*Heikkilä, K., Vuoksimaa, E., Saari-Kemppainen, A., Kaprio, J., Rose, R. J., Haukka, J., ... Iivanainen, M. (2015). Higher prevalence of left-handedness in twins? Not after 
controlling birth time confounders. Twin Research and Human Genetics, 18(5), 526532.

*Heim, A. W., \& Watts, K. P. (1976). Handedness and cognitive bias. Quarterly Journal of Experimental Psychology, 28, 355-360.

*Hicks, R. A., Dusek, C., Larsen, F., \& Pellegrini, R. J. (1980). Reliability of seasonal variation in births of left-handed women. Perceptual and Motor Skills, 50(1), 81-82.

*Hicks, R. A., Pellegrini, R. J., \& Evans, E. A. (1978). Handedness and birth risk. Neuropsychologia, 16(2), 243-245.

*Hicks, R. E., \& Kinsbourne, M. (1976). Human handedness: a partial cross-fostering study. Science, 192, 908-910.

Higgins, J. P. T., Thompson, S. G., Deeks, J. J., \& Altman, D. (2003). Measuring inconsistency in meta-analyses. $B M J, 327,557-560$.

Hirnstein, M., \& Hugdahl, K. (2014). Excess of non-right-handedness in schizophrenia: Meta-analysis of gender effects and potential biases in handedness assessment. British Journal of Psychiatry, 205(4), 260-267.

*Holder, M. K. (1992). Hand preference Questionnaires: one gets what one asks for. Unpublished Masters of Philosophy Thesis, Rutger University, New Jersey, New York.

*Holtzen, D. W. (1994). Handedness and sexual orientation. Journal of Clinical and Experimental Neuropsychology, 16, 702-712.

*Holtzen, D. W. (2000). Handedness and professional tennis. International Journal of Neuroscience, 105, 101-119. 
*Hoogmartens, M. J., \& Caubergh, M. A. (1987). Chewing side preference in man correlated with handedness, footedness, eyedness and earedness. Electomyography and Clinical Neurophysiology, 27, 293-300.

*Hoosain, R. (1990). Left-handedness and handedness switch amongst the Chinese. Cortex, $26,451-454$.

*Huang, H., \& Sejdić, E. (2013). Assessment of resting-state blood flow through anterior cerebral arteries using transcranial Doppler recordings. Ultrasound in Medicine and Biology, 39(12), 2285-2294.

Hugdahl, K., Satz, P., Mitrushina, M., \& Miller, E.N. (1993). Left-handedness and old age: do left-handers die earlier? Neuropsychologia, 31, 325-333.

Hujoel, P. P. (2018). Breastfeeding and handedness: A systematic review and meta-analysis of individual participant data. Laterality, 1-18.

Hung, C.-C., Tu, Y.-K., Chen, S.-H., \& Chen, R.-C. (1985). A study on handedness and cerebral speech dominance in right-handed Chinese. Journal of Neurolinguistics, 1, 143-163.

*Ida, Y., \& Bryden, M. P. (1996). A comparison of hand preference in Japan and Canada. Canadian Journal of Experimental Psychology, 50, 234-239.

*Inglis, J., \& Lawson, J. S. (1984). Handedness, sex and intelligence. Cortex, 20(3), 447-451.

*Iwasaki, S., Kaiho, T., \& Iseki, K. (1995). Handedness trends across age groups in a Japanese sample of 2316. Perceptual and Motor Skills, 80, 979-994.

Jones, G. V., \& Martin, M. (2000). A note on Corballis (1997) and the genetics and evolution of handedness: Developing a unified distributional model from the sex-chromosomes gene hypothesis. Psychological Review, 107(1), 213-218.

Jones, G. V., \& Martin, M. (2008). Seasonal anisotropy in handedness. Cortex, 44, 8-12. 
*Jung, H. S., \& Jung, H. S. (2009). Hand dominance and hand use behaviour reported in a survey of 2437 Koreans. Ergonomics, 52(11), 1362-1371.

*Kalaycıŏlu, C., Kara, C., Atbaşoğlu, C., \& Nalçac1, E. (2008). Aspects of foot preference: Differential relationships of skilled and unskilled foot movements with motor asymmetry. Laterality, 13(2), 124-142.

*Kalichman, L., Korostishevsky, M., \& Kobyliansky, E. (2008). Laterality indices in the Chuvashian population. Anthropologischer Anzeiger, 66(4), 409-418.

Kalisch, T., Wilimzig, C., Kleibel, N., Tegenthoff, M., \& Dinse, H. R. (2006). Age-related attenuation of dominant hand superiority. PLoS ONE 1(1), e90.

Kang, Y., \& Harris, L. J. (1996). Accuracy of college students' reports of parental handedness. Laterality, 1, 269-279.

*Kauranen, K., \& Vanharanta, H. (1996). Influences of aging, gender, and handedness on motor performance of upper and lower extremities. Perceptual and Motor Skills, $82(2), 515-525$.

Klöppel, S., Mangin, J. F., Vongerichten, A., Frackowiak, R. S., \& Siebner, H. R. (2010). Nurture versus nature: long-term impact of forced right-handedness on structure of pericentral cortex and basal ganglia. Journal of Neuroscience, 30(9), 3271-3275.

*Klum, M., Wolf, M. B., Hahn, P., Leclère, F. M., Bruckner, T., \& Unglaub, F. (2012). Normative data on wrist function. Journal of Hand Surgery, 37(10), 2050-2060.

Knecht, S., Dräger, B., Deppe, M., Bobe, L., Lolmann, H., Flöel, A., ... Henningsen, H. (2000). Handedness and hemispheric language dominance in healthy humans. Brain, $123,2512-2518$.

Komai, T., \& Fukuoka, G. (1934). A study on the frequency of left-handedness and leftfootedness among Japanese school children. Human Biology, 6, 33-42. 
*Kuderer, S., \& Kirchengast, S. (2016). The association of hand preference and sensation seeking behavior. Anthropologischer Anzeiger, 73(3), 187-194.

Kushner, H. I. (2013). Why are there (almost) no left-handers in China? Endeavour, 37, 7181.

*Lai, A., Serra, M., Petretto, D. R., Masala, C., \& Preti, A. (2014). Patterns of hand preference in Italian adolescent high-school students. Laterality, 19(6), 718-744.

Lake, D. A., \& Bryden, M. P. (1976). Handedness and sex differences in hemispheric asymmetry. Brain and Language, 3(2), 266-282.

Laland, K. N. (2008). Exploring gene-culture interactions: insights from handedness, sexual selection and niche-construction case studies. Philosophical Transactions of the Royal Society B: Biological Sciences, 363(1509), 3577-3589.

Laland, K. N., Kumm, J., Van Horn, J. D., \& Feldman, M. W. (1995). A gene-culture model of human handedness. Behavior Genetics, 25(5), 433-445.

Lalumiere, M. L., Blanchard, R., \& Zucker, K. J. (2000). Sexual orientation and handedness in men and women: a meta-analysis. Psychological Bulletin, 126(4), 575-592.

*Lambert, A., \& Hallett, C. (2009). Hand preference for sending mobile-phone text messages: Associations with sex, writing hand, and throwing hand. Laterality, 14(4), $329-344$.

*Lansky, L. M., Feinstein, H., \& Peterson, J. M. (1988). Demography of handedness in two samples of randomly selected adults $(\mathrm{N}=2083)$. Neuropsychologia, 26, 465-477.

*Lee-Feldstein, A., \& Harburg, E. (1982). Alcohol use among right- and left-handed persons in a small community. Journal of Studies on Alcohol, 43(7), 824-829.

*Leiber, L., \& Axelrod, S. (1981). Not all sinistrality is pathological. Cortex, 17, 259-272. 
*Lester, D., Werling, N., \& Heinle, N. H. (1982). Graphoanalytic differences by sex and handedness. Perceptual and Motor Skills, 55(3 Pt 2), 1190.

*Levander, M., \& Schalling, D. (1988). Hand preference in a population of Swedish college students. Cortex, 24, 149-156.

Liederman, J., \& Healy, J. M. (1986). Independent dimensions of hand preference: reliability of the factor structure and the handedness inventory. Archives of Clinical Neuropsychology, 1, 371-386.

*Lien, Y. J., Chen, W. J., Hsiao, P. C., \& Tsuang, H. C. (2015). Estimation of heritability for varied indexes of handedness. Laterality, 20(4), 469-482.

*Lippa, R. A. (2003). Handedness, sexual orientation, and gender-related personality traits in men and women. Archives of Sexual Behaviour, 32(2), 103-114.

*Loffing, F. (2017). Left-handedness and time pressure in elite interactive ball games. Biology Letters, 13(11), 10-13.

Loffing, F., \& Hagemann, N. (2012). Side bias in human performance: A review on the lefthanders' advantage in sports. In T. Dutta, M. Mandal, \& S. Kumar, (Eds.),. Bias in Human Behaviour (pp. 163-182). Hauppauge, NY: Nova Science.

Loffing, F., \& Hagemann, N. (2016). Performance differences between left- and right-sided athletes in one-on-one interactive sports. In F. Loffing, N. Hagemann, B. Strauss, \& C. MacMahon (Eds.), Laterality in sports: theories and applications (pp. 249-277). San Diego, CA: Academic Press.

*Loffing, F., Sölter, F., \& Hagemann, N. (2014). Left preference for sport tasks does not necessarily indicate left-handedness: Sport-specific lateral preferences, relationship with handedness and implications for laterality research in behavioural sciences. PLoS ONE, 9(8). 
*Lui, D. F., Baker, J. F., Nfila, G., Perera, A., \& Stephens, M. (2012). Hand dominance in orthopaedic surgeons. Acta Orthopaedica Belgica, 78(4), 531-537.

*Lyle, K. B., Chapman, L. K., \& Hatton, J. M. (2013). Is handedness related to anxiety? New answers to an old question. Laterality, 18(5), 520-535.

*Maehara, K., Negishi, N., Tsai, A., Iizuka, R., Otsuki, N., Suzuki, S., ... Sumiyoshi, Y. (1988). Handedness in the Japanese. Developmental Neuropsychology, 4, 117-127.

*Marchant-Haycox, S. E., McManus, I. C., \& Wilson, G. D. (1991). Left-handedness, homosexuality, HIV infection and AIDS. Cortex, 27, 45-56.

Markou, P., Ahtam, B., \& Papadatou-Pastou, M. (2017). Elevated Levels of Atypical Handedness in Autism: Meta-Analyses. Neuropsychology Review, 27(3), 258-283.

*Marmolejo-Ramos, F., Correa, J. C., Sakarkar, G., Ngo, G., Ruiz-Fernández, S., Butcher, N., \& Yamada, Y. (2017). Placing joy, surprise and sadness in space: a crosslinguistic study. Psychological Research, 81(4), 750-763.

Martin, M., \& Jones, G. V. (1999). Handedness and season of birth: A gender-invariant relation. Cortex, 35, 123-128.

Martin, M., Papadatou-Pastou, M., Jones, G. V., \& Munafò, M. R. (2010). Sex and location as determinants of handedness: reply to Vuoksimaa and Kaprio (2010). Psychological Bulletin, 136(3), 348-350.

*Martin, W. L. B., \& Porac, C. (2007). Patterns of handedness and footedness in switched and non-switched Brazilian left-handers: cultural effects on the development of lateral preferences. Developmental Neuropsychology, 31(2), 159-179.

*Mascie-Taylor, C. G. N. (1980). Hand preference and components of IQ. Annual Human Biology, 7(3), 235-248. 
*Mascie-Taylor, C. G. N., MacLarnon, A. M., Lanigan, P. M., \& McManus, I. C. (1981). Foot-length asymmetry, sex, and handedness. Science, 212(4501), 1416-1419.

Maxwell, S. E., Lau, M. Y., \& Howard, G. S. (2015). Is psychology suffering from a replication crisis? What does "failure to replicate" really mean? American Psychologist, 70, 487-498.

Mazoyer, B., Zago, L., Jobard, G., Crivello, F., Joliot, M., Perchey, G., ... Tzourio-Mazoyer, N. (2014). Gaussian mixture modeling of hemispheric lateralization for language in a large sample of healthy individuals balanced for handedness. PloS one, 9(6), e101165.

McDowell, A., Felton, A., Vazquez, D., \& Chiarello, C. (2016). Neurostructural correlates of consistent and weak handedness. Laterality, 21(4-6), 348-370.

*McFarland, K., \& Anderson, J. (1980). Factor stability of the Edinburgh Handedness Inventory as a function of test-retest performance, age and sex. British Journal of Psychology, 71, 135-142.

*McGee, M. G. (1976). Laterality, hand preference and human spatial ability. Perceptual and Motor Skills, 42, 781-782.

*McGee, M. G., \& Cozad, T. (1980). Population genetic analysis of human hand preference: Evidence for generation differences, familial resemblance and maternal effects. Behavior Genetics, 10, 263-275.

*McKeever, W. F., \& Rich, D. A. (1990). Left handedness and immune disorders. Cortex, $26(1), 33-40$.

McManus, I. C. (1984). Genetics of handedness in relation to language disorder. Advances in Neurology, 42, 125-138.

*McManus, I. C. (1986). Book review: 'Left side, right side: A review of laterality research' (Beaton, A.). British Journal of Psychology, 77, 419-421. 
McManus, I. C. (2002). Right Hand, Left Hand. London: Weidenfeld \& Nicolson.

McManus, I.C. (2009). The history and geography of human handedness. In I. E. C. Sommer, \& R. S. Kahn (Eds.), Language Lateralization and Psychosis (pp. 37-58). Cambridge: Cambridge University Press.

McManus, I.C. (2010). Precisely wrong? The problems with the Jones and Martin genetic model of sex differences in handedness and language lateralisation. Cortex, 700-702.

*McManus, I. C. (2019, June 24). The incidence of left-handedness: a meta-analysis [1993]. https://doi.org/10.31234/osf.io/bsnhd

McManus, I. C., \& Bryden, M. P. (1992). The genetics of handedness, cerebral dominance and lateralization. In I. Rapin \& S. J. Segalowitz (Eds.), Handbook of neuropsychology Vol.6: Child neuropsychology (pp. 115-142). Amsterdam: Elsevier.

McManus, I. C., Davison, A., \& Armour, J. A. (2013). The evolution of human handedness. Annals of the New York Academy of Sciences, 1288(1), 48.

McManus, I. C., \& Hartigan, A. (2007). Declining left-handedness in Victorian England seen in the films of Mitchell and Kenyon. Current Biology, 17(18), R793-R794.

McManus, I. C., Moore, J., Freegard, M., \& Rawles, R. (2010). Science in the Making: Right Hand, Left Hand. III: Estimating historical rates of left-handedness. Laterality, 15(12), $186-208$.

McManus, I. C., Murray, B., Doyle, K., \& Baron-Cohen, S. (1992). Handedness in childhood autism shows a dissociation of skill and preference. Cortex, 28, 373-381.

Medland, S. E., Duffy, D. L., Spurdle, A. B., Wright, M. J., Geffen, G. M., Montgomery, G. W., \& Martin, N. G. (2005). Opposite effects of androgen receptor CAG repeat length on increased risk of left-handedness in males and females. Behavior Genetics, 35(6), 735-744. 
Medland, S. E., Duffy, D. L., Wright, M. J., Geffen, G. M., Hay, D. A., Levy, F., ... Boomsma, D. I. (2009). Genetic influences on handedness: Data from 25,732 Australian and Dutch twin families. Neuropsychologia, 47(2), 330-337.

*Merrell, D. J. (1957). Dominance of eye and hand. Human Biology, 29, 314-328.

*Mészáros, S., Ferencz, V., Csupor, E., Mester, A., Hosszú, E., Tóth, E., \& Horváth, C. (2006). Comparison of the femoral neck bone density, quantitative ultrasound and bone density of the heel between dominant and non-dominant side. European Journal of Radiology, 60(2), 293-298.

*Milenković, S., Brkić, M., \& Belojević, G. (2013). Left-handedness and neurotic disturbances in adult urban population. Srpski Arhiv Za Celokupno Lekarstvo, 141(11-12), 785-788.

Moffat, S. D., \& Hampson, E. (1996). Salivary testosterone levels in left- and right-handed adults. Neuropsychologia, 34(3), 225-233.

Moher, D., Liberati, A., Tetzlaff, J., Altman, D. G., \& The PRISMA Group. (2009). Preferred reporting items for systematic reviews and meta-analyses: The PRISMA statement. PLoS Medicine, 6(6), e1000097.

*Morley, R., \& Caffrey, E. A. (1994). Handedness in blood donors: no association with blood group or twinning. Cortex, 30, 707-710.

*Mustanski, B. S., Bailey, J. M., \& Kaspar, S. (2002). Dermatoglyphics, handedness, sex, and sexual orientation. Archives of Sexual Behaviour, 31(1), 113-122.

*Nalçaci, E., Kalaycioğlu, C., Çiçek, M., \& Genç, Y. (2001). The relationship between handedness and fine motor performance. Cortex, 37(4), 493-500. 
*Narr, K. L., Bilder, R. M., Luders, E., Thompson, P. M., Woods, R. P., Robinson, D., ... Toga, A. W. (2007). Asymmetries of cortical shape: Effects of handedness, sex, and schizophrenia. NeuroImage, 34 (3), 939-948.

*Newcombe, F., \& Ratcliff, G. (1973). Handedness, speech lateralization and ability. Neuropsychologia, 11(4), 399-407.

*Newcombe, F. C., Ratcliff, G. G., Carrivick, P. J., Hiorns, R. W., Harrison, G. A., \& Gibson, J. B. (1975). Hand preference and I.Q. in a group of Oxfordshire villages. Annals of Human Biology, 2, 235-242.

*Nicholls, M. E. R., Chapman, H. L., Loetscher, T., \& Grimshaw, G. M. (2010). The relationship between hand preference, hand performance, and general cognitive ability. Journal of the International Neuropsychological Society, 16(4), 585-592.

*Nicholls, M. E. R., Orr, C. A., Yates, M. J., \& Loftus, A. M. (2008). A new means of measuring index/ring finger (2D:4D) ratio and its association with gender and hand preference. Laterality, 13(1), 71-91.

*Nicholls, M. E. R., Thomas, N. A., Loetscher, T., \& Grimshaw, G. M. (2013). The flinders handedness survey (FLANDERS): A brief measure of skilled hand preference. Cortex, 49(10), 2914-2926.

Noroozian, M., Lofti, J., Gassemzadeh, H., Emami, H., \& Mehrabi, Y. (2002). Academic achievement and learning abilities in left-handers: Guilt or gift? Cortex, 38, 779-785.

Ntolka, E., \& Papadatou-Pastou, M. (2018). Right-handers have negligibly higher IQ scores than left-handers: Systematic review and meta-analyses. Neuroscience and Biobehavioral Reviews, 84, 376-393. 
*Obrzut, J. E., Dalby, P. R., Boliek, C. A., \& Cannon, G. E. (1992). Factorial structure of the Waterloo Handedness Questionnaire for control and learning-disabled adults. Journal of Clinical and Experimental Neuropsychology, 14(6), 935-950.

Ocklenburg, S., Isparta, S., Peterburs, J., \& Papadatou-Pastou, M. (2019). Paw preferences in cats and dogs: Meta-analysis. Laterality, 24, 647-677

Ocklenburg, S., Schmitz, J., Moinfar, Z., Moser, D., Klose, R., Lor, S., ... Güntürkün, O. (2017). Epigenetic regulation of lateralized fetal spinal gene expression underlies hemispheric asymmetries. Elife, 6, e22784.

*Ocklenburg, S., Ströckens, F., Bless, J. J., Hugdahl, K., Westerhausen, R., \& Manns, M. (2016). Investigating heritability of laterality and cognitive control in speech perception. Brain and Cognition, 109, 34-39.

*Ofte, S. H. (2002). Right-left discrimination: effects of handedness and educational background. Scandinavian Journal of Psychology, 43(3), 213-219.

*Oldfield, R. C. (1971). The assessment and analysis of handedness: the Edinburgh inventory. Neuropsychologia, 9(1), 97-113.

Open Science Collaboration. (2015). Estimating the reproducibility of psychological science. Science, 349(6251), aac4716.

*Overby, L. A. (1994). The relationship of handedness to depression in male and female college students. Personality and Individual Differences, 16(4), 537-541.

Papadatou-Pastou, M. (2018). Handedness and cognitive ability: Using meta-analysis to make sense of the data. Progress in Brain Research, 238, 179-206.

Papadatou-Pastou, M., Martin, M., \& Mohr, C. (2017). Salivary testosterone levels are unrelated to handedness or cerebral lateralization for language. Laterality, 22(2), 123156. 
Papadatou-Pastou, M., Martin, M., \& Munafò, M. R. (2013). Measuring hand preference: A comparison among different response formats using a selected sample, Laterality, 18(1), 68-107.

Papadatou-Pastou, M., Martin, M., Munafò, M. R., \& Jones, G. V. (2008). Sex differences in left-handedness: A meta-analysis of 144 studies. Psychological Bulletin, 134(5), $677-$ 699.

Papadatou-Pastou, M., \& Sáfár, A. (2016). Handedness prevalence in the deaf: Metaanalyses. Neuroscience and Biobehavioral Reviews, 60, 98-114.

Papadatou-Pastou, M., \& Tomprou, D. M. (2015). Intelligence and handedness: Metaanalyses of studies on intellectually disabled, typically developing, and gifted individuals. Neuroscience \& Biobehavioral Reviews, 56, 151-165.

*Perelle, I. B., \& Ehrman, L. (1983). The development of laterality. Behavioral Science, 28, 284-310.

*Perelle, I. B., \& Ehrman, L. (1994). An international study of human handedness: the data. Behavioral Genetics, 24(3), 217-227.

Peters, M. (1992). How sensitive are handedness prevalence figures to differences in questionnaire classification procedures? Brain and Cognition, 18, 208-215.

*Peters, M., Petrie, B., \& Oddie, D. (1981). Foot-length asymmetry, sex and handedness. Science, 212, 1417-1418.

*Peters, M., Reimers, S., \& Manning, J. T. (2006). Hand preference for writing and associations with selected demographic and behavioral variables in 255,100 subjects: The BBC internet study. Brain and Cognition, 62(2), 177-189.

*Plato, C. C., Fox, K. M., \& Garruto, R. M. (1984). Measures of lateral functional dominance: hand dominance. Human Biology, 56, 259-275. 
*Porac, C. (1993). Are age trends in adult hand preference best explained by developmental shifts or generational differences. Canadian Journal of Experimental Psychology, 47, $697-713$.

Porac, C., \& Coren, S. (1981). Lateral preferences and human behavior. Berlin: Springer Verlag.

*Porac, C., Coren, S., \& Searleman, A. (1983). Inverted versus straight handwriting posture: a family study. Behavior Genetics, 13, 311-320.

Porac, C., Rees, L., \& Buller, T. (1990). Switching hands: A place for left hand use in a right hand world. Advances in Psychology, 67(C), 259-290.

*Porfert, A. R., \& Rosenfield, D. B. (1978). Prevalence of stuttering. Journal Neurology, Neurosurgery and Psychiatry, 41(10), 954-956.

*Preti, A., Sisti, D., Rocchi, M. B., Busca, M., Vellante, M., Camboni, M. V., ... Masala, C. (2011). Male Female Differences in Left-Handedness in Sardinia, Italy. Laterality, 16(6), 737-752.

*Preti, A., Usai, I., Pintus, E., Sardu, C., Petretto, D. R., \& Masala, C. (2012). Lefthandedness is statistically linked to lifetime experimentation with illicit drugs. Laterality, 17(3), 318-339.

Prichard, E., Propper, R. E., \& Christman, S. D. (2013). Degree of handedness, but not direction, is a systematic predictor of cognitive performance. Frontiers in Psychology, $4,9$.

Priddle, T. H., \& Crow, T. J. (2013). The protocadherin 11X/Y (PCDH11X/Y) gene pair as determinant of cerebral asymmetry in modern Homo sapiens. Annals of the New York Academy of Sciences, 1288(1), 36-47. 
Provins, K. A., Milner, A. D., \& Kerr, P. (1982). Asymmetry of manual preference and performance. Perceptual and Motor Skills, 54, 179-194.

Ratnu, V. S., Emami, M. R., \& Bredy, T. W. (2017). Genetic and epigenetic factors underlying sex differences in the regulation of gene expression in the brain. Journal of Neuroscience Research, 95(1-2), 301-310.

*Ravichandran, C., Shinn, A. K., Öngür, D., Perlis, R. H., \& Cohen, B. (2017). Frequency of non-right-handedness in bipolar disorder and schizophrenia. Psychiatry Research, 253, 267-269.

Raymond, M., \& Pontier, D. (2004). Is there geographical variation in human handedness? Laterality, 9(1), 35-51.

*Raymond, M., Pontier, D., Dufour, A.-B., \& Moller, A. P. (1996). Frequency-dependent maintenance of left handedness in humans. Proceedings of the Royal Society of London, B, 206, 1627-1633.

*Reina, N., Cavaignac, E., Trousdale, W. H., Laffosse, J. M., \& Braga, J. (2017). Laterality and grip strength influence hand bone micro-architecture in modern humans, an HRpQCT study. Journal of Anatomy, 230(6), 796-804.

*Reiss, M., \& Reiss, G. (1997). Lateral preferences in a German population. Perceptual and Motor Skills, 85(2), 569-574.

*Reiss, M., Reiss, G., \& Freye, H. A. (1998). Some aspects of self-reported hand preference. Perceptual and Motor Skills, 86(3 Pt 1), 953-954.

*Rife, D. C. (1940). Handedness with special reference to twins. Genetics, 25, 178-186.

*Risch, N., \& Pringle, G. (1985). Segregation analysis of human hand preference. Behavior Genetics, 15, 385-400. 
*Robinson, K. J., Hurd, P. L., Read, S., \& Crespi, B. J. (2016). The PCSK6 gene is associated with handedness, the autism spectrum, and magical ideation in a nonclinical population. Neuropsychologia, 84, 205-212.

Rogers, L. J. (2008). Development and function of lateralization in the avian brain. Brain Research Bulletin, 76(3), 235-244.

*Rosenstein, L. D., \& Bigler, E. D. (1987). No relationship between handedness and sexual preference. Psychological Reports, 60(3 Pt 1), 704-706.

*Sakano, N., \& Pickenhain, L. (1985). Japanese and German data on the correlation between handedness, arm folding and hand clasping. Studia Psychologica, 27, 107-116.

*Salmaso, D., \& Longoni, A. M. (1985). Problems in the assessment of hand preference. Cortex, 21, 533-549.

*Sanders, B., Wilson, J. R., \& Vandenberg, S. G. (1982). Handedness and spatial ability. Cortex, 18, 79-90.

*Saunders, D. A., \& Campbell, A. L. (1985). Handedness prevalence in a population of black university students. Perceptual and Motor Skills, 60(2), 355-360.

*Savel, S. (2009). Individual differences and left/right asymmetries in auditory space perception. I. Localization of low-frequency sounds in free field. Hearing Research, 255(1-2), 142-154.

Schaafsma, S. M., Riedstra, B. J., Pfannkuche, K. A., Bouma, A., \& Groothuis, T. G. G. (2009). Epigenesis of behavioural lateralization in humans and other animals. Philosophical Transactions of the Royal Society B: Biological Sciences, 364(1519), $915-927$.

*Schachter, S. C., Ransil, B. J., \& Geschwind, N. (1987). Associations of handedness with hair color and learning disabilities. Neuropsychologia, 25(1B), 269-276. 
Schmitz, J., Kumsta, R., Moser, D., Güntürkün, O., \& Ocklenburg, S. (2018). DNA methylation in candidate genes for handedness predicts handedness direction. Laterality, 23(4), 441-461.

Schmitz, J., Metz, G. A., Güntürkün, O., \& Ocklenburg, S. (2017). Beyond the genomeTowards an epigenetic understanding of handedness ontogenesis. Progress in Neurobiology, 159, 69-89.

*Searleman, A., \& Fugagli, A. K. (1987). Suspected autoimmune disorders and lefthandedness: evidence form individuals with diabetes, Crohn's disease and ulcerative colitis. Neuropsychologia, 25, 367-374.

*Searleman, A., Porac, C., \& Coren, S. (1984). Writing hand posture and four indexes of lateral preference. Brain and Cognition, 3(1), 86-93.

*Searleman, A., Tweedy, J., \& Springer, S. P. (1979). Interrelationships among subject variables believed to predict cerebral organization. Brain and Language, 7(3), 267276.

*Segal, N. L. (1984). Distribution of handedness among an academically select group of high school and university students. Journal of General Psychology, 111, 79-82.

*Shan-Ming, Y., Flor-Henry, P., Dayi, C., Tiangi, L., Shuguang, Q., \& Zenxiang, M. (1985). Imbalance of hemispheric functions in the major psychoses: A study of handedness in the People's Republic of China. Biological Psychiatry, 20, 906-917.

*Sherman, J. (1979). Cognitive performance as a function of sex and handedness: An evaluation of the Levy hypothesis. Psychology of Women Quarterly, 3, 378-390.

*Shettel-Neuber, J., \& O'Reilly, J. (1983). Handedness and career choice: Another look at supposed left/right differences. Perceptual and Motor Skills, 57, 391-397. 
*Shimizu, A., \& Endo, M. (1983). Handedness and familial sinistrality in a Japanese student population. Cortex, 19, 265-272.

Sicotte, N. L., Woods, R. P., \& Mazziotta, J. C. (1999). Handedness in twins: A metaanalysis. Laterality, 4(3), 265-286.

Siebner, H. R., Limmer, C., Peinemann, A., Drzezga, A., Bloem, B. R., Schwaiger, M., \& Conrad, B. (2002). Long term consequences of switching handedness: A positron emission tomography study on handwriting in 'converted' left handers. The Journal of Neuroscience, 22(7), 2816-2825.

Silva, D. A., \& Satz, P. (1979). Pathological left-handedness: Evaluation of a model. Brain and Language, 7(1), 8-16.

*Singh, M., \& Bryden, M. P. (1994). The factor structure of handedness in India. International Journal of Neuroscience, 74, 33-43.

*Smith, J. (1987). Left-handedness: Its association with allergic disease. Neuropsychologia, 25(4), 665-674.

Somers, M., Aukes, M. F., Ophoff, R. A., Boks, M. P., Fleer, W., Kahn, R. S., \& Sommer, I. E. (2015). On the relationship between degree of hand-preference and degree of language lateralization. Brain and Language, 144, 10-15.

Somers, M., Ophoff, R. A., Aukes, M. F., Cantor, R. M., Boks, M. P., Dauwan, M., ... Sommer, I. E. (2015). Linkage analysis in a Dutch population isolate shows no major gene for left-handedness or atypical language lateralization. The Journal of Neuroscience, 35(23), 8730-8736.

Sommer, I., Ramsey, N., Kahn, R., Aleman, A., \& Bouma, A. (2001). Handedness, language lateralization and anatomical asymmetry in schizophrenia. The British Journal of Psychiatry, 178, 344-351. 
Sparrow, S., Manning, J. R., Cartier, J., Anblagan, D., Bastin, M. E., Piyasena, C., ... Evans, M. (2016). Epigenomic profiling of preterm infants reveals DNA methylation differences at sites associated with neural function. Translational Psychiatry, 6(1), e716.

*Spiegler, B. J., \& Yeni-Komshian, G. H. (1983). Incidence of left-handed writing in a college population with reference to family patterns of hand preference. Neuropsychologia, 21(6), 651-659.

*Stoyanov, Z., Nikolova, P., \& Pashalieva, I. (2011). Season of birth, Geschwind and Galaburda hypothesis, and handedness. Laterality, 16(5), 607-619.

*Suar, D., Mandal, M. K., Misra, I., \& Suman, S. (2013). Patterns of hand preference and unintentional injuries among Indian attempted hand switchers and hand nonswitchers. Laterality, 18(6), 652-670.

Suzuki, K., \& Ando, J. (2014). Genetic and environmental structure of individual differences in hand, foot, and ear preferences: A twin study. Laterality, 19(1), 113-128.

Tan, L. E. (1983). Handedness in two generations. Perceptual and Motor Skills, 56, 867-874.

*Tan, Ü. (1986). Symmetric distribution in latencies of cortical somatosensory potentials evoked by right and left posterior tibial nerve stimulation in right-, left-, and mixedhanded men and women. Perceptual and Motor Skills, 62(1), 39-47.

*Tan, Ü. (1988). The relationship between nonverbal intelligence, familial sinistrality and Geschwind scores in right-handed female subjects. International Journal of Neuroscience, 43, 177-182.

*Tapley, S. M., \& Bryden, M. P. (1985). A group test for the assessment of performance between the hands. Neuropsychologia, 23(2), 215-221. 
Teng, E. L., \& Lee, P. H. (1976). Handedness in a Chinese population: Biological, social and pathological factors. Science, 193, 891-902.

*Teng, E. L., Lee, P. H., Yang, K. S., \& Chang, P. C. (1979). Lateral Preferences for hand, foot and eye and their lack of association with scholastic achievement in 4143 Chinese. Neuropsychologia, 17, 41-48.

*Thompson, A. L., \& Marsh, J. F., Jr. (1976). Probability sampling of manual asymmetry. Neuropsychologia, 14(2), 217-223.

Todor, J. L., \& Doane, T. (1977). Handedness classification: preference versus proficiency. Perceptual and Motor Skills, 45, 1041-1042.

*Tonetti, L., Adan, A., Caci, H., Fabbri, M., \& Natale, V. (2012). Season of birth and handedness in young adults. Laterality, 17(5), 597-601.

*Tran, U. S., Stieger, S., \& Voracek, M. (2014). Latent variable analysis indicates that seasonal anisotropy accounts for the higher prevalence of left-handedness in men. Cortex, 57, 188-197.

Triggs, W. J., Calvanio, R., Levine, M., Heaton, R. K., \& Heilman, K. M. (2000). Predicting hand preference with performance on motor tasks. Cortex, 36(5), 679-689.

*Tsuang, H. C., Chen, W. J., Kuo, S. Y., \& Hsiao, P. C. (2016). Handedness and schizotypy: The potential effect of changing the writing-hand. Psychiatry Research, 242, 198203.

Uomini, N. T., \& Ruck, L. (2018). Manual laterality and cognition through evolution: An archeological perspective. Progress in Brain Research, 238, 295-323.

Vallortigara, G., \& Rogers, L. J. (2005). Survival with an asymmetrical brain: advantages and disadvantages of cerebral lateralization. Behavioral and Brain Sciences, 28(4), 575633. 
van Dyck, L. I., Pittman, B. P., \& Blumberg, H. P. (2012). Non-right-handedness in adolescents and adults with bipolar disorder. Bipolar Disorders, 14(5), 571-572.

Viechtbauer, W. (2010). Conducting meta-analyses in R with the metafor package. Journal of Statistical Software, 36, 1-48.

Vuoksimaa, E., Koskenvuo, M., Rose, R. J., \& Kaprio, J. (2009). Origins of handedness: A nationwide study of 30161 adults. Neuropsychologia, 47(5), 1294-1301.

*Walker, L., \& Henneberg, M. (2007). Writing with the non-dominant hand: Crosshandedness trainability in adult individuals. Laterality, 12(2), 121-130.

Wiberg, A., Douaud, G., Ng, M., Al Omran, Y., Alfaro-Almagro, F., Marchini, J., ... Furniss, D. (2019). Human handedness: genetics, microtubules, neuropsychiatric diseases and brain language areas. Brain, 142, 2938-2947.

Willems, R. M., Van der Haegen, L., Fisher, S. E., \& Francks, C. (2014). On the other hand: including left-handers in cognitive neuroscience and neurogenetics. Nature Reviews Neuroscience, 15(3), 193.

*Wolf, P. A., D'Agostino, R. B., \& Cobb, J. (1991). Left-handedness and life expectancy. New England Journal of Medicine, 325, 1042-1042.

*Wood, C. J., \& Aggleton, J. P. (1989). Handedness and 'fast ball' sports: Do left-handers have an innate advantage? British Journal of Psychology, 80, 227-240.

*Wood, C. J., \& Aggleton, J. P. (1991). Occupation and handedness: an examination of architects and mail survey cases. Canadian Journal of Psychology, 45, 395-404.

*Xu, Y., \& Zheng, Y. (2017). Fraternal birth order, handedness, and sexual orientation in a Chinese Population. Journal of Sex Research, 54(1), 10-18.

*You, J. S., Kim, H., Park, J. S., Baek, K. M., Jang, M. S., Lee, H. S., ... Kim, S. W. (2015). Relative effectiveness of dominant versus non-dominant hand position for rescuer's 
side of approach during chest compressions between right-handed and left-handed novice rescuers. Emergency Medicine Journal, 32(3), 184-188.

*Yule, M. A., Brotto, L. A., \& Gorzalka, B. B. (2014). Biological markers of asexuality: Handedness, birth order, and finger length ratios in self-identified asexual men and women. Archives of Sexual Behavior, 43(2), 299-310.

Zheng, M., Ho, C. S., Chan, J. K., McBride, C., Choy, K. W., \& Paracchini, S. (2019). Prevalence and Heritability of Handedness in a Chinese Twin and Singleton Sample. PsyArXiv. doi: https://doi.org/10.31234/osf.io/anq79 [preprint].

*Zhu, J. L., Obel, C., Basso, O., Bech, B. H., Henriksen, T. B., \& Olsen, J. (2009). Handedness and time to pregnancy. Epidemiology, 20(1), 52-55.

Zverev, Y. P. (2006). Cultural and environmental pressure against left-hand preference in urban and semi-urban Malawi. Brain and Cognition, 60(3), 295-303. 
HUMAN HANDEDNESS: A META-ANALYSIS

Table 1.

Details of Studies Included in the Meta-Analyses

\begin{tabular}{|c|c|c|c|c|c|c|c|c|c|c|c|c|c|c|c|}
\hline \multirow[t]{2}{*}{ Study } & \multirow[t]{2}{*}{$\begin{array}{c}\mathbf{N} \\
\text { (Males) }\end{array}$} & \multirow[t]{2}{*}{$\begin{array}{c}\mathrm{N} \\
\text { (Females) }\end{array}$} & \multirow[t]{2}{*}{$\begin{array}{c}\mathrm{N} \\
\text { (total) }\end{array}$} & \multirow{2}{*}{$\begin{array}{c}\text { Geograp } \\
\text { hical } \\
\text { location }\end{array}$} & \multicolumn{2}{|c|}{$\begin{array}{c}\begin{array}{c}\% \text { left- } \\
\text { handedness } \\
\text { (total) }\end{array} \\
\end{array}$} & \multicolumn{2}{|c|}{$\begin{array}{c}\% \text { left- } \\
\text { handedness } \\
\text { stringent }\end{array}$} & \multicolumn{2}{|c|}{$\begin{array}{c}\text { \% left- } \\
\text { handedness } \\
\text { extreme }\end{array}$} & \multicolumn{2}{|c|}{$\begin{array}{c}\% \text { mixed- } \\
\text { handedness }\end{array}$} & $\begin{array}{l}\% \text { non-right- } \\
\text { handedness }\end{array}$ & \multirow{2}{*}{$\begin{array}{l}\text { Measure of } \\
\text { handedness }\end{array}$} & \multirow[t]{2}{*}{ Notes } \\
\hline & & & & & M & F & $\mathbf{M}$ & F & $\mathbf{M}$ & $\mathbf{F}$ & $\mathbf{M}$ & $\mathbf{F}$ & $\begin{array}{ll}\mathbf{M} & \mathbf{F}\end{array}$ & & \\
\hline $\begin{array}{l}\text { Aggleton, } \\
\text { Kentridge, \& } \\
\text { Good (1994) }\end{array}$ & 1,006 & 532 & 1,538 & UK & 12.52 & 12.59 & 12.52 & 12.59 & & & & & & Writing hand & $\begin{array}{l}\text { Data also reported } \\
\text { from } 10 \text {-item } \\
\text { Edinburgh } \\
\text { Handedness Inventory } \\
\text { (EHI) }\end{array}$ \\
\hline \multirow{2}{*}{$\begin{array}{l}\text { Aggleton \& Wood } \\
\text { (1990) }\end{array}$} & 131 & 213 & 344 & \multirow{2}{*}{ USA/UK } & 9.92 & 6.57 & 9.92 & 6.57 & & & & & & \multirow{2}{*}{$\begin{array}{l}\text { Hand used for } \\
\text { bowling } \\
\text { (official } \\
\text { records/ self- } \\
\text { report of } \\
\text { bowling hand) }\end{array}$} & \\
\hline & 199 & 164 & 363 & & 8.04 & 14.63 & & & 8.04 & 14.63 & 3.52 & 3.05 & & & \\
\hline $\begin{array}{l}\text { Anakwe, Huntley, } \\
\& \text { McEachan } \\
(2007)\end{array}$ & 172 & 78 & 250 & UK & 8.72 & 14.10 & 8.72 & 14.10 & & & & & & $\begin{array}{l}\text { Self- } \\
\text { classification (if } \\
\text { no preference } \\
\text { for the } \\
\text { dominant hand } \\
\text { was claimed, } \\
\text { the writing hand } \\
\text { was taken into } \\
\text { account) }\end{array}$ & \\
\hline Annett (1973) & $\begin{array}{l}2,151 \\
3,644 \\
\end{array}$ & $\begin{array}{l}1,493 \\
3,644 \\
\end{array}$ & $\begin{array}{l}3,644 \\
7,288 \\
\end{array}$ & UK & $\begin{array}{l}11.76 \\
4.39 \\
\end{array}$ & $\begin{array}{l}11.45 \\
3.70 \\
\end{array}$ & $\begin{array}{l}11.76 \\
4.39 \\
\end{array}$ & $\begin{array}{l}11.45 \\
3.70 \\
\end{array}$ & & & & & & Writing hand & \\
\hline \multirow{3}{*}{ Annett (1979) } & 397 & 407 & 804 & \multirow{3}{*}{ UK } & 6.55 & 8.60 & 6.55 & 8.60 & & & & & & Writing hand & \multirow{3}{*}{$\begin{array}{l}\text { Information on the } \\
\text { handedness of siblings } \\
\text { reported as well, but } \\
\text { age was unknown, } \\
\text { possibly under } 16 \text { yr. }\end{array}$} \\
\hline & 322 & 368 & 690 & & 12.73 & 4.62 & 12.73 & 4.62 & & & & & & $\begin{array}{c}\text { report by } \\
\text { spouses on } \\
\text { writing hand } \\
\end{array}$ & \\
\hline & 756 & 784 & 1540 & & 6.35 & 5.99 & 6.35 & 5.99 & & & & & & $\begin{array}{l}\text { filial report on } \\
\text { writing hand }\end{array}$ & \\
\hline \multirow[b]{3}{*}{ Annett (1985) } & 321 & 321 & 642 & - & 6.55 & 8.60 & 6.55 & 8.60 & & & & & & Not reported & \multirow{3}{*}{$\begin{array}{l}\text { Data reported in } \\
\text { Annett (2002) \& } \\
\text { Raymond et al. (1996) }\end{array}$} \\
\hline & 357 & 390 & 747 & - & 32.75 & 40.05 & 32.75 & 40.05 & & & & & & Not reported & \\
\hline & 128 & 96 & 224 & - & 12.73 & 4.62 & 12.73 & 4.62 & & & & & & hand holding & \\
\hline
\end{tabular}


HUMAN HANDEDNESS: A META-ANALYSIS

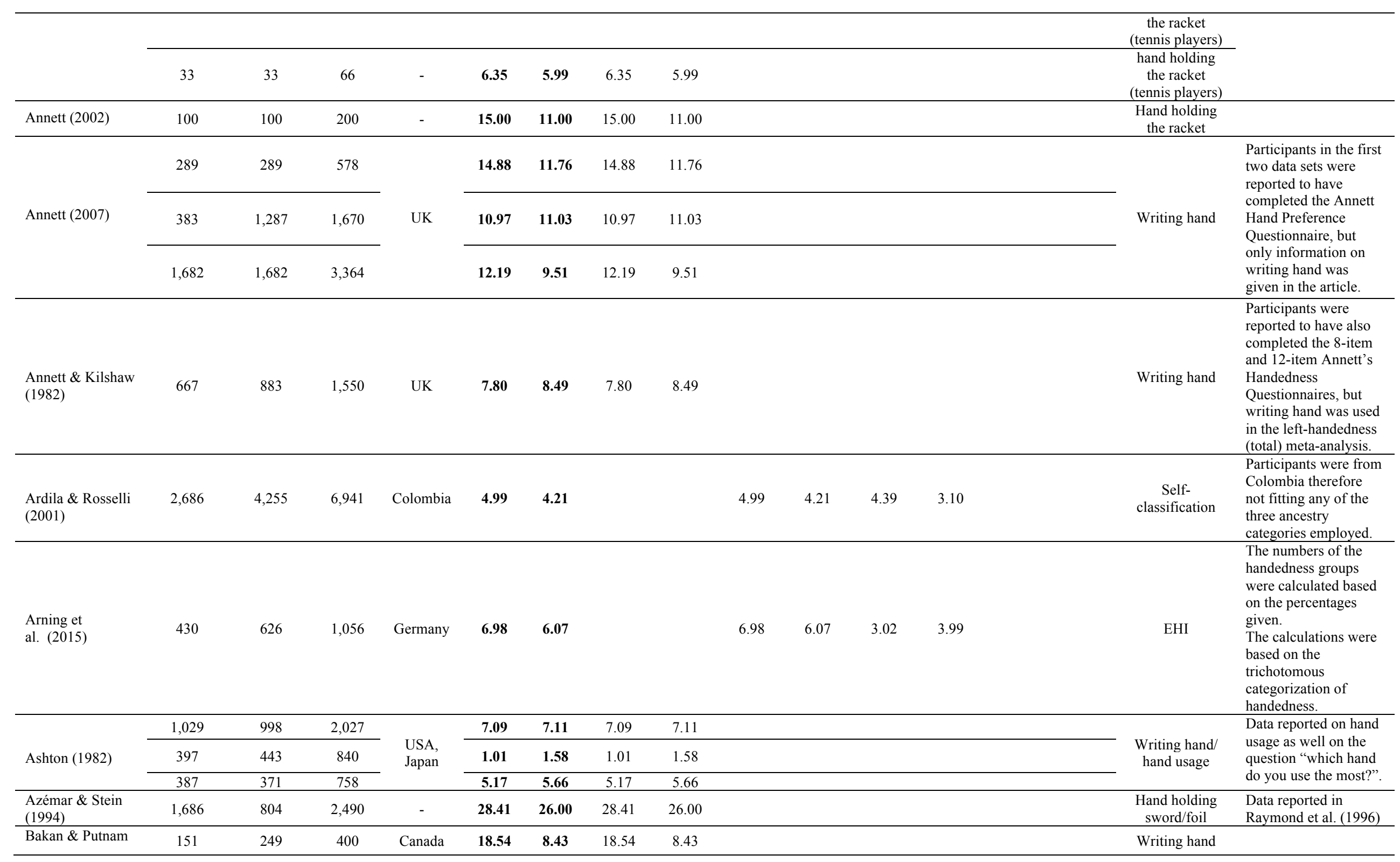


HUMAN HANDEDNESS: A META-ANALYSIS

\begin{tabular}{|c|c|c|c|c|c|c|c|c|c|c|c|c|c|c|c|c|}
\hline (1974) & & & & & & & & & & & & & & & & \\
\hline $\begin{array}{l}\text { Barut, Ozer, } \\
\text { Sevinc, Gumus \& } \\
\text { Yunten (2007) }\end{array}$ & 343 & 290 & 633 & Turkey & 18.95 & 11.72 & & & 18.95 & 11.72 & 7.29 & 2.76 & & & $\begin{array}{c}\text { 10-item } \\
\text { EHI }\end{array}$ & \\
\hline $\begin{array}{l}\text { Beckman \& } \\
\text { Elston (1962) }\end{array}$ & 492 & 489 & 981 & Sweden & 5.28 & 5.73 & 5.28 & 5.73 & & & & & & & Not reported & \\
\hline $\begin{array}{l}\text { Betancur, Velez, } \\
\text { Cabanieu, } \\
\text { LeMoal, \& Neveu } \\
\text { (1990) }\end{array}$ & 93 & 112 & 205 & France & 9.68 & 9.82 & & & 9.68 & 9.82 & 19.35 & 16.07 & & & $\begin{array}{l}\text { Modified } \\
\text { version of 10- } \\
\text { item EHI }\end{array}$ & $\begin{array}{l}\text { The participants were } \\
\text { controls to allergic } \\
\text { patients. }\end{array}$ \\
\hline Birkett (1981) & 54 & 71 & 125 & UK & 38.89 & 43.66 & 38.89 & 43.66 & & & & & & & 10-item EHI & \\
\hline $\begin{array}{l}\text { Briggs \& Nebes } \\
\text { (1975) }\end{array}$ & 831 & 768 & 1,599 & USA & 8.90 & 9.38 & & & 8.90 & 9.38 & 5.66 & 4.82 & & & $\begin{array}{l}\text { 12-item Briggs- } \\
\text { Nebes } \\
\text { modification of } \\
\text { Annett's } \\
\text { questionnaire }\end{array}$ & \\
\hline $\begin{array}{l}\text { Brito, Brito, } \\
\text { Paumgartten, \& } \\
\text { Lins (1989) }\end{array}$ & 471 & 488 & 959 & Brazil & 3.40 & 2.66 & 3.40 & 2.66 & & & & & & & 10-item EHI & $\begin{array}{l}\text { Participants were from } \\
\text { Brazil therefore not } \\
\text { fitting any of the three } \\
\text { ancestry categories } \\
\text { employed. }\end{array}$ \\
\hline Bryden (1977) & 620 & 486 & 1,106 & Canada & 12.10 & 9.05 & 12.10 & 9.05 & & & & & & & Writing hand & $\begin{array}{l}\text { 1. Data also reported } \\
\text { for self-classification } \\
\text { 2. The participants } \\
\text { were also administered } \\
\text { the Crovitz-Zener and } \\
\text { Oldfield's } \\
\text { questionnaires, but } \\
\text { only mean scores for } \\
\text { each question for M-F } \\
\text { were given. }\end{array}$ \\
\hline Bryden (1989) & 334 & 460 & 794 & Canada & 11.08 & 7.39 & 11.08 & 7.39 & & & & & & & $\begin{array}{c}8 \text {-items from } \\
\text { EHI }\end{array}$ & \\
\hline $\begin{array}{l}\text { Bryden \& Roy } \\
(2005)\end{array}$ & 47 & 106 & 153 & Canada & 17.02 & 8.49 & 17.02 & 8.49 & & & & & & & Writing hand & \\
\hline $\begin{array}{l}\text { Buchtel \& } \\
\text { Rueckert (1984) }\end{array}$ & 365 & 375 & 740 & USA & 13.70 & 13.07 & 13.70 & 13.07 & & & & & & & Writing hand & \\
\hline $\begin{array}{l}\text { Cannon et al. } \\
(1995)\end{array}$ & 21 & 22 & 43 & Ireland & 4.76 & 9.09 & & & 4.76 & 9.09 & 19.05 & 4.55 & & & 10-item EHI & $\begin{array}{l}\text { The participants were } \\
\text { controls to patients } \\
\text { with schizophrenia. }\end{array}$ \\
\hline $\begin{array}{l}\text { Carriere \& } \\
\text { Raymond (2000) }\end{array}$ & 133 & 113 & 246 & $\begin{array}{l}\text { Came- } \\
\text { roon }\end{array}$ & 9.02 & 7.08 & 9.02 & 7.08 & & & & & & & $\begin{array}{c}\text { Observation of } \\
\text { which hand was } \\
\text { used to hold the } \\
\text { machete. }\end{array}$ & $\begin{array}{l}\text { Children were also } \\
\text { included in the sample, } \\
\text { but the age variable } \\
\text { was not significant. }\end{array}$ \\
\hline $\begin{array}{l}\text { Casey \& Brabeck } \\
(1989)\end{array}$ & 119 & 314 & 433 & USA & 26.89 & 25.48 & & & & & & & 26.89 & 25.48 & 10-item EHI & \\
\hline
\end{tabular}


HUMAN HANDEDNESS: A META-ANALYSIS

\begin{tabular}{|c|c|c|c|c|c|c|c|c|c|c|c|c|c|c|}
\hline $\begin{array}{l}\text { Chamberlain } \\
(1928)\end{array}$ & 2,177 & 2,177 & 4,354 & USA & 4.18 & 2.94 & 4.18 & 2.94 & & & & & $\begin{array}{l}\text { Writing hand } \\
\text { (by filial report) }\end{array}$ & $\begin{array}{l}\text { The reporters' data } \\
\text { were not included, as } \\
\text { they were all male as } \\
\text { well as the data on } \\
\text { their siblings' } \\
\text { handedness because } \\
\text { their age was } \\
\text { unknown. }\end{array}$ \\
\hline $\begin{array}{l}\text { Chapman \& } \\
\text { Walsh (1973) }\end{array}$ & 633 & 290 & 923 & Australia & 12.16 & 13.10 & & & 12.16 & 13.10 & 1.11 & 1.03 & Throwing a ball & \\
\hline $\begin{array}{l}\text { Chapman \& } \\
\text { Chapman (1987) }\end{array}$ & 2,786 & 3,039 & 5,825 & USA & 6.89 & 6.19 & & & 6.89 & 6.19 & 12.49 & 9.90 & $\begin{array}{c}13 \text {-item } \\
\text { questionnaire }\end{array}$ & \\
\hline $\begin{array}{l}\text { Chen, Sachdev, } \\
\text { Wen, \& Anstey } \\
\text { (2007) }\end{array}$ & 184 & 227 & 411 & Australia & 10.87 & 10.57 & 10.87 & 10.57 & & & & & EHI & \\
\hline Chisnall (2010) & 185 & 117 & 302 & Canada & 14.05 & 15.38 & & & 14.05 & 15.38 & 1.62 & 0.85 & Writing hand & $\begin{array}{l}\text { Participants from the } \\
\text { age groups } 0-10 \text { and } \\
10-20 \text { were excluded } \\
\text { due to the age } \\
\text { criterion. Only } 302 \\
\text { participants remained. }\end{array}$ \\
\hline $\begin{array}{l}\text { Çiçek, Arabacı, \& } \\
\text { Çanakçı (2010) }\end{array}$ & 720 & 790 & 1,510 & Turkey & 9.17 & 7.85 & 9.17 & 7.85 & & & & & EHI & \\
\hline Coren (1989) & 810 & 1,086 & 1,896 & Canada & 10.37 & 8.84 & 10.37 & 8.84 & & & & & $\begin{array}{l}\text { The } 4 \text { items for } \\
\text { handedness } \\
\text { from the Lateral } \\
\text { Preference } \\
\text { Inventory by } \\
\text { Coren }\end{array}$ & \\
\hline Coren (1993) & 1,375 & 1,932 & 3,307 & Canada & 11.78 & 9.21 & 11.78 & 9.21 & & & & & $\begin{array}{l}\text { The } 4 \text { items for } \\
\text { handedness } \\
\text { from the Lateral } \\
\text { Preference } \\
\text { Inventory by } \\
\text { Coren }\end{array}$ & \\
\hline Coren (1995) & 1,298 & 1,298 & 2,596 & Canada & 9.78 & 8.32 & 9.78 & 8.32 & & & & & $\begin{array}{l}\text { The } 4 \text { items for } \\
\text { handedness } \\
\text { from the Lateral } \\
\text { Preference } \\
\text { Inventory by } \\
\text { Coren } \\
\end{array}$ & $\begin{array}{l}\text { The data on the } \\
\text { handedness of the } \\
\text { reporters and their } \\
\text { siblings were not } \\
\text { broken down by sex. }\end{array}$ \\
\hline \multirow[t]{2}{*}{$\begin{array}{l}\text { Coren \& Porac } \\
\text { (1979) }\end{array}$} & 802 & 956 & 1,758 & Canada & 11.35 & 10.46 & 11.35 & 10.46 & & & & & Writing hand & \\
\hline & 1,284 & 1,477 & 2,761 & Canada & 11.45 & 10.49 & 11.45 & 10.49 & & & & & $\begin{array}{l}\text { The } 4 \text {-items for } \\
\text { handedness } \\
\text { from the Lateral }\end{array}$ & \\
\hline
\end{tabular}


HUMAN HANDEDNESS: A META-ANALYSIS

\begin{tabular}{|c|c|c|c|c|c|c|c|c|c|c|c|c|c|c|}
\hline $\begin{array}{l}\text { Coren \& Porac } \\
\text { (1980) }\end{array}$ & 684 & 726 & 1,410 & & 12.43 & 9.92 & 12.43 & 9.92 & & & & & $\begin{array}{l}\text { Preference } \\
\text { Inventory by } \\
\text { Coren }\end{array}$ & \\
\hline $\begin{array}{l}\text { Coren, Searleman, } \\
\& \text { Porac (1986) }\end{array}$ & 467 & 713 & 1,180 & Canada & 12.85 & 8.42 & 12.85 & 8.42 & & & & & $\begin{array}{l}\text { The } 4 \text { items for } \\
\text { handedness } \\
\text { from the Lateral } \\
\text { Preference } \\
\text { Inventory by } \\
\text { Coren }\end{array}$ & \\
\hline $\begin{array}{l}\text { Cornell \& } \\
\text { McManus (1992) }\end{array}$ & 142 & 124 & 266 & UK & 7.75 & 13.71 & 7.75 & 13.71 & & & & & Writing hand & \\
\hline \multirow{2}{*}{$\begin{array}{l}\text { Cosenza \& } \\
\text { Mingoti (1993) }\end{array}$} & 1,040 & 921 & 1,961 & \multirow{2}{*}{ Brazil } & 10.96 & 7.82 & 10.96 & 7.82 & & & & & 10 -item $\mathrm{EHH}$ & \multirow{3}{*}{$\begin{array}{l}\text { Participants were from } \\
\text { Brazil therefore not } \\
\text { fitting any of the three } \\
\text { ancestry categories } \\
\text { employed. }\end{array}$} \\
\hline & 6,226 & 8,403 & 14,629 & & 8.88 & 7.14 & 8.88 & 7.14 & & & & & 10-1еЕ БП1 & \\
\hline $\begin{array}{l}\text { Cosenza \& } \\
\text { Mingoti (1995) }\end{array}$ & 6,654 & 8,735 & 15,389 & Brazil & 8.79 & 7.17 & 8.79 & 7.17 & & & & & 10-item EHI & \\
\hline Cuff (1931) & 17 & 92 & 109 & USA & 5.88 & 7.61 & 5.88 & 7.61 & & & & & $\begin{array}{c}\text { 8-item } \\
\text { questionnaire }\end{array}$ & $\begin{array}{l}\text { The paper reported } \\
\text { data on children as } \\
\text { well, not used here. }\end{array}$ \\
\hline $\begin{array}{l}\text { Curt, De Agostini, } \\
\text { Maccario, \& } \\
\text { Dellatolas (1995) }\end{array}$ & 777 & 832 & 1,609 & France & 8.75 & 8.77 & 8.75 & 8.77 & & & & & $\begin{array}{l}\text { 12-item hand } \\
\text { preference } \\
\text { questionnaire }\end{array}$ & \\
\hline $\begin{array}{l}\text { Dane \& } \\
\text { Erzurumluoğlu } \\
(2003)\end{array}$ & 160 & 166 & 326 & Turkey & 19.38 & 15.06 & 19.38 & 15.06 & & & & & 10-item EHI & \\
\hline \multirow[t]{2}{*}{ Dane (2019) } & 52 & 55 & 107 & Nigeria & 19.23 & 5.45 & 19.23 & 5.45 & & & & & \multirow{2}{*}{ EHI } & \multirow{2}{*}{$\begin{array}{l}\text { Calculations based on } \\
\text { unpublished raw data } \\
\text { kindly provided by the } \\
\text { author. }\end{array}$} \\
\hline & 125 & 75 & 200 & Nigeria & 8.00 & 8.00 & 8.00 & 8.00 & & & & & & \\
\hline Dane et al. (2009) & 60 & 58 & 118 & Turkey & 6.67 & 3.45 & & & 6.67 & 3.45 & 21.67 & 17.24 & EHI & \\
\hline \multirow{4}{*}{$\begin{array}{l}\text { Dargent-Paré, De } \\
\text { Agostini, } \\
\text { Meshbah, Mounir, } \\
\text { Dellatolas (1992) }\end{array}$} & 312 & 340 & 652 & Algeria & 5.45 & 5.88 & 5.45 & 5.88 & & & & & \multirow{4}{*}{$\begin{array}{l}\text { 12-item } \\
\text { questionnaire }\end{array}$} & \\
\hline & 374 & 311 & 685 & Greece & 6.68 & 5.79 & 6.68 & 5.79 & & & & & & \\
\hline & 502 & 199 & 701 & Italy & 8.37 & 4.52 & 8.37 & 4.52 & & & & & & \\
\hline & $\begin{array}{c}375 \\
1024\end{array}$ & $\begin{array}{c}350 \\
1277\end{array}$ & 725 & Spain & $\begin{array}{l}8.00 \\
850\end{array}$ & $\begin{array}{l}4.86 \\
0.48\end{array}$ & $\begin{array}{l}8.00 \\
850\end{array}$ & $\begin{array}{l}4.86 \\
0.48\end{array}$ & & & & & & \\
\hline \multirow{3}{*}{$\begin{array}{l}\text { De Agostini, } \\
\text { Khamis, Ahui, \& } \\
\text { Dellatolas (1997) }\end{array}$} & 382 & 382 & 764 & \multirow{3}{*}{$\begin{array}{l}\text { Ivory } \\
\text { Coast }\end{array}$} & 9.16 & 4.97 & 9.16 & 4.97 & & & & & filial report & \\
\hline & 397 & 358 & 755 & & 5.04 & 5.03 & 5.04 & 5.03 & & & & & $\begin{array}{c}10 \text {-item } \\
\text { questionnaire }\end{array}$ & \\
\hline & 734 & 736 & 1,470 & & 6.40 & 5.03 & 6.40 & 5.03 & & & & & filial report & \\
\hline $\begin{array}{l}\text { De Kovel, } \\
\text { Carrión-Castillo, } \\
\text { \& Francks (2019) }\end{array}$ & 228,554 & 272,893 & $\begin{array}{c}501,44 \\
7\end{array}$ & $\begin{array}{l}41 \% \text { UK } \\
59 \% \text { other }\end{array}$ & 10.41 & 8.45 & & & 10.41 & 8.45 & 2.12 & 1.40 & $\begin{array}{c}\text { Self- } \\
\text { classification }\end{array}$ & $\begin{array}{l}\text { Official records from } \\
\text { UK Biobank dataset. }\end{array}$ \\
\hline \multirow{2}{*}{$\begin{array}{l}\text { De la Fuente, } \\
\text { Casasanto, }\end{array}$} & 43 & 51 & 94 & Morocco & 0.00 & 0.00 & 0.00 & 0.00 & & & & & FHI & \multirow{2}{*}{$\begin{array}{l}\text { Despite collecting } \\
\text { large samples, in } 3 \text { out } \\
\text { of } 4 \text { datasets, no LH }\end{array}$} \\
\hline & 36 & 35 & 71 & Spain & 0.00 & 0.00 & 0.00 & 0.00 & & & & & LIII & \\
\hline
\end{tabular}


HUMAN HANDEDNESS: A META-ANALYSIS

\begin{tabular}{|c|c|c|c|c|c|c|c|c|c|c|c|c|c|c|}
\hline $\begin{array}{l}\text { Román, \& } \\
\text { Santiago (2015) }\end{array}$ & 25 & 15 & 40 & Morocco & 0.00 & 0.00 & 0.00 & 0.00 & & & & & $\begin{array}{c}\text { 4-item } \\
\text { handedness } \\
\text { performance } \\
\text { measure }\end{array}$ & were detected. \\
\hline $\begin{array}{l}\text { DeLisi et al. } \\
(2002)\end{array}$ & 135 & 153 & 288 & $\begin{array}{l}\text { USA, UK, } \\
\text { Italy }\end{array}$ & 9.63 & 3.27 & & & 9.63 & 3.27 & 9.63 & 7.84 & $\begin{array}{c}23 \text {-item } \\
\text { Annett's } \\
\text { questionnaire }\end{array}$ & \\
\hline $\begin{array}{l}\text { Demura et al.a } \\
(2006)\end{array}$ & 2,429 & 1,128 & 3,557 & Japan & 6.55 & 3.19 & & & 6.55 & 3.19 & 1.81 & 2.84 & $\begin{array}{l}\text { 10-item EHI } \\
\text { Handedness } \\
\text { Inventory }\end{array}$ & $\begin{array}{l}\text { Data also reported on } \\
\text { each participant's } \\
\text { dominant hand for } \\
\text { various sports. }\end{array}$ \\
\hline $\begin{array}{l}\text { Dinsdale, } \\
\text { Reddon, \& Hurd } \\
\text { (2011) }\end{array}$ & 188 & 207 & 395 & Canada & 11.17 & 9.18 & & & 11.17 & 9.18 & 0.00 & 0.48 & $\begin{array}{l}\text { EHI, writing } \\
\text { hand }\end{array}$ & $\begin{array}{l}\text { The writing hand was } \\
\text { taken into account for } \\
\text { the meta-analysis. }\end{array}$ \\
\hline Dirnberger (2012) & 401 & 614 & 1,015 & Austria & 8.23 & 6.51 & 8.23 & 6.51 & & & & & EHI & $\begin{array}{l}2 \mathrm{MH} \text { males excluded } \\
\text { because "For two male } \\
\text { participants with } \\
\mathrm{L}=0 \text { the direction of } \\
\text { handedness could not } \\
\text { be calculated, and they } \\
\text { were } \\
\text { therefore excluded } \\
\text { from further analysis". }\end{array}$ \\
\hline Downey (1927) & 421 & 300 & 721 & USA & 6.18 & 3.33 & 6.18 & 3.33 & & & & & $\begin{array}{c}5 \text {-item } \\
\text { questionnaire }\end{array}$ & $\begin{array}{l}\text { Data also reported on } \\
\text { a group of adult \& } \\
\text { juvenile delinquents, } \\
\text { inmates of institutions } \\
\text { for the feebleminded } \\
\text { and insane and boys } \\
\text { and girls in special } \\
\text { classes for subnormal } \\
\text { children, but not used } \\
\text { here. }\end{array}$ \\
\hline $\begin{array}{l}\text { Dragovic, } \\
\text { Milenkovic, \& } \\
\text { Hammond (2008) }\end{array}$ & 357 & 430 & 787 & Australia & 12.89 & 9.07 & 12.89 & 9.07 & & & & & $\begin{array}{l}\text { EHI, writing } \\
\text { hand }\end{array}$ & $\begin{array}{l}\text { The writing hand was } \\
\text { taken into account for } \\
\text { the meta-analysis. }\end{array}$ \\
\hline Dronamraju & 213 & 218 & 431 & India & 15.49 & 7.80 & 15.49 & 7.80 & & & & & Hand used to & \\
\hline (1975) & 43 & 43 & 86 & India & 6.98 & 4.65 & 6.98 & 4.65 & & & & & hold a brush & \\
\hline $\begin{array}{l}\text { Elalmis \& Tan } \\
(2005)\end{array}$ & 11,492 & 10,969 & 22,461 & Turkey & 7.96 & 7.19 & & & 7.96 & 7.19 & 2.64 & 2.35 & $\begin{array}{c}\text { Self- } \\
\text { classification }\end{array}$ & \\
\hline $\begin{array}{l}\text { Elalmis \& Tan } \\
(2008)\end{array}$ & 91 & 106 & 197 & Turkey & 16.48 & 6.60 & 16.48 & 6.60 & & & & & Writing hand & \\
\hline $\begin{array}{l}\text { Elias, Saucier, \& } \\
\text { Guylee (2001) }\end{array}$ & 117 & 424 & 541 & Canada & 14.53 & 8.96 & 14.53 & 8.96 & & & & & $\begin{array}{c}\text { Self- } \\
\text { classification }\end{array}$ & \\
\hline $\begin{array}{l}\text { Ellis, Ellis, \& } \\
\text { Marshall (1988) } \\
\end{array}$ & 3,070 & 3,507 & 6,577 & USA & 7.79 & 6.87 & 7.79 & 6.87 & & & & & 10-item EHI & \\
\hline
\end{tabular}


HUMAN HANDEDNESS: A META-ANALYSIS

\begin{tabular}{|c|c|c|c|c|c|c|c|c|c|c|c|c|c|c|c|c|}
\hline $\begin{array}{l}\text { Elneel, Carter, } \\
\text { Tang, \& Cuschieri } \\
(2008)\end{array}$ & 32 & 20 & 52 & Italy & 37.50 & 0.00 & & & 37.50 & 0.00 & 0.00 & 0.00 & & & $\begin{array}{l}\text { Handedness } \\
\text { questionnaire } \\
\text { (direct } \\
\text { questions) } \\
\end{array}$ & \\
\hline $\begin{array}{l}\text { Espírito-Santo et } \\
\text { al. }(2017)\end{array}$ & 157 & 185 & 342 & Portugal & 0.64 & 0.54 & & & 0.64 & 0.54 & 43.31 & 37.84 & & & EHI & \\
\hline $\begin{array}{l}\text { Fagard, } \\
\text { Chapelain, \& } \\
\text { Bonnet (2015) }\end{array}$ & 261 & 443 & 704 & $\begin{array}{l}\text { France, } \\
\text { England }\end{array}$ & 11.11 & 10.61 & & & 11.11 & 10.61 & 4.60 & 2.26 & & & $\begin{array}{c}\text { 15-item } \\
\text { handedness } \\
\text { questionnaire }\end{array}$ & $\begin{array}{l}\text { Calculations based on } \\
\text { raw data kindly } \\
\text { provided by the } \\
\text { authors. }\end{array}$ \\
\hline \multirow{2}{*}{$\begin{array}{l}\text { Faurie et al. } \\
(2008)\end{array}$} & 4,720 & 7,175 & 11,895 & France & 10.38 & 9.41 & 10.38 & 9.41 & & & & & & & $\begin{array}{c}\text { Self- } \\
\text { classification }\end{array}$ & \multirow{2}{*}{$\begin{array}{l}\text { The numbers of the } \\
\text { handedness groups } \\
\text { were calculated based } \\
\text { on the percentages } \\
\text { given. }\end{array}$} \\
\hline & 10,437 & 3,517 & 13,954 & France & 10.55 & 9.35 & 10.55 & 9.35 & & & & & & & $\begin{array}{c}\text { 6-item } \\
\text { handedness } \\
\text { questionnaire } \\
\end{array}$ & \\
\hline \multirow{2}{*}{ Fry (1990) } & 211 & 155 & 366 & \multirow[b]{2}{*}{ USA } & 15.64 & 12.90 & 15.64 & 12.90 & & & & & & & $\begin{array}{l}\text { Offspring: 10- } \\
\text { item EHI }\end{array}$ & \multirow{2}{*}{$\begin{array}{l}\text { Data on siblings' } \\
\text { handedness was also } \\
\text { reported, but was } \\
\text { excluded because age } \\
\text { was not reported. }\end{array}$} \\
\hline & 359 & 362 & 721 & & 11.70 & 11.88 & 11.70 & 11.88 & & & & & & & $\begin{array}{c}\text { Parents: filial } \\
\text { report of writing } \\
\text { hand }\end{array}$ & \\
\hline $\begin{array}{l}\text { Genetta-Wadley } \\
\text { \& Swirsky- } \\
\text { Sacchetti (1990) }\end{array}$ & 30 & 30 & 60 & USA & 10.00 & 3.33 & 10.00 & 3.33 & & & & & & & $\begin{array}{c}12 \text {-item } \\
\text { Annett's } \\
\text { Handedness } \\
\text { Questionnaire } \\
\end{array}$ & \multirow[b]{3}{*}{$\begin{array}{l}\text { The participants were } \\
\text { controls to } \\
\text { homosexual } \\
\text { individuals. }\end{array}$} \\
\hline $\begin{array}{l}\text { Gilbert \& } \\
\text { Wysocki (1992) }\end{array}$ & 513,393 & 664,114 & $\begin{array}{c}1,177 \\
507\end{array}$ & USA & 12.60 & 9.90 & & & & & & & 12.60 & 9.90 & $\begin{array}{l}\text { Writing hand } \\
\text { and throwing } \\
\text { hand }\end{array}$ & \\
\hline $\begin{array}{l}\text { Gladue \& Bailey } \\
\text { (1995) }\end{array}$ & 76 & 73 & 149 & USA & 35.53 & 28.77 & & & & & & & 35.53 & 28.77 & $\begin{array}{c}\text { 10-item Annett } \\
\text { Handedness } \\
\text { Questionnaire } \\
\end{array}$ & \\
\hline \multirow[t]{2}{*}{ Götestam (1990) } & \multirow[t]{2}{*}{110} & \multirow[t]{2}{*}{125} & 60 & \multirow[t]{2}{*}{ Norway } & 9.09 & 9.60 & & & 9.09 & 9.60 & 0.91 & 3.20 & & & Writing hand & \multirow{2}{*}{$\begin{array}{l}\text { Percentages were } \\
\text { given when reporting } \\
\text { results on writing } \\
\text { hand, adding up to } \\
99.1 \% \text { for males and } \\
96.8 \% \text { for females. It } \\
\text { was therefore assumed } \\
\text { that } 0.9 \% \text { of males and } \\
3.2 \% \text { of females used } \\
\text { equally both hands for } \\
\text { writing, making up the } \\
\text { mixed category. }\end{array}$} \\
\hline & & & 175 & & 10.00 & 12.80 & 10.00 & 12.80 & & & & & & & $\begin{array}{c}\text { 4-item } \\
\text { questionnaire }\end{array}$ & \\
\hline $\begin{array}{l}\text { Green \& Young } \\
(2001)\end{array}$ & 144 & 140 & 284 & UK & 23.61 & 27.14 & & & 23.61 & 27.14 & 27.78 & 25.71 & & & $\begin{array}{c}\text { 6-item } \\
\text { questionnaire }\end{array}$ & $\begin{array}{l}\text { The participants were } \\
\text { controls to transsexual } \\
\text { participants. }\end{array}$ \\
\hline
\end{tabular}


HUMAN HANDEDNESS: A META-ANALYSIS

\begin{tabular}{|c|c|c|c|c|c|c|c|c|c|c|c|c|c|c|c|c|}
\hline \multirow{2}{*}{$\begin{array}{l}\text { Grouios, } \\
\text { Tsorbatzoudis, } \\
\text { Alexandris, \& } \\
\text { Barkoukis (2000) }\end{array}$} & 578 & 534 & 1,112 & \multirow{2}{*}{ Greece } & 15.92 & 13.67 & 15.92 & 13.67 & & & & & & \multirow{2}{*}{$\begin{array}{l}\text { 12-item Briggs- } \\
\text { Nebes } \\
\text { modification of } \\
\text { Annett's } \\
\text { questionnaire }\end{array}$} & \multirow[b]{3}{*}{$\begin{array}{l}\text { Data from the Brain } \\
\text { Resource International } \\
\text { Database }\end{array}$} \\
\hline & 623 & 564 & 1,187 & & 10.11 & 7.80 & 10.11 & 7.80 & & & & & & & & \\
\hline $\begin{array}{l}\text { Gunstad, } \\
\text { Spitznagel, } \\
\text { Luyster, Cohen, \& } \\
\text { Paul (2007) } \\
\end{array}$ & 319 & 324 & 643 & $\mathrm{n} / \mathrm{a}$ & 16.61 & 16.36 & & & & & & & 16.61 & 16.36 & EHI & \\
\hline $\begin{array}{l}\text { Gupta, Sanyal, \& } \\
\text { Babbar (2008) }\end{array}$ & 63 & 21 & 84 & $\begin{array}{l}\text { New } \\
\text { Delhi }\end{array}$ & 14.29 & 14.29 & 14.29 & 14.29 & & & & & & & $\begin{array}{c}\text { Self- } \\
\text { classification }\end{array}$ & \\
\hline Gur \& Gur (1977) & 100 & 100 & 200 & USA & 16.00 & 6.00 & 16.00 & 6.00 & & & & & & & $\begin{array}{c}\text { 23-item } \\
\text { Raczkowski et } \\
\text { al.’s } \\
\text { questionnaire } \\
\end{array}$ & \\
\hline $\begin{array}{l}\text { Halpern, } \\
\text { Haviland, \& } \\
\text { Killian (1998) } \\
\end{array}$ & 85,118 & 67,535 & $\begin{array}{c}152,65 \\
3\end{array}$ & USA & 12.60 & 10.40 & 12.60 & 10.40 & & & & & & & Writing hand & \\
\hline $\begin{array}{l}\text { Hannay, Ciaccia, } \\
\text { Kerr, \& Barrett } \\
(1990)\end{array}$ & 578 & 607 & 1,185 & USA & 4.33 & 4.45 & & & 4.33 & 4.45 & 27.51 & 16.14 & & & $\begin{array}{c}10 \text {-item } \\
\text { questionnaire }\end{array}$ & \\
\hline $\begin{array}{l}\text { Hannula, Bloigu, } \\
\text { Majamaa, Sorri, } \\
\text { \& Mäki-Torkko } \\
(2012)\end{array}$ & 383 & 467 & 850 & Finland & 4.18 & 6.42 & 4.18 & 6.42 & & & & & & & $\begin{array}{c}\text { Self- } \\
\text { classification }\end{array}$ & $\begin{array}{l}\text { The numbers of the } \\
\text { handedness groups } \\
\text { were calculated based } \\
\text { on the percentages } \\
\text { given. }\end{array}$ \\
\hline \multirow{2}{*}{$\begin{array}{l}\text { Harburg, } \\
\text { Feldstein, \& } \\
\text { Papsdorf (1978) }\end{array}$} & 364 & 371 & 735 & \multirow{2}{*}{ USA } & 7.69 & 7.03 & 7.69 & 7.03 & & & & & & & \multirow{2}{*}{$\begin{array}{c}\text { Self- } \\
\text { classification }\end{array}$} & \multirow{2}{*}{$\begin{array}{l}\text { Data from survey } \\
\text { interviews from a } \\
\text { larger project } \\
\text { conducted in Detroit } \\
\text { between } 1968-1969 .\end{array}$} \\
\hline & 377 & 384 & 761 & & 8.24 & 5.12 & 8.24 & 5.12 & & & & & & & & \\
\hline \multirow{2}{*}{$\begin{array}{l}\text { Harburg, Roeper, } \\
\text { Ozgoren, \& } \\
\text { Feldstein (1981) }\end{array}$} & 278 & 373 & 651 & \multirow{2}{*}{ USA } & 14.39 & 12.33 & 14.39 & 12.33 & & & & & & & \multirow{2}{*}{ Writing hand } & \\
\hline & 247 & 255 & 502 & & 7.69 & 5.49 & 7.69 & 5.49 & & & & & & & & \\
\hline $\begin{array}{l}\text { Harris \& } \\
\text { Gitterman (1978) }\end{array}$ & 317 & 39 & 356 & USA & 7.26 & 7.69 & 7.26 & 7.69 & & & & & & & $\begin{array}{l}\text { 12-item Briggs } \\
\& \text { Nebes } \\
\text { handedness } \\
\text { questionnaire }\end{array}$ & $\begin{array}{l}\text { Eight additional } \\
\text { female left-handers } \\
\text { were added to provide } \\
\text { more power to the } \\
\text { results of the study, } \\
\text { but were subtracted } \\
\text { from the numbers } \\
\text { reported here. }\end{array}$ \\
\hline Harvey (1988) & 280 & 118 & 398 & UK & 17.14 & 11.86 & 17.14 & 11.86 & & & & & & & 10-item EHI & $\begin{array}{l}\text { Data were also } \\
\text { reported on } 838 \text { th } \\
\text { year pupils as well as } \\
\text { on } 1000 \text { th year } \\
\text { pupils, which were } \\
\text { excluded from the }\end{array}$ \\
\hline
\end{tabular}


HUMAN HANDEDNESS: A META-ANALYSIS

\begin{tabular}{|c|c|c|c|c|c|c|c|c|c|c|c|c|c|c|}
\hline & & & & & & & & & & & & & & meta-analysis. \\
\hline $\begin{array}{l}\text { Hatta \& } \\
\text { Kawakami (1995) }\end{array}$ & 517 & 1,183 & 1,700 & Japan & 6.19 & 4.23 & & & 6.19 & 4.23 & 6.58 & 5.58 & $\begin{array}{c}10 \text {-item } \\
\text { questionnaire }\end{array}$ & \\
\hline $\begin{array}{l}\text { Hatta \& } \\
\text { Nakatsuka (1976) }\end{array}$ & 488 & 711 & 1,199 & Japan & 4.30 & 2.25 & 4.30 & 2.25 & & & & & $\begin{array}{c}10 \text {-item } \\
\text { questionnaire }\end{array}$ & \\
\hline $\begin{array}{l}\text { Heim \& Watts } \\
\text { (1976) }\end{array}$ & $\begin{array}{l}109 \\
340\end{array}$ & $\begin{array}{l}289 \\
152\end{array}$ & $\begin{array}{l}398 \\
492\end{array}$ & UK & $\begin{array}{l}16.51 \\
\mathbf{1 0 . 5 9}\end{array}$ & $\begin{array}{l}9.69 \\
5.92\end{array}$ & $\begin{array}{l}16.51 \\
10.59\end{array}$ & \begin{tabular}{|l|}
9.69 \\
5.92
\end{tabular} & & & & & Writing hand & $\begin{array}{l}\text { Data on younger } \\
\text { participants as well. }\end{array}$ \\
\hline $\begin{array}{l}\text { Heikkilä et al. } \\
\text { (2015) }\end{array}$ & 864 & 927 & 1,791 & Finland & 9.95 & 5.83 & 9.95 & 5.83 & & & & & Writing hand & $\begin{array}{l}\text { The subgroup of the } \\
\text { singletons (controls to } \\
\text { twins) was used for the } \\
\text { meta-analysis. }\end{array}$ \\
\hline $\begin{array}{l}\text { Hicks, Dusek, } \\
\text { Larsen, \& } \\
\text { Pellegrini (1980) }\end{array}$ & 257 & 323 & 580 & USA & 11.28 & 11.15 & 11.28 & 11.15 & & & & & $\begin{array}{c}\text { 12-item Briggs } \\
\& \text { Nebes } \\
\text { handedness } \\
\text { questionnaire }\end{array}$ & \\
\hline $\begin{array}{l}\text { Hicks \& } \\
\text { Kinsbourne } \\
\text { (1976) }\end{array}$ & 1,101 & 1,101 & 2,202 & USA & 9.36 & 9.36 & 9.36 & 9.36 & & & & & $\begin{array}{c}\text { Filial report of } \\
\text { writing hand }\end{array}$ & $\begin{array}{l}\text { Information about the } \\
\text { handedness of the } \\
\text { students was also } \\
\text { collected, but reported } \\
\text { only in the form of } \\
\text { laterality quotients. }\end{array}$ \\
\hline $\begin{array}{l}\text { Hicks, Pellegrini, } \\
\text { \& Evans (1978) }\end{array}$ & 366 & 362 & 728 & USA & 11.20 & 5.80 & 11.20 & 5.80 & & & & & $\begin{array}{c}\text { 12-item Briggs } \\
\& \text { Nebes } \\
\text { modification of } \\
\text { Annett's } \\
\text { questionnaire }\end{array}$ & $\begin{array}{l}\text { All ambidextrous } \\
\text { participants were } \\
\text { excluded from the } \\
\text { sample. }\end{array}$ \\
\hline Holder (1992) & 70 & 244 & 314 & USA & 10.00 & 9.02 & & & 10.00 & 9.02 & 25.71 & 19.26 & $\begin{array}{c}\text { Self- } \\
\text { classification }\end{array}$ & $\begin{array}{l}\text { Unpublished M.Phil } \\
\text { thesis }\end{array}$ \\
\hline Holtzen (1994) & 82 & 178 & 260 & USA & 4.88 & 8.43 & & & 4.88 & 8.43 & 2.44 & 1.12 & $\begin{array}{c}5 \text { items from the } \\
\text { EHI }\end{array}$ & $\begin{array}{l}\text { The participants were } \\
\text { controls to } \\
\text { homosexual } \\
\text { participants. }\end{array}$ \\
\hline Holtzen (2000) & 1,404 & 281 & 1,685 & - & 5.20 & 4.98 & 5.20 & 4.98 & & & & & $\begin{array}{l}\text { Hand holding } \\
\text { the racket }\end{array}$ & \\
\hline $\begin{array}{l}\text { Hoogmartens \& } \\
\text { Caubergh (1987) }\end{array}$ & 52 & 76 & 128 & Belgium & 11.54 & 7.89 & 11.54 & 7.89 & & & & & $\begin{array}{l}\text { The } 4 \text { items for } \\
\text { handedness } \\
\text { from the Lateral } \\
\text { Preference } \\
\text { Inventory by } \\
\text { Coren }\end{array}$ & \\
\hline Hoosain (1990) & 220 & 336 & 556 & $\begin{array}{l}\text { Hong } \\
\text { Kong }\end{array}$ & 2.73 & 0.89 & & & 2.73 & 0.89 & 5.45 & 1.79 & $\begin{array}{c}10-\text { item } \\
\text { questionnaire }\end{array}$ & \\
\hline $\begin{array}{l}\text { Huang \& Sejdić } \\
(2013)\end{array}$ & 9 & 11 & 20 & USA & 11.11 & 18.18 & & & 11.11 & 18.18 & 0.00 & 9.09 & EHI & \\
\hline Ida \& Bryden & 333 & 322 & 655 & Japan & 1.80 & 0.93 & 1.80 & 0.93 & & & & & Writing hand & $\begin{array}{l}\text { Data on } 65 \text { other items } \\
\text { as well, but no }\end{array}$ \\
\hline
\end{tabular}


HUMAN HANDEDNESS: A META-ANALYSIS

\begin{tabular}{|c|c|c|c|c|c|c|c|c|c|c|c|c|c|c|c|c|}
\hline (1996) & 245 & 375 & 620 & Canada & 9.80 & 7.73 & 9.80 & 7.73 & & & & & & & & $\begin{array}{l}\text { laterality quotient } \\
\text { given. }\end{array}$ \\
\hline $\begin{array}{l}\text { Inglis \& Lawson } \\
\text { (1984) }\end{array}$ & 940 & 940 & 1,880 & USA & 9.89 & 8.19 & 9.89 & 8.19 & & & & & & & $\begin{array}{l}\text { Three-item } \\
\text { questionnaire: } \\
\text { Self- } \\
\text { classification, } \\
\text { observation of } \\
\text { writing hand, } \\
\text { and hand usage }\end{array}$ & \\
\hline $\begin{array}{l}\text { Iwasaki, Kaiho, \& } \\
\text { Iseki (1995) }\end{array}$ & 696 & 1,059 & 1,755 & Japan & 1.15 & 0.66 & 1.15 & 0.66 & & & & & & & Writing hand & $\begin{array}{l}\text { Data also reported } \\
\text { from a 15-item } \\
\text { inventory. }\end{array}$ \\
\hline $\begin{array}{l}\text { Jung \& Jung } \\
\text { (2009) }\end{array}$ & 1,010 & 875 & 1,885 & Korea & 5.84 & 5.49 & & & 5.84 & 5.49 & 7.13 & 6.86 & & & $\begin{array}{c}\text { 13-item } \\
\text { handedness } \\
\text { questionnaire }\end{array}$ & $\begin{array}{l}\text { Participants from the } \\
\text { age group } 10-20 \text { yrs. } \\
\text { were excluded due to } \\
\text { the age criterion. Only } \\
1,885 \text { participants } \\
\text { remained. }\end{array}$ \\
\hline $\begin{array}{l}\text { Kalaycıoğlu, } \\
\text { Kara, Atbaşoğlu, } \\
\text { \& Nalçacı (2008) }\end{array}$ & 22 & 27 & 49 & Turkey & 4.55 & 14.81 & & & & & & & 4.55 & 14.81 & $\begin{array}{c}13 \text {-item } \\
\text { handedness } \\
\text { questionnaire } \\
\end{array}$ & \\
\hline $\begin{array}{l}\text { Kalichman, } \\
\text { Korostishevsky, } \\
\text { \& Kobyliansky } \\
(2015)\end{array}$ & 592 & 595 & 1,187 & Russia & 9.08 & 9.97 & 9.08 & 9.97 & & & & & & & $\begin{array}{c}\text { Writing hand, } \\
\text { observation of a } \\
\text { 3-item } \\
\text { handedness } \\
\text { performance } \\
\text { measure }\end{array}$ & $\begin{array}{l}\text { The writing hand was } \\
\text { taken into account for } \\
\text { the meta-analysis. }\end{array}$ \\
\hline \multirow{5}{*}{$\begin{array}{l}\text { Kauranen \& } \\
\text { Vanharanta } \\
\text { (1996) }\end{array}$} & 20 & 20 & 40 & \multirow{5}{*}{ Finland } & 0.00 & 10.00 & 0.00 & 10.00 & & & & & & & \multirow{5}{*}{$\begin{array}{c}\text { Self- } \\
\text { classification }\end{array}$} & \\
\hline & 20 & 20 & 40 & & 15.00 & 10.00 & 15.00 & 10.00 & & & & & & & & \\
\hline & 20 & 20 & 40 & & 5.00 & 15.00 & 5.00 & 15.00 & & & & & & & & \\
\hline & 20 & 20 & 40 & & 10.00 & 0.00 & 10.00 & 0.00 & & & & & & & & \\
\hline & 20 & 20 & 40 & & 5.00 & $\mathbf{0 . 0 0}$ & 5.00 & 0.00 & & & & & & & & \\
\hline Klum et al. (2012) & 387 & 363 & 750 & Germany & 6.72 & 6.06 & 6.72 & 6.06 & & & & & & & $\begin{array}{l}\text { Self- } \\
\text { classification } \\
\text { (in case of } \\
\text { uncertainty, the } \\
\text { writing hand } \\
\text { was taken into } \\
\text { account) }\end{array}$ & \\
\hline $\begin{array}{l}\text { Kuderer \& } \\
\text { Kirchengast } \\
(2016)\end{array}$ & 21 & 34 & 55 & Austria & 38.10 & 52.94 & & & 38.10 & 52.94 & 14.29 & 17.65 & & & $\begin{array}{l}\text { Observation of } \\
22 \text { activities }\end{array}$ & \\
\hline $\begin{array}{l}\text { Lai, Serra, } \\
\text { Petretto, Masala, } \\
\& \text { Preti (2014) }\end{array}$ & 506 & 517 & 1,023 & Italy & 10.87 & 9.67 & & & 10.87 & 9.67 & 1.19 & 1.35 & & & $\begin{array}{l}\text { Annett Hand } \\
\text { Preference } \\
\text { Questionnaire, } \\
\text { writing hand }\end{array}$ & $\begin{array}{l}\text { The writing hand } \\
\text { (reported as non- } \\
\text { corrected in the paper) } \\
\text { was taken into account } \\
\text { for the meta-analysis. }\end{array}$ \\
\hline
\end{tabular}


HUMAN HANDEDNESS: A META-ANALYSIS

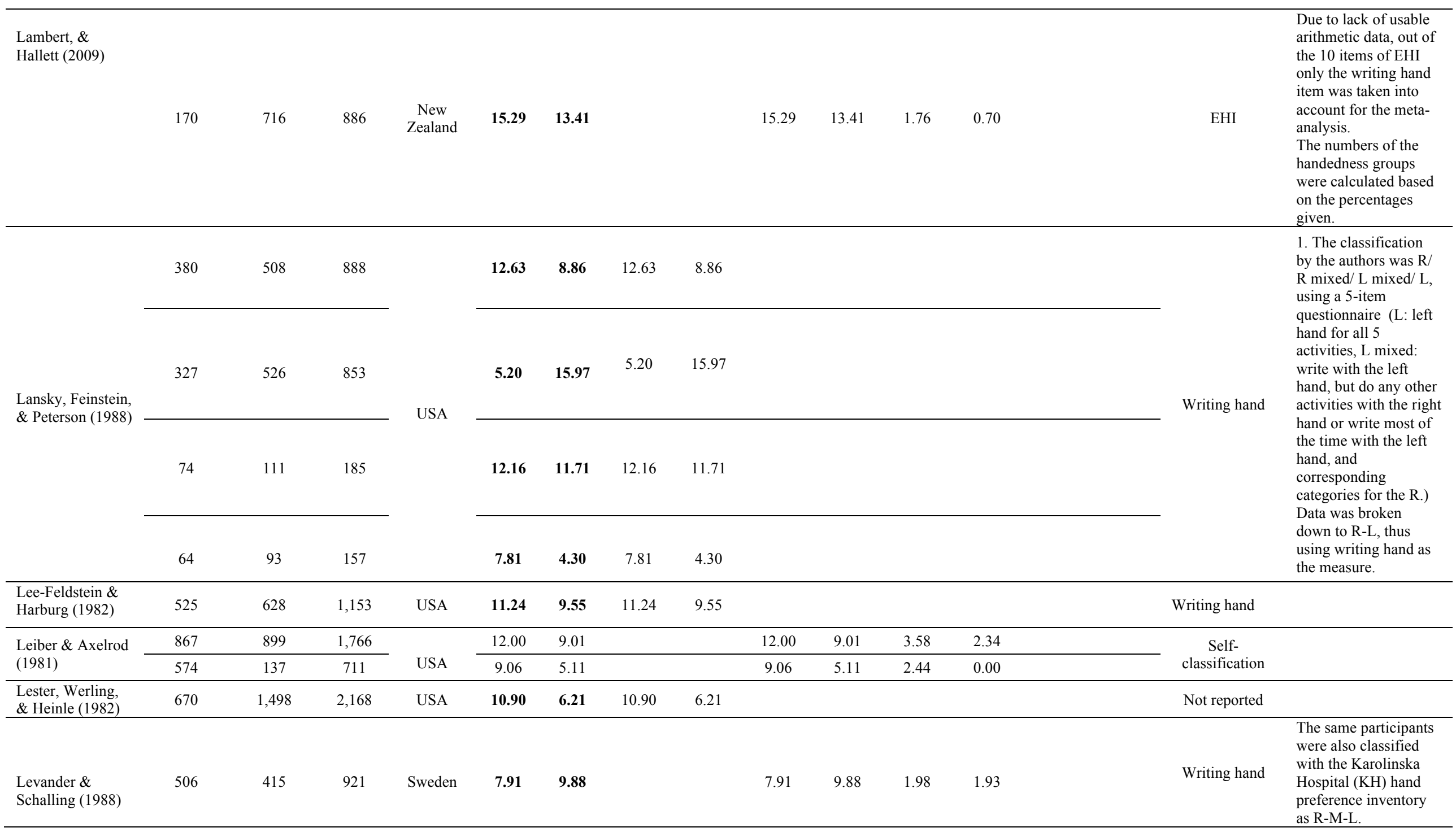


HUMAN HANDEDNESS: A META-ANALYSIS

\begin{tabular}{|c|c|c|c|c|c|c|c|c|c|c|c|c|}
\hline Lien, Chen, & 249 & 377 & 626 & Taiwan & 4.82 & 1.86 & 4.82 & 1.86 & & & \multirow{2}{*}{$\begin{array}{l}\text { Annett Hand } \\
\text { Preference } \\
\text { Questionnaire }\end{array}$} & \multirow{2}{*}{$\begin{array}{l}\text { Due to lack of usable } \\
\text { arithmetic data, out of } \\
\text { the } 10 \text { items of the } \\
\text { EHI only the writing } \\
\text { hand item was taken } \\
\text { into account for the } \\
\text { meta-analysis. } \\
\text { Two data sets (parents } \\
\text { and siblings) were } \\
\text { combined due to the } \\
\text { same variables. }\end{array}$} \\
\hline & 672 & 642 & 1,314 & Taiwan & 3.42 & 2.34 & 3.42 & 2.34 & & & & \\
\hline Lippa (2003) & 350 & 706 & 1,056 & USA & 11.43 & 12.04 & & & 11.43 & 12.04 & $\begin{array}{c}\text { Self- } \\
\text { classification/ } \\
\text { 3-item } \\
\text { inventory } \\
\end{array}$ & $\begin{array}{l}\text { The participants were } \\
\text { controls to } \\
\text { homosexual } \\
\text { participants. }\end{array}$ \\
\hline $\begin{array}{l}\text { Loffing, Sölter, \& } \\
\text { Hagemann (2014) }\end{array}$ & 408 & 495 & 903 & Germany & 10.05 & 7.88 & 10.05 & 7.88 & & & $\begin{array}{c}\text { EHI, Coren's } \\
\text { Lateral } \\
\text { Preference } \\
\text { Inventory }\end{array}$ & $\begin{array}{l}\text { The EHIwas taken into } \\
\text { account for the meta- } \\
\text { analysis. } \\
\text { The numbers of the } \\
\text { handedness groups } \\
\text { were calculated based } \\
\text { on the percentages } \\
\text { given. }\end{array}$ \\
\hline Loffing (2017) & 719 & 766 & 1,485 & $\begin{array}{c}\text { Not } \\
\text { reported }\end{array}$ & 15.44 & 10.70 & 15.44 & 10.70 & & & $\begin{array}{l}\text { Players' task- } \\
\text { specific } \\
\text { handedness } \\
\text { (i.e., throwing, } \\
\text { or holding a } \\
\text { racket) was } \\
\text { obtained from } \\
\text { websites or } \\
\text { from additional } \\
\text { pictures/videos } \\
\text { of players in } \\
\text { action } \\
\end{array}$ & $\begin{array}{l}\text { Only sports who } \\
\text { reported females' } \\
\text { handedness as well as } \\
\text { males' were taken into } \\
\text { account (badminton, } \\
\text { squash, table tennis, } \\
\text { tennis). }\end{array}$ \\
\hline $\begin{array}{l}\text { Lui, Baker, Nfila, } \\
\text { Perera, \& } \\
\text { Stephens (2012) }\end{array}$ & 57 & 5 & 62 & Ireland & 7.02 & 0.00 & 7.02 & 0.00 & & & $\begin{array}{c}\text { Waterloo } \\
\text { handedness } \\
\text { questionnaire, } \\
\text { Orthopaedic } \\
\text { Handedness } \\
\text { Questionnaire } \\
\end{array}$ & \\
\hline Lyle, Chapman, \& & 57 & 106 & 163 & USA & 64.91 & 33.02 & 64.91 & 33.02 & & & EHI & $\begin{array}{l}\text { Consistent and } \\
\text { inconsistent left- } \\
\text { handers were } \\
\text { considered to be one } \\
\text { class, the left-handers, } \\
\text { for the purposes of the }\end{array}$ \\
\hline
\end{tabular}


HUMAN HANDEDNESS: A META-ANALYSIS

\begin{tabular}{|c|c|c|c|c|c|c|c|c|c|c|c|c|}
\hline Hatton (2013) & & & & & & & & & & & & $\begin{array}{l}\text { meta-analysis. Also, } \\
\text { consistent and } \\
\text { inconsistent right- } \\
\text { handers were grouped } \\
\text { to form the right- } \\
\text { handedness class. }\end{array}$ \\
\hline $\begin{array}{l}\text { Maehara et } \\
\text { al.(1988) }\end{array}$ & 1,681 & 778 & 2,459 & Japan & 15.53 & 14.01 & & & 15.53 & 14.01 & 10-item EHI & $\begin{array}{l}\text { This study had } 8,693 \\
\text { participants from } 6 \text { to } \\
94 \text { years old. Only } \\
\text { reported here is the } \\
\text { percentage given for } \\
\text { the age group } 25-40, \\
\text { since the total average } \\
\text { could not be used, due } \\
\text { to the age limitation. }\end{array}$ \\
\hline $\begin{array}{l}\text { Marchant- } \\
\text { Haycox, } \\
\text { McManus, \& } \\
\text { Wilson (1991) }\end{array}$ & 287 & 109 & 396 & UK, USA & 7.67 & 6.42 & 7.67 & 6.42 & & & $\begin{array}{l}\text { 9-item hand } \\
\text { preference } \\
\text { inventory }\end{array}$ & $\begin{array}{l}\text { The participants were } \\
\text { controls to } \\
\text { homosexual } \\
\text { participants. }\end{array}$ \\
\hline $\begin{array}{l}\text { Marmolejo- } \\
\text { Ramos et al. } \\
\text { (2017) }\end{array}$ & 475 & 685 & 1160 & $\begin{array}{l}\text { England, } \\
\text { India, } \\
\text { Japan, } \\
\text { Spain, } \\
\text { Vietnam, } \\
\text { Germany }\end{array}$ & 14.11 & 8.32 & 14.11 & 8.32 & & & $\begin{array}{c}\text { Self- } \\
\text { classification }\end{array}$ & $\begin{array}{l}\text { Three data sets were } \\
\text { combined. }\end{array}$ \\
\hline $\begin{array}{l}\text { Martin \& Porac } \\
(2007)\end{array}$ & 731 & 904 & 1,635 & Brazil & 11.08 & 10.18 & 11.08 & 10.18 & & & $\begin{array}{c}\text { Self- } \\
\text { classification }\end{array}$ & $\begin{array}{l}\text { Participants were from } \\
\text { Brazil therefore not } \\
\text { fitting any of the three } \\
\text { ancestry categories } \\
\text { employed. Participants } \\
\text { also completed the } \\
\text { Paraense Lateral } \\
\text { Preference Inventory. }\end{array}$ \\
\hline $\begin{array}{l}\text { Mascie-Taylor, } \\
\text { MacLarnon, } \\
\text { Lanigan, \& } \\
\text { McManus (1981) }\end{array}$ & 79 & 62 & 141 & UK & 21.52 & 9.68 & 21.52 & 9.68 & & & Writing hand & \\
\hline $\begin{array}{l}\text { Mascie-Taylor } \\
(1980)\end{array}$ & 193 & 193 & 386 & UK & 8.81 & 7.25 & 8.81 & 7.25 & & & $\begin{array}{l}\text { Writing hand/ } \\
7 \text {-item } \\
\text { questionnaire }\end{array}$ & $\begin{array}{l}\text { The handedness of the } \\
\text { offspring was also } \\
\text { measured, but their } \\
\text { data were not } \\
\text { included, as they were } \\
\text { probably below } 16 \text {. }\end{array}$ \\
\hline $\begin{array}{l}\text { McFarland \& } \\
\text { Anderson (1980) }\end{array}$ & 85 & 96 & 181 & Australia & 7.06 & 5.21 & 7.06 & 5.21 & & & Writing hand & $\begin{array}{l}\text { Data on the other } \\
\text { items of the EHI } \\
\text { reported as well, but } \\
\text { no laterality quotient } \\
\text { given. }\end{array}$ \\
\hline
\end{tabular}


HUMAN HANDEDNESS: A META-ANALYSIS

\begin{tabular}{|c|c|c|c|c|c|c|c|c|c|c|c|c|c|c|c|c|}
\hline McGee (1976) & 46 & 66 & 112 & USA & 28.26 & 9.09 & 28.26 & 9.09 & & & & & & & $\begin{array}{c}7 \text { items from } \\
\text { Annett (1970) }\end{array}$ & \\
\hline $\begin{array}{l}\text { McGee \& Cozad } \\
(1980)\end{array}$ & 615 & 615 & 1,230 & USA & 19.67 & 16.75 & & & & & & & 19.67 & 16.75 & 10-item EHI & $\begin{array}{l}\text { Also data on the } \\
\text { students' and their } \\
\text { siblings' data, but } \\
\text { were not used, as the } \\
\text { siblings' age was not } \\
\text { reported. }\end{array}$ \\
\hline $\begin{array}{l}\text { McKeever \& Rich } \\
(1990)\end{array}$ & 1,116 & 1,964 & 3,080 & USA & 12.01 & 10.34 & 12.01 & 10.34 & & & & & & & Writing hand & \\
\hline McManus (1986) & 1,106 & 922 & 2,028 & UK & 10.04 & 10.74 & 10.04 & 10.74 & & & & & & & $\begin{array}{c}\text { Self- } \\
\text { classification }\end{array}$ & $\begin{array}{l}\text { Unpublished data } \\
\text { (Reported in } \\
\text { McManus, 2019). }\end{array}$ \\
\hline Merrell (1957) & $\begin{array}{c}72 \\
261 \\
\end{array}$ & \begin{tabular}{|l|}
51 \\
236 \\
\end{tabular} & $\begin{array}{ll}123 \\
497 \\
\end{array}$ & USA & $\begin{array}{l}4.17 \\
6.90 \\
\end{array}$ & \begin{tabular}{|l|}
3.92 \\
6.36 \\
\end{tabular} & $\begin{array}{l}4.17 \\
6.90 \\
\end{array}$ & \begin{tabular}{|l|}
3.92 \\
6.36 \\
\end{tabular} & & & & & & & Writing hand & \\
\hline $\begin{array}{l}\text { Mészáros et al. } \\
\text { (2006) }\end{array}$ & 44 & 106 & 150 & Hungary & 31.82 & 25.47 & 31.82 & 25.47 & & & & & & & $\begin{array}{c}\text { Structured } \\
\text { medical } \\
\text { questionnaire }\end{array}$ & \\
\hline $\begin{array}{l}\text { Milenković, } \\
\text { Brkić, \& } \\
\text { Belojević (2013) }\end{array}$ & 401 & 801 & 1,202 & Serbia & 7.73 & 3.62 & 7.73 & 3.62 & & & & & & & Writing hand & \\
\hline $\begin{array}{l}\text { Morley \& Caffrey } \\
\text { (1994) }\end{array}$ & 1,821 & 1,993 & 3,814 & UK & 11.97 & 11.34 & & & 11.97 & 11.34 & 0.27 & 0.25 & & & $\begin{array}{l}\text { Writing hand/ } \\
\text { self- } \\
\text { classification }\end{array}$ & \\
\hline $\begin{array}{l}\text { Mustanski, } \\
\text { Bailey, \& Kaspar } \\
\text { (2002) }\end{array}$ & 177 & 205 & 382 & USA & 10.17 & 9.76 & & & 10.17 & 9.76 & 2.82 & 0.00 & & & $\begin{array}{c}\text { Self- } \\
\text { classification }\end{array}$ & $\begin{array}{l}\text { The participants were } \\
\text { controls to } \\
\text { homosexual } \\
\text { participants. }\end{array}$ \\
\hline $\begin{array}{l}\text { Nalçaci, } \\
\text { Kalaycioğlu, } \\
\text { Çiçek, \& Genç } \\
\text { (2001) }\end{array}$ & 168 & 142 & 310 & Turkey & 36.31 & 19.72 & & & & & & & 36.31 & 19.72 & $\begin{array}{c}13 \text {-item } \\
\text { questionnaire } \\
\text { adapted from } \\
\text { Chapman \& } \\
\text { Chapman } \\
(1987) \\
\end{array}$ & \\
\hline Narr et al. (2007) & 30 & 37 & 67 & USA & 23.33 & 8.11 & & & & & & & 23.33 & 8.11 & $\begin{array}{c}\text { EHI, } \\
\text { observation }\end{array}$ & $\begin{array}{l}\text { The EHI was taken } \\
\text { into account for the } \\
\text { meta-analysis. }\end{array}$ \\
\hline
\end{tabular}


HUMAN HANDEDNESS: A META-ANALYSIS

\begin{tabular}{|c|c|c|c|c|c|c|c|c|c|c|c|c|c|c|c|c|}
\hline $\begin{array}{l}\text { Newcombe \& } \\
\text { Ratcliff (1973) }\end{array}$ & 409 & 414 & 823 & UK & 3.67 & 2.66 & & & 3.67 & 2.66 & 22.49 & 11.35 & & & $\begin{array}{c}\text { 7-item } \\
\text { questionnaire }\end{array}$ & \\
\hline $\begin{array}{l}\text { Newcombe et al. } \\
\text { (1975) }\end{array}$ & 462 & 466 & 928 & UK & 5.84 & 4.08 & & & 5.84 & 4.08 & 10.82 & 8.58 & & & $\begin{array}{l}\text { 7-item } \\
\text { questionnaire }\end{array}$ & $\begin{array}{l}\text { R: right hand preferred } \\
\text { for all items } \\
\text { L: left hand preferred } \\
\text { for all items } \\
\text { R/L: right hand and } \\
\text { left hand, each } \\
\text { preferred for at least } \\
\text { one item, but no either } \\
\text { hand responses } \\
\text { R/E: right-hand and } \\
\text { either hand, but no } \\
\text { left-hand responses } \\
\text { L/E: left-hand and } \\
\text { either-hand but no } \\
\text { right-hand responses } \\
\text { R/L/E: right-hand, } \\
\text { left-hand, and either - } \\
\text { hand, each reported for } \\
\text { at least one item. }\end{array}$ \\
\hline $\begin{array}{l}\text { Nicholls, Orr, } \\
\text { Yates, \& Loftus } \\
(2008)\end{array}$ & 131 & 469 & 600 & Australia & 12.98 & 10.23 & & & & & & & 12.98 & 10.23 & $\begin{array}{c}\text { Provins and } \\
\text { Cunliffe (1972) } \\
\text { questionnaire } \\
\end{array}$ & \\
\hline $\begin{array}{l}\text { Nicholls, } \\
\text { Chapman, } \\
\text { Loetscher, \& } \\
\text { Grimshaw (2010) } \\
\end{array}$ & 405 & 420 & 895 & $\mathrm{n} / \mathrm{a}$ & 9.14 & 7.38 & 9.14 & 7.38 & & & & & & & $\begin{array}{l}\text { Annett Hand } \\
\text { Preference } \\
\text { Questionnaire }\end{array}$ & $\begin{array}{l}\text { Calculations based on } \\
\text { raw data kindly } \\
\text { provided by the } \\
\text { authors. } \\
\end{array}$ \\
\hline $\begin{array}{l}\text { Nicholls, Thomas, } \\
\text { Loetscher, \& } \\
\text { Grimshaw (2013) }\end{array}$ & 754 & 2,570 & 3,324 & $\begin{array}{l}\text { Europe, } \\
\text { Asia }\end{array}$ & 9.42 & 8.09 & & & 9.42 & 8.09 & 3.32 & 1.79 & & & $\begin{array}{l}\text { Provins and } \\
\text { Cunliffe (1972) } \\
\text { questionnaire }\end{array}$ & $\begin{array}{l}\text { The numbers of the } \\
\text { handedness groups } \\
\text { were calculated based } \\
\text { on the percentages } \\
\text { given. }\end{array}$ \\
\hline $\begin{array}{l}\text { Obrzut, Dalby, } \\
\text { Boliek, \& Cannon } \\
\text { (1992) }\end{array}$ & 85 & 233 & 318 & USA & 11.76 & 8.15 & 11.76 & 8.15 & & & & & & & $\begin{array}{c}\text { The first factor } \\
\text { of the Waterloo } \\
\text { Handedness } \\
\text { Questionnaire } \\
\text { (14 items) }\end{array}$ & $\begin{array}{l}\text { The participants were } \\
\text { controls to learning- } \\
\text { disabled adults. }\end{array}$ \\
\hline \multirow{2}{*}{$\begin{array}{l}\text { Ocklenburg et al. } \\
\text { s (2016) }\end{array}$} & 103 & 103 & 206 & \multirow{2}{*}{ Germany } & 5.83 & 7.77 & 5.83 & 7.77 & & & & & & & \multirow{2}{*}{ EHI } & \multirow{2}{*}{$\begin{array}{l}\text { Calculations based on } \\
\text { raw data kindly } \\
\text { provided by the } \\
\text { authors. }\end{array}$} \\
\hline & 43 & 60 & 103 & & 11.63 & 8.33 & 11.63 & 8.33 & & & & & & & & \\
\hline Ofte (2002) & 153 & 240 & 393 & Norway & 13.73 & 14.17 & 13.73 & 14.17 & & & & & & & $\begin{array}{c}5 \text {-item } \\
\text { questionnaire } \\
\end{array}$ & \\
\hline Oldfield (1971) & 400 & 709 & 1,109 & UK & 10.00 & 5.92 & 10.00 & 5.92 & & & & & & & 10-item EHI & \\
\hline
\end{tabular}


HUMAN HANDEDNESS: A META-ANALYSIS

\begin{tabular}{|c|c|c|c|c|c|c|c|c|c|c|c|c|c|c|c|c|}
\hline Overby (1994) & 427 & 536 & 963 & USA & 8.43 & 7.84 & & & 8.43 & 7.84 & 6.56 & 2.80 & & & $\begin{array}{c}\text { Self- } \\
\text { classification }\end{array}$ & $\begin{array}{l}\text { The participants were } \\
\text { controls to college } \\
\text { students who obtained } \\
\text { elevated scores on the } \\
\text { BDI ("dysphoric"). }\end{array}$ \\
\hline $\begin{array}{l}\text { Perelle \& Ehrman } \\
\text { (1983) }\end{array}$ & 1,320 & 1,084 & 2,404 & USA & 20.38 & 19.56 & & & 20.38 & 19.56 & 4.32 & 5.81 & & & $\begin{array}{l}\text { 13-item } \\
\text { questionnaire }\end{array}$ & \\
\hline \multirow{2}{*}{$\begin{array}{l}\text { Perelle \& Ehrman } \\
\text { (1994) }\end{array}$} & 4,881 & 5,900 & 10,781 & 32 & 10.59 & 8.49 & 10.59 & 8.49 & & & & & & & \multirow{2}{*}{ Writing hand } & \\
\hline & 10,507 & 10,751 & 21,258 & countries & 5.71 & 5.75 & 5.71 & 5.75 & & & & & & & & \\
\hline $\begin{array}{l}\text { Peters, Petrie, \& } \\
\text { Oddie (1981) }\end{array}$ & 130 & 235 & 365 & Canada & 12.31 & 11.49 & & & & & & & 12.31 & 11.49 & $\begin{array}{c}\text { 4-item } \\
\text { questionnaire }\end{array}$ & \\
\hline $\begin{array}{l}\text { Peters, Reimers, } \\
\text { \& Manning } \\
\text { (2006) }\end{array}$ & 89,697 & 74,533 & $\begin{array}{c}164,23 \\
0\end{array}$ & UK & 12.66 & 10.50 & & & 12.66 & 10.50 & 0.56 & 0.76 & & & Writing hand & \\
\hline $\begin{array}{l}\text { Plato, Fox, \& } \\
\text { Garruto (1984) }\end{array}$ & 461 & 244 & 705 & USA & 6.94 & 4.10 & 6.94 & 4.10 & & & & & & & Writing hand & $\begin{array}{l}\text { Data also reported on } \\
\text { self-classification (R- } \\
\text { L) and a } 10 \text {-item } \\
\text { inventory (R-M-L). }\end{array}$ \\
\hline \multirow{4}{*}{ Porac (1993) } & 49 & 131 & 180 & \multirow{4}{*}{ Canada } & 8.16 & 12.21 & 8.16 & 12.21 & & & & & & & \multirow{4}{*}{$\begin{array}{c}\text { 6-item } \\
\text { questionnaire }\end{array}$} & \\
\hline & 78 & 154 & 232 & & 16.67 & 14.94 & 16.67 & 14.94 & & & & & & & & \\
\hline & 49 & 78 & 127 & & 10.20 & 5.13 & 10.20 & 5.13 & & & & & & & & \\
\hline & 42 & 51 & 93 & & 4.76 & 0.00 & 4.76 & 0.00 & & & & & & & & \\
\hline $\begin{array}{l}\text { Porac, Coren, \& } \\
\text { Searleman (1983) }\end{array}$ & 450 & 450 & 900 & Canada & 7.56 & 6.67 & 7.56 & 6.67 & & & & & & & Writing hand & $\begin{array}{l}\text { Also data from the } \\
\text { handedness of their } \\
\text { children was available } \\
\text { (R-L), but the age was } \\
\text { not reported. }\end{array}$ \\
\hline $\begin{array}{l}\text { Porfert \& } \\
\text { Rosenfield (1978) }\end{array}$ & 1,147 & 960 & 2,107 & USA & 14.56 & 13.96 & & & & & & & 14.56 & 13.96 & $\begin{array}{c}\text { Short } \\
\text { questionnaire }\end{array}$ & \\
\hline Preti et al. (2011) & 1,588 & 2,644 & 4,232 & Italy & 10.14 & 10.21 & & & 10.14 & 10.21 & 0.00 & 0.04 & & & Writing hand & \\
\hline Preti et al. (2012) & 419 & 585 & 1,004 & Italy & 8.59 & 9.57 & 8.59 & 9.57 & & & & & & & Writing hand & \\
\hline \multirow[t]{2}{*}{$\begin{array}{l}\text { Ravichandran, } \\
\text { Shinn, Öngür, } \\
\text { Perlis, \& Cohen } \\
\text { (2017) }\end{array}$} & 108 & 145 & 253 & USA & 10.19 & 7.59 & & & & & & & 10.19 & 7.59 & $\begin{array}{c}\text { Self- } \\
\text { classification }\end{array}$ & \\
\hline & 208 & 142 & 350 & France & 16.35 & 14.79 & 16.35 & 14.79 & & & & & & & $\begin{array}{c}\text { Students: } \\
\text { writing hand }\end{array}$ & \\
\hline $\begin{array}{l}\text { Raymond, } \\
\text { Pontier, Dufour, } \\
\& \text { Moller (1996) }\end{array}$ & 274 & 268 & 542 & $\mathrm{n} / \mathrm{a}$ & 16.42 & 11.19 & 16.42 & 11.19 & & & & & & & $\begin{array}{c}\text { Athletes: hand } \\
\text { holding discus, } \\
\text { javelin, shot put } \\
\text { or racket }\end{array}$ & \\
\hline
\end{tabular}


HUMAN HANDEDNESS: A META-ANALYSIS

\begin{tabular}{|c|c|c|c|c|c|c|c|c|c|c|c|c|c|c|c|c|}
\hline & 42 & 33 & 75 & France & 21.43 & 18.18 & 21.43 & 18.18 & & & & & & & $\begin{array}{l}\text { Athletes: hand } \\
\text { holding discus, } \\
\text { javelin, shot } \\
\text { put, or racket }\end{array}$ & \\
\hline $\begin{array}{l}\text { Reina, Cavaignac, } \\
\text { Trousdale, } \\
\text { Laffosse, \& } \\
\text { Braga (2017) } \\
\end{array}$ & 11 & 6 & 17 & $\mathrm{n} / \mathrm{a}$ & 18.18 & 16.67 & 18.18 & 16.67 & & & & & & & $\begin{array}{c}\text { Self- } \\
\text { classification }\end{array}$ & \\
\hline $\begin{array}{l}\text { Reiss \& Reiss } \\
\text { (1997) }\end{array}$ & 506 & 430 & 936 & Germany & 11.26 & 6.05 & & & & & & & 11.26 & 6.05 & $\begin{array}{l}\text { The } 4 \text { items for } \\
\text { handedness } \\
\text { from the Lateral } \\
\text { Preference } \\
\text { Inventory by } \\
\text { Coren }\end{array}$ & \\
\hline Reiss et al. (1998) & 556 & 667 & 1,223 & Germany & 7.91 & 7.05 & & & 7.91 & 7.05 & 3.06 & 1.95 & & & $\begin{array}{c}\text { Self- } \\
\text { classification }\end{array}$ & $\begin{array}{l}\text { Data also on 10-item } \\
\text { EHI (R-M-L). }\end{array}$ \\
\hline \multirow{2}{*}{ Rife (1940) } & 1,282 & 896 & 2,178 & \multirow{2}{*}{ USA } & 9.59 & 7.59 & & & & & & & 9.59 & 7.59 & \multirow{2}{*}{$\begin{array}{l}\text { 10-item } \\
\text { questionnaire }\end{array}$} & \multirow{2}{*}{$\begin{array}{l}\text { It was not known how } \\
\text { many were the } \\
\text { students and how } \\
\text { many were the } \\
\text { siblings. }\end{array}$} \\
\hline & 687 & 687 & 1,374 & & 5.39 & 5.09 & & & & & & & 5.39 & 5.09 & & \\
\hline \multirow{2}{*}{$\begin{array}{l}\text { Risch \& Pringle } \\
\text { (1985) }\end{array}$} & 2,122 & 2,141 & 4,263 & \multirow{2}{*}{ USA } & 13.05 & 11.86 & 13.05 & 11.86 & & & & & & & \multirow{2}{*}{$\begin{array}{l}\text { Offspring: 10- } \\
\text { item EHI and } \\
\text { self- } \\
\text { classification }\end{array}$} & \multirow{2}{*}{$\begin{array}{l}\text { Among the } \\
\text { participants it was not } \\
\text { clear who were the } \\
\text { students i.e. the } \\
\text { reporter and who were } \\
\text { the siblings }\end{array}$} \\
\hline & 1,564 & 1,564 & 3,128 & & 12.34 & 7.29 & 12.34 & 7.29 & & & & & & & & \\
\hline $\begin{array}{l}\text { Robinson, Hurd, } \\
\text { Read, \& Crespi } \\
(2016)\end{array}$ & 233 & 475 & 708 & Canada & 6.87 & 5.68 & & & 6.87 & 5.68 & 8.58 & 8.21 & & & $\begin{array}{c}\text { Waterloo } \\
\text { handedness } \\
\text { questionnaire }\end{array}$ & \\
\hline $\begin{array}{l}\text { Rosenstein \& } \\
\text { Bigler (1987) }\end{array}$ & 14 & 36 & 50 & USA & 7.14 & 5.56 & 7.14 & 5.56 & & & & & & & 10-item EHI & $\begin{array}{l}\text { The participants were } \\
\text { controls to } \\
\text { homosexual } \\
\text { participants. }\end{array}$ \\
\hline \multirow{2}{*}{$\begin{array}{l}\text { Sakano \& } \\
\text { Pickenhain (1985) }\end{array}$} & 399 & 599 & 998 & Japan & 5.26 & 2.84 & & & 5.26 & 2.84 & 6.77 & 6.68 & & & \multirow{2}{*}{$\begin{array}{l}5 \text { items from the } \\
\text { EHI }\end{array}$} & \multirow{2}{*}{$\begin{array}{l}\text { It was not clear how } \\
\text { the participants } \\
\text { scoring } 60-80 \text { or }(-20)- \\
0 \text { were classified; } \\
\text { possibly they were } \\
\text { excluded from the } \\
\text { sample. }\end{array}$} \\
\hline & 235 & 455 & 690 & Germany & 7.66 & 2.42 & & & 7.66 & 2.42 & 8.94 & 7.91 & & & & \\
\hline $\begin{array}{l}\text { Salmaso \& } \\
\text { Longoni (1985) }\end{array}$ & 961 & 733 & 1,694 & Italy & 6.76 & 6.41 & 6.76 & 6.41 & & & & & & & 20-item EHI & \\
\hline \multirow[b]{3}{*}{ Sanders, Wilson, } & 173 & 168 & 341 & \multirow{3}{*}{$\begin{array}{l}\text { USA } \\
\text { (Euro- } \\
\text { pean, }\end{array}$} & 5.78 & 7.14 & & & 5.78 & 7.14 & 17.92 & 13.10 & & & \multirow{3}{*}{$\begin{array}{c}\text { Hand } \\
\text { preference } \\
\text { questionnaire }\end{array}$} & \\
\hline & 110 & 114 & 224 & & 7.27 & 6.14 & & & 7.27 & 6.14 & 26.36 & 15.79 & & & & \\
\hline & 67 & 76 & 143 & & 4.48 & 1.32 & & & 4.48 & 1.32 & 20.90 & 10.53 & & & & \\
\hline
\end{tabular}


HUMAN HANDEDNESS: A META-ANALYSIS

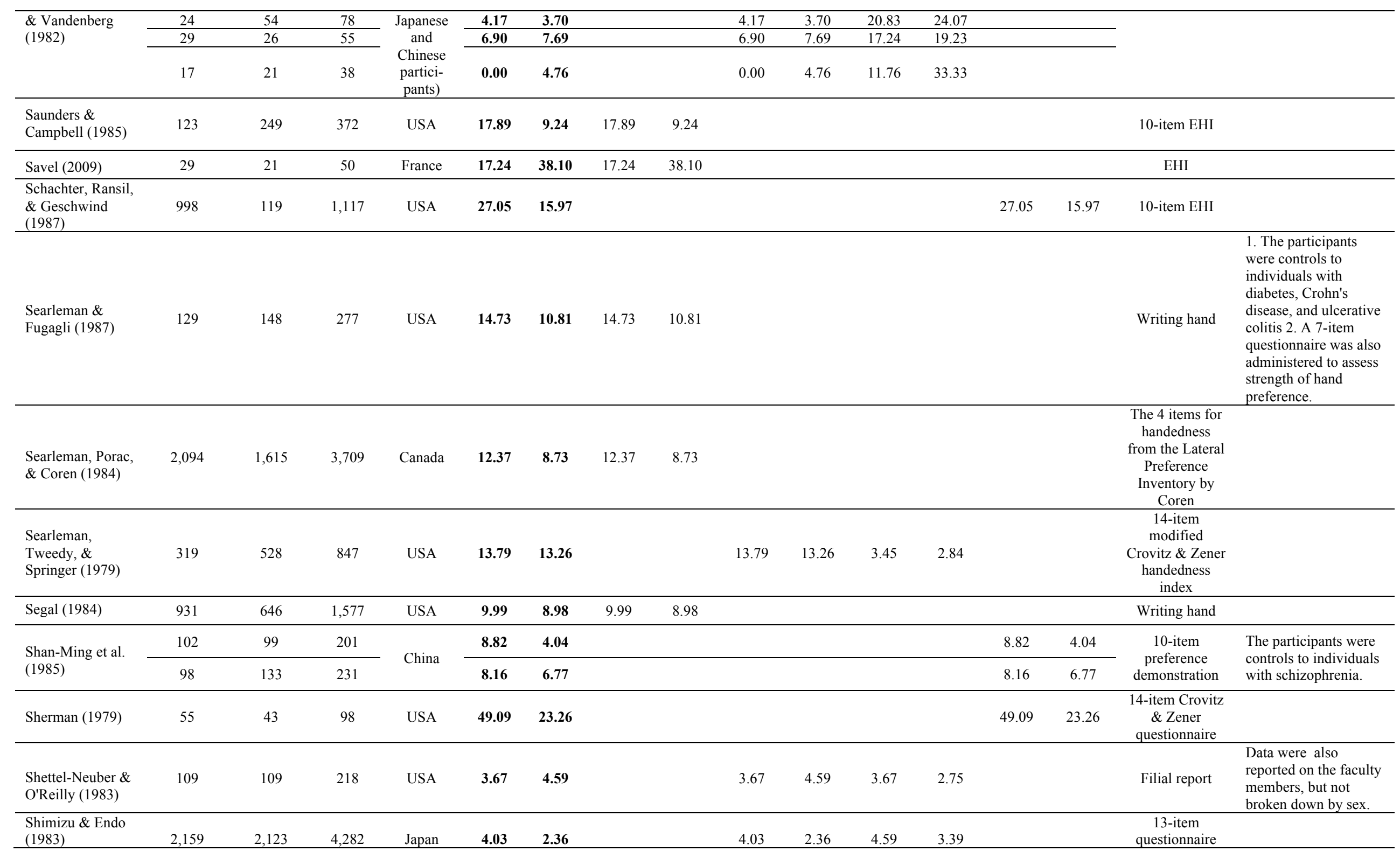


HUMAN HANDEDNESS: A META-ANALYSIS

\begin{tabular}{|c|c|c|c|c|c|c|c|c|c|c|c|c|c|c|c|c|}
\hline $\begin{array}{l}\text { Singh \& Bryden } \\
\text { (1994) }\end{array}$ & 278 & 451 & 729 & India & 10.79 & 6.87 & 10.79 & 6.87 & & & & & & & $\begin{array}{l}\text { The first factor } \\
\text { from the } 59- \\
\text { item version of } \\
\text { the Waterloo } \\
\text { Handedness } \\
\text { Questionnaire } \\
\text { (10-items) }\end{array}$ & \\
\hline Smith (1987) & 164 & 186 & 350 & UK & 10.98 & 6.99 & 10.98 & 6.99 & & & & & & & 10-item EHI & $\begin{array}{l}\text { The participants were } \\
\text { controls to allergic } \\
\text { patients, matched for } \\
\text { age and sex. }\end{array}$ \\
\hline $\begin{array}{l}\text { Spiegler \& Yeni- } \\
\text { Komshian (1983) }\end{array}$ & $\begin{array}{c}810 \\
1,816 \\
\end{array}$ & $\begin{array}{l}1,006 \\
1,816 \\
\end{array}$ & $\begin{array}{l}1,816 \\
3,632 \\
\end{array}$ & USA & \begin{tabular}{ll|}
15.19 \\
10.19 \\
\end{tabular} & $\begin{array}{c}12.62 \\
8.20 \\
\end{array}$ & $\begin{array}{l}15.19 \\
10.19 \\
\end{array}$ & $\begin{array}{c}12.62 \\
8.20 \\
\end{array}$ & & & & & & & Writing hand & \\
\hline $\begin{array}{l}\text { Stoyanov, } \\
\text { Nikolova, \& } \\
\text { Pashalieva (2011) }\end{array}$ & 1,530 & 1,652 & 3,182 & Bulgaria & 13.66 & 8.96 & & & & & & & 13.66 & 8.96 & $\begin{array}{c}\text { Annett Hand } \\
\text { Preference } \\
\text { Questionnaire, } \\
\text { EHI } \\
\end{array}$ & \\
\hline $\begin{array}{l}\text { Suar, Mandal, } \\
\text { Misra, \& Suman } \\
\text { (2013) }\end{array}$ & 2,822 & 876 & 3,698 & India & 4.15 & 3.42 & 4.15 & 3.42 & & & & & & & $\begin{array}{c}\text { 13-item } \\
\text { handedness } \\
\text { questionnaire, } \\
\text { writing hand (1 } \\
\text { of the 13) }\end{array}$ & $\begin{array}{l}\text { Writing hand was } \\
\text { taken into account for } \\
\text { the meta-analysis. } \\
\\
\text { Even though the age } \\
\text { range was } 9-83 \text { years, } \\
\text { the study was included } \\
\text { because the majority } \\
\text { of the participants was } \\
\text { within our age } \\
\text { criterion (mean age for } \\
\text { males } 30,18 \\
\mathrm{SD}=16,57 \text { ) }\end{array}$ \\
\hline Tan (1986) & 173 & 93 & 266 & Turkey & 7.51 & 0.00 & & & 7.51 & 0.00 & 31.79 & 24.73 & & & $\begin{array}{c}\text { 12-item Annett } \\
\text { Handedness } \\
\text { questionnaire }\end{array}$ & \\
\hline Tan (1988) & 750 & 350 & 1,100 & Turkey & 3.07 & 4.00 & & & 3.07 & 4.00 & 32.80 & 26.00 & & & $\begin{array}{c}\text { Turkish } \\
\text { adaptation of } \\
\text { the EHI }\end{array}$ & \\
\hline $\begin{array}{l}\text { Tapley \& Bryden } \\
(1985)\end{array}$ & 687 & 824 & 1,511 & Canada & 11.50 & 9.71 & 11.50 & 9.71 & & & & & & & $\begin{array}{c}8 \text {-item } \\
\text { questionnaire }\end{array}$ & \\
\hline $\begin{array}{l}\text { Teng, Lee, Yang, } \\
\& \text { Chang (1979) }\end{array}$ & 1,025 & 1,016 & 2,041 & Taiwan & 5.95 & 2.95 & 5.95 & 2.95 & & & & & & & 12-item EHI & $\begin{array}{l}\text { Another } 2,102 \text { subjects } \\
\text { were tested, but their } \\
\text { mean age was } 11 \text { yr., } \\
\text { so they were excluded. } \\
\text { The percentages of } \\
\text { handedness though, } \\
\text { have been calculated } \\
\text { for the whole sample, } \\
\text { but no significant }\end{array}$ \\
\hline
\end{tabular}


HUMAN HANDEDNESS: A META-ANALYSIS

\begin{tabular}{|c|c|c|c|c|c|c|c|c|c|c|c|c|c|c|c|c|}
\hline & & & & & & & & & & & & & & & & $\begin{array}{l}\text { differences were } \\
\text { reported between the } \\
\text { school \& university } \\
\text { sample. }\end{array}$ \\
\hline $\begin{array}{l}\text { Thompson \& } \\
\text { Marsh (1976) }\end{array}$ & 669 & 630 & 1,299 & USA & 5.53 & 3.17 & & & 5.53 & 3.17 & 35.72 & 29.52 & & & $\begin{array}{c}\text { 4-item } \\
\text { questionnaire }\end{array}$ & \\
\hline $\begin{array}{l}\text { Tonetti, Adan, } \\
\text { Caci, Fabbri, \& } \\
\text { Natale (2012) }\end{array}$ & 1,353 & 2,120 & 3,473 & $\begin{array}{l}\text { Spain, } \\
\text { Italy, } \\
\text { France }\end{array}$ & 11.53 & 7.88 & 11.53 & 7.88 & & & & & & & EHI & \\
\hline $\begin{array}{l}\text { Tran, Stieger, \& } \\
\text { Voracek (2014) }\end{array}$ & 5,515 & 7,205 & 12,720 & $\begin{array}{l}\text { Austria, } \\
\text { Germany }\end{array}$ & 8.83 & 7.48 & & & 8.83 & 7.48 & 2.47 & 2.23 & & & $\begin{array}{c}\text { 12-item } \\
\text { handedness } \\
\text { questionnaire }\end{array}$ & $\begin{array}{l}\text { Two data sets } \\
\text { (discovery and } \\
\text { replication sample) } \\
\text { were combined. } \\
\end{array}$ \\
\hline $\begin{array}{l}\text { Tsuang, Chen, } \\
\text { Kuo, \& Hsiao } \\
(2016)\end{array}$ & 1,597 & 1,848 & 3,445 & Taiwan & 5.32 & 3.63 & 5.32 & 3.63 & & & & & & & $\begin{array}{l}\text { Annett Hand } \\
\text { Preference } \\
\text { Questionnaire } \\
\text { (Briggs \& } \\
\text { Nebes, 1975), } \\
\text { writing hand }\end{array}$ & $\begin{array}{l}\text { Writing hand was } \\
\text { taken into account for } \\
\text { the meta-analysis. }\end{array}$ \\
\hline $\begin{array}{l}\text { Walker \& } \\
\text { Henneberg (2007) }\end{array}$ & 8 & 13 & 21 & Australia & 0.00 & 15.38 & & & 0.00 & 15.38 & 25.00 & 7.69 & & & EHI & $\begin{array}{l}\text { There were } 7 \\
\text { handedness groups. } \\
\text { The intermediate } \\
\text { classes were grouped } \\
\text { to form the mixed- } \\
\text { handedness class for } \\
\text { the purposes of the } \\
\text { meta-analysis. }\end{array}$ \\
\hline $\begin{array}{l}\text { Wolf, D'Agostino, } \\
\& \text { Cobb (1991) }\end{array}$ & 869 & 1,219 & 2,088 & USA & 9.78 & 8.45 & 9.78 & 8.45 & & & & & & & Interview & \\
\hline $\begin{array}{l}\text { Wood \& Aggleton } \\
\text { (1989) }\end{array}$ & 500 & 252 & 752 & UK & 12.20 & 11.90 & & & 12.20 & 11.90 & 2.00 & 3.97 & & & $\begin{array}{l}\text { Hand used to } \\
\text { hold a racket }\end{array}$ & \\
\hline $\begin{array}{l}\text { Wood \& Aggleton } \\
\text { (1991) }\end{array}$ & 842 & 398 & 1,240 & UK & 11.21 & 6.61 & 11.21 & 6.61 & & & & & & & 10-item EHI & \\
\hline $\begin{array}{l}\text { Xu \& Zheng } \\
(2017)\end{array}$ & 392 & 554 & 946 & China & 6.12 & 4.87 & & & 6.12 & 4.87 & 11.22 & 10.65 & & & Writing hand & $\begin{array}{l}\text { The subgroup that was } \\
\text { selected was that of } \\
\text { the heterosexual } \\
\text { individuals according } \\
\text { to sexual attraction, } \\
\text { not sexual behavior or } \\
\text { identity. }\end{array}$ \\
\hline You et al. (2013) & 21 & 19 & 40 & Korea & 23.81 & 26.32 & & & & & & & & & $\begin{array}{c}\text { Self- } \\
\text { classification }\end{array}$ & $\begin{array}{l}\text { Calculations based on } \\
\text { raw data kindly } \\
\text { provided by the } \\
\text { authors. }\end{array}$ \\
\hline $\begin{array}{l}\text { Yule, Brotto, \& } \\
\text { Gorzalka (2015) }\end{array}$ & 190 & 500 & 690 & $\begin{array}{c}52 \% \\
\text { European } \\
32 \% \text { East } \\
\text { Asian } \\
\end{array}$ & 13.16 & 12.00 & & & & & & & 13.16 & 12.00 & EHI & $\begin{array}{l}\text { The numbers of the } \\
\text { handedness groups } \\
\text { were calculated based } \\
\text { on the percentages }\end{array}$ \\
\hline
\end{tabular}


HUMAN HANDEDNESS: A META-ANALYSIS

$16 \%$ other

\begin{tabular}{|c|c|c|c|c|c|c|c|c|c|c|c|c|}
\hline & & & & $16 \%$ other & & & & & & & & given. \\
\hline Zhu et al. (2009) & 9,234 & 9,234 & 18,468 & Denmark & 7.94 & 6.92 & 7.94 & 6.92 & 4.53 & 2.79 & $\begin{array}{l}\text { Self-report } \\
\text { ("Which hand } \\
\text { do you use the } \\
\text { most?") }\end{array}$ & $\begin{array}{l}\text { Strong dextrals and } \\
\text { dextrals were } \\
\text { considered to be one } \\
\text { class, the right- } \\
\text { handers, for the } \\
\text { purposes of the meta- } \\
\text { analysis. Also, strong } \\
\text { sinistrals and sinistrals } \\
\text { were grouped to form } \\
\text { the left-handedness } \\
\text { class. } \\
\text { Two studies (Aalborg- } \\
\text { Odense Birth Cohort } \\
\text { study and Aarhus } \\
\text { Birth Cohort study) } \\
\text { were combined. }\end{array}$ \\
\hline
\end{tabular}


Table 2.

Incidence of Left-Handedness in the Different Levels of the Moderator Variables Within the Left-Handedness (Total) Comparison

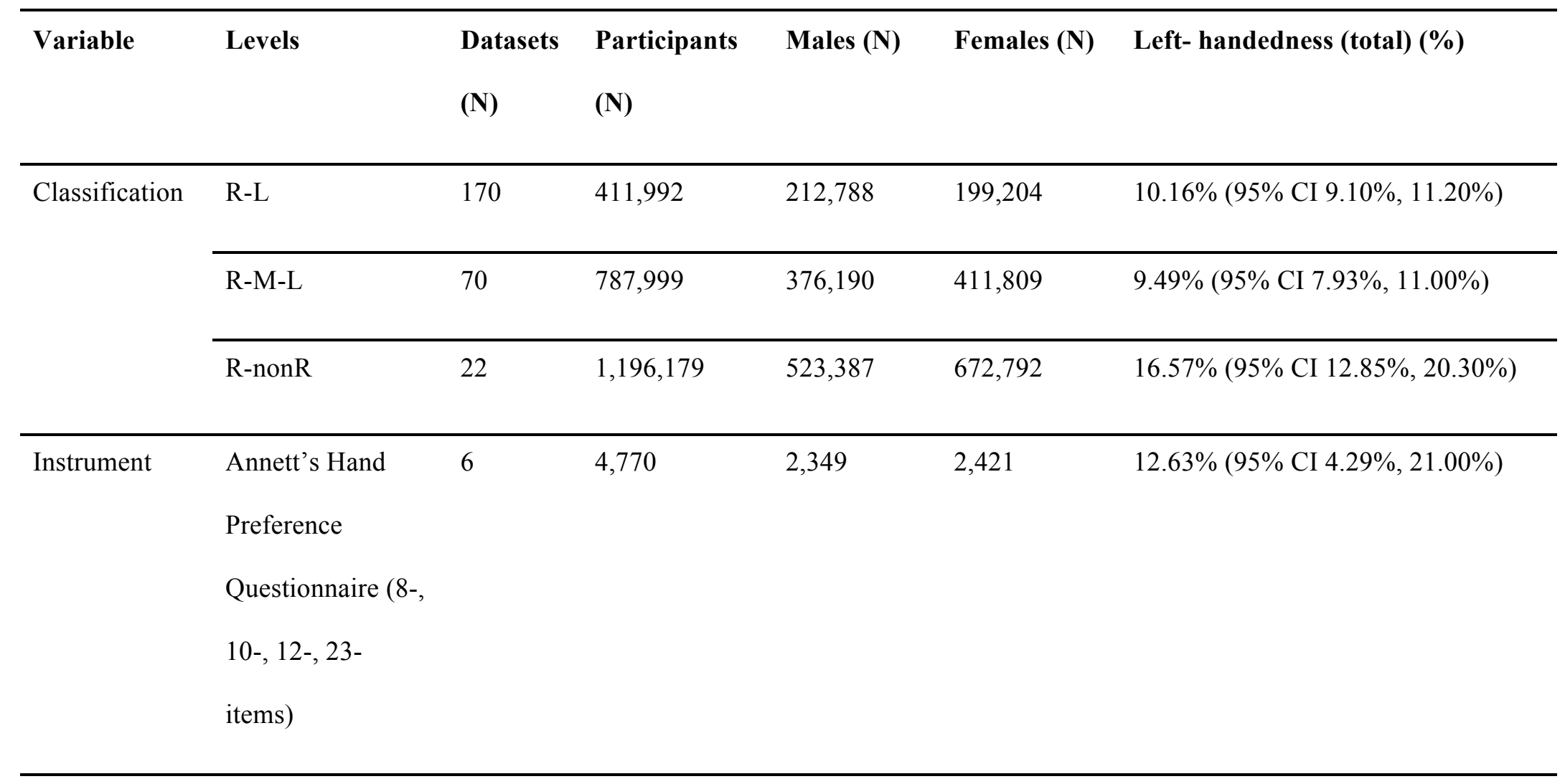


HUMAN HANDEDNESS: A META-ANALYSIS

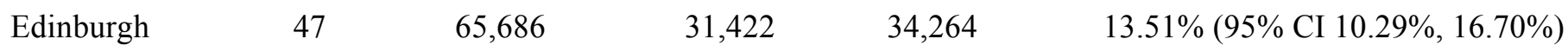

Handedness

Inventory (10-

items)

\begin{tabular}{|c|c|c|c|c|c|}
\hline Writing hand & 71 & 436,921 & 232,855 & 204,066 & $9.29 \%(95 \%$ CI $8.45 \%, 10.10 \%)$ \\
\hline Self-classification & 29 & 575,588 & 263,722 & 311,866 & $9.24 \%(95 \%$ CI $8.07 \%, 10.40 \%)$ \\
\hline \multicolumn{6}{|l|}{ ('Are you right-, } \\
\hline \multicolumn{6}{|l|}{ (mixed-), or left- } \\
\hline \multicolumn{6}{|l|}{ handed?') } \\
\hline Briggs \& Nebes & 6 & 5,562 & 2,972 & 2,590 & $9.73 \%(95 \%$ CI $8.23 \%, 11.20 \%)$ \\
\hline
\end{tabular}

Questionnaire 
HUMAN HANDEDNESS: A META-ANALYSIS

4 items on $\quad 9 \quad 18,210 \quad 8,620 \quad 9,590 \quad 9.75 \%(95 \%$ CI $8.95 \%, 10.50 \%)$

handedness from

Coren \& Porac's

Laterality

Inventory

Observatio

15

$15.11 \%(95 \%$ CI $9.15 \%, 21.10 \%)$

\begin{tabular}{|c|c|c|c|c|c|c|}
\hline \multirow{4}{*}{$\begin{array}{l}\text { Number of } \\
\text { questionnaire } \\
\text { items }\end{array}$} & 1 & 118 & $1,024,509$ & 504,192 & 520,317 & $9.66 \%(95 \%$ CI $8.84 \%, 10.50 \%)$ \\
\hline & $2-9$ & 31 & $1,218,679$ & 536,505 & 682,174 & $10.15 \%(95 \%$ CI $8.23 \%, 12.10 \%)$ \\
\hline & $10-15$ & 87 & 116,467 & 56,000 & 60,467 & $11.93 \%(95 \%$ CI $9.1 \%, 14.10 \%)$ \\
\hline & $>15$ & 7 & 6,336 & 2,234 & 4,102 & $12.82 \%(95 \%$ CI $4.00 \%, 21.60 \%)$ \\
\hline \multirow{3}{*}{$\begin{array}{l}\text { Response } \\
\text { format }\end{array}$} & R-L & 44 & $1,376,363$ & 620,670 & 755,693 & $9.83 \%(95 \%$ CI $8.05 \%, 11.60 \%)$ \\
\hline & R-M-L & 79 & 639,165 & 294,623 & 344,542 & $10.34 \%(95 \%$ CI $9.01 \%, 11.70 \%)$ \\
\hline & 5-point scale & 40 & 218,262 & 117,564 & 100,698 & $11.26 \%(95 \%$ CI $8.07 \%, 14.40 \%)$ \\
\hline
\end{tabular}


HUMAN HANDEDNESS: A META-ANALYSIS

\begin{tabular}{|c|c|c|c|c|c|c|}
\hline & + or ++ & 10 & 29,814 & 13,529 & 16,285 & $10.50 \%(95 \%$ CI $5.98 \%, 15.00 \%)$ \\
\hline \multirow{2}{*}{$\begin{array}{l}\text { Main purpose } \\
\text { of the study to } \\
\text { measure } \\
\text { handedness }\end{array}$} & Yes & 161 & $2,123,344$ & 965,955 & $1,157,389$ & $10.10 \%(95 \%$ CI $8.88 \%, 11.30 \%)$ \\
\hline & No & 100 & 270,798 & 145,304 & 125,494 & $11.40 \%(95 \%$ CI $10.11 \%, 12.70 \%)$ \\
\hline \multirow{5}{*}{$\begin{array}{l}\text { Year of } \\
\text { publication }\end{array}$} & $<1976$ & 18 & 27,568 & 14,346 & 13,222 & $7.19 \%(95 \%$ CI $5.62 \%, 8.76 \%)$ \\
\hline & $1976-1985$ & 69 & 76,287 & 37,747 & 38,540 & $10.73 \%(95 \%$ CI $8.81 \%, 12.65 \%)$ \\
\hline & 1986-1995 & 70 & $1,302,927$ & 573,093 & 729,834 & $10.64 \%(95 \%$ CI $8.90 \%, 12.38 \%)$ \\
\hline & $1996-2007$ & 46 & 381,594 & 206,743 & 174,851 & $11.70 \%(95 \%$ CI $9.57 \%, 13.82 \%)$ \\
\hline & $2008-2019$ & 57 & 607,487 & 280,259 & 327,228 & $10.77 \%(95 \%$ CI $8.62 \%, 12.92 \%)$ \\
\hline \multirow[t]{2}{*}{ Report } & Self-report & 232 & $2,329,356$ & $1,078,002$ & $1,251,354$ & $10.50 \%(95 \%$ CI $9.58 \%, 11.40 \%)$ \\
\hline & Not self-report & 28 & 55,263 & 28,597 & 26,666 & $11.90 \%(95 \%$ CI $8.22 \%, 15.60 \%)$ \\
\hline Ancestry & European & 184 & $1,738,827$ & 808,191 & 930,636 & $11.12 \%(95 \%$ CI $10.09 \%, 12.15 \%)$ \\
\hline
\end{tabular}


HUMAN HANDEDNESS: A META-ANALYSIS

\begin{tabular}{llllll}
\hline sub-Sahara & 9 & 4,645 & 2,338 & 2,307 & $7.71 \%(95 \%$ CI $6.25 \%, 9.18 \%)$
\end{tabular}

African

\begin{tabular}{|c|c|c|}
\hline East Asian & 23 & $5.69 \%(95 \%$ CI $3.49 \%, 7.88 \%)$ \\
\hline
\end{tabular}

\begin{tabular}{lllllll}
\hline Sporting elite & Yes & 12 & 9,301 & 5,755 & 3,546 & $14.70 \%(95 \%$ CI 9.72\%, 19.80\%) \\
\cline { 2 - 6 } & No & 250 & $2,386,869$ & $1,106,610$ & $1,280,259$ & $10.40 \%(95 \%$ CI $9.52 \%, 11.30 \%)$ \\
\hline \multirow{2}{*}{ Education } & High & 101 & 94,661 & 44,166 & 50,495 & $11.40 \%(95 \%$ CI 9.86\%, 12.90\%) \\
\cline { 2 - 6 } & Average & 142 & $2,256,509$ & $1,045,055$ & $1,211,454$ & $10.10 \%(95 \%$ CI $8.92 \%, 11.30 \%)$
\end{tabular}


Table 3.

Overall Incidence of Left-Handedness in the Data Sets

\begin{tabular}{|c|c|c|c|c|c|}
\hline Comparison & $\begin{array}{l}\text { Number } \\
\text { of data } \\
\text { sets }\end{array}$ & $\begin{array}{l}\text { Number of } \\
\text { Participants }\end{array}$ & $\begin{array}{l}\text { Number of } \\
\text { Males }\end{array}$ & $\begin{array}{l}\text { Number of } \\
\text { Females }\end{array}$ & $\begin{array}{l}\text { Overall Incidence } \\
(\%, 95 \% \mathrm{CI})\end{array}$ \\
\hline $\begin{array}{l}\text { Left-handedness } \\
\text { (stringent) }\end{array}$ & 72 & 789,090 & 376,844 & 412,246 & $9.34 \%(95 \% \mathrm{CI}=7.92 \%, 10.80 \%)$ \\
\hline $\begin{array}{l}\text { Left-handedness (forced } \\
\text { choice) }\end{array}$ & 173 & 413,560 & 213,494 & 200,066 & $10.20 \%(95 \% \mathrm{CI}=9.14 \%, 11.20 \%)$ \\
\hline Non-right-handedness & 26 & $1,203,403$ & 526,622 & 676,781 & $18.10 \%(95 \% \mathrm{CI}=13.90 \%, 22.30 \%)$ \\
\hline Mixed-handedness & 72 & 789,090 & 376,844 & 412,246 & $9.33 \%(95 \% \mathrm{CI}=6.67 \%, 12.00 \%)$ \\
\hline Left-handedness (total) & 262 & $2,396,170$ & $1,112,365$ & $1,283,805$ & $10.60 \%(95 \% \mathrm{CI}=9.71 \%, 11.50 \%)$ \\
\hline
\end{tabular}


Table 4.

Moderator Variables Extracted From Each Study

\begin{tabular}{|c|c|c|c|c|c|c|c|c|c|c|}
\hline Study & $\begin{array}{l}\text { Total } \\
(N)\end{array}$ & $\begin{array}{l}\text { Educational } \\
\text { Status }\end{array}$ & Ancestry & $\begin{array}{c}\text { Classification } \\
\text { of handedness }\end{array}$ & $\begin{array}{l}\text { Instrument of } \\
\text { handedness }\end{array}$ & $\begin{array}{c}\text { Length of } \\
\text { questionnaire } \\
\text { (number of items) }\end{array}$ & $\begin{array}{c}\text { Response } \\
\text { format }\end{array}$ & $\begin{array}{c}\text { Main } \\
\text { Purpose of } \\
\text { the study }\end{array}$ & Report & Sport elite \\
\hline $\begin{array}{l}\text { Aggleton, } \\
\text { Kentridge, \& } \\
\text { Good (1994) }\end{array}$ & 1,538 & $\begin{array}{c}\text { general } \\
\text { population }\end{array}$ & European & $\mathrm{R}-\mathrm{L}$ & Writing hand & 1 & $\mathrm{n} / \mathrm{a}$ & handedness & Self-report & no \\
\hline \multirow{2}{*}{$\begin{array}{l}\text { Aggleton \& } \\
\text { Wood (1990) }\end{array}$} & 344 & $\begin{array}{l}\text { general } \\
\text { population }\end{array}$ & \multirow{2}{*}{ European } & $\mathrm{R}-\mathrm{L}$ & $\begin{array}{l}\text { Observation of } \\
\text { an action/official } \\
\text { records }\end{array}$ & 1 & R-M-L & other & No self-report & yes \\
\hline & 363 & $\begin{array}{l}\text { College } \\
\text { students }\end{array}$ & & R-M-L & $\mathrm{n} / \mathrm{a}$ & 1 & R-M-L & other & Self-report & no \\
\hline $\begin{array}{l}\text { Anakwe, } \\
\text { Huntley, \& } \\
\text { McEachan } \\
(2007)\end{array}$ & 250 & $\begin{array}{c}\text { general } \\
\text { population }\end{array}$ & European & $\mathrm{R}-\mathrm{L}$ & $\begin{array}{c}\text { Self- } \\
\text { classification }\end{array}$ & 1 & $\mathrm{n} / \mathrm{a}$ & other & Self-report & no \\
\hline \multirow{2}{*}{ Annett (1973) } & 3,644 & $\begin{array}{l}\text { College } \\
\text { students }\end{array}$ & \multirow{2}{*}{ European } & R-L & Writing hand & 1 & $\mathrm{n} / \mathrm{a}$ & handedness & Self-report & no \\
\hline & 7,288 & $\begin{array}{c}\text { general } \\
\text { population }\end{array}$ & & R-L & Writing hand & 1 & $\mathrm{n} / \mathrm{a}$ & handedness & $\mathrm{n} / \mathrm{a}$ & no \\
\hline \multirow{2}{*}{ Annett (1979) } & 804 & $\begin{array}{l}\text { College } \\
\text { students }\end{array}$ & \multirow{2}{*}{ European } & R-L & Writing hand & 1 & R-L & handedness & Self-report & no \\
\hline & 690 & $\begin{array}{c}\text { general } \\
\text { population }\end{array}$ & & R-L & Writing hand & 1 & R-L & handedness & No self-report & no \\
\hline
\end{tabular}


HUMAN HANDEDNESS: A META-ANALYSIS

\begin{tabular}{|c|c|c|c|c|c|c|c|c|c|c|}
\hline & 1540 & $\begin{array}{c}\text { general } \\
\text { population }\end{array}$ & & R-L & Writing hand & 1 & R-L & handedness & No self-report & no \\
\hline \multirow{4}{*}{ Annett (1985) } & 642 & $\begin{array}{c}\text { general } \\
\text { population }\end{array}$ & $\mathrm{n} / \mathrm{a}$ & R-L & $\mathrm{n} / \mathrm{a}$ & $\mathrm{n} / \mathrm{a}$ & $\mathrm{n} / \mathrm{a}$ & handedness & Self-report & no \\
\hline & 747 & $\begin{array}{c}\text { general } \\
\text { population }\end{array}$ & $\mathrm{n} / \mathrm{a}$ & R-L & $\mathrm{n} / \mathrm{a}$ & $\mathrm{n} / \mathrm{a}$ & $\mathrm{n} / \mathrm{a}$ & handedness & Self-report & no \\
\hline & 224 & $\begin{array}{c}\text { general } \\
\text { population }\end{array}$ & $\mathrm{n} / \mathrm{a}$ & R-L & $\begin{array}{l}\text { Observation of } \\
\text { an action/official } \\
\text { records }\end{array}$ & 1 & $\mathrm{n} / \mathrm{a}$ & other & No self-report & yes \\
\hline & 66 & $\begin{array}{c}\text { general } \\
\text { population }\end{array}$ & $\mathrm{n} / \mathrm{a}$ & $\mathrm{R}-\mathrm{L}$ & $\begin{array}{l}\text { Observation of } \\
\text { an action/official } \\
\text { records }\end{array}$ & 1 & $\mathrm{n} / \mathrm{a}$ & other & No self-report & yes \\
\hline Annett (2002) & 200 & $\begin{array}{c}\text { general } \\
\text { population }\end{array}$ & $\mathrm{n} / \mathrm{a}$ & R-L & $\begin{array}{l}\text { Observation of } \\
\text { an action/official } \\
\text { records }\end{array}$ & 1 & $\mathrm{n} / \mathrm{a}$ & other & No self-report & yes \\
\hline \multirow{3}{*}{ Annett (2008) } & 578 & $\begin{array}{c}\text { general } \\
\text { population }\end{array}$ & \multirow{3}{*}{ European } & R-L & Writing hand & 1 & $\mathrm{n} / \mathrm{a}$ & handedness & Self-report & no \\
\hline & 1,670 & $\begin{array}{l}\text { College } \\
\text { students }\end{array}$ & & R-L & Writing hand & 1 & $\mathrm{n} / \mathrm{a}$ & handedness & Self-report & no \\
\hline & 3,364 & $\begin{array}{c}\text { general } \\
\text { population }\end{array}$ & & R-L & Writing hand & 1 & $\mathrm{n} / \mathrm{a}$ & handedness & No self-report & no \\
\hline $\begin{array}{l}\text { Annett \& } \\
\text { Kilshaw (1982) }\end{array}$ & 1,550 & $\begin{array}{l}\text { College } \\
\text { students }\end{array}$ & European & R-L & Writing hand & 1 & $\mathrm{n} / \mathrm{a}$ & other & Self-report & no \\
\hline $\begin{array}{l}\text { Ardila \& } \\
\text { Rosselli (2001) }\end{array}$ & 6,941 & $\begin{array}{c}\text { general } \\
\text { population }\end{array}$ & $\mathrm{n} / \mathrm{a}$ & R-M-L & $\begin{array}{c}\text { Self- } \\
\text { classification }\end{array}$ & 1 & R-M-L & handedness & Self-report & no \\
\hline \multirow[t]{2}{*}{$\begin{array}{l}\text { Arning et al. } \\
\text { (2015) }\end{array}$} & 1,056 & $\begin{array}{c}\text { general } \\
\text { population }\end{array}$ & European & R-M-L & EHI & 10 & R-L & handedness & Self-report & no \\
\hline & 2,027 & $\begin{array}{l}\text { general } \\
\text { population }\end{array}$ & European & R-L & Writing hand & 1 & R-L & handedness & Self-report & no \\
\hline
\end{tabular}


HUMAN HANDEDNESS: A META-ANALYSIS

\begin{tabular}{|c|c|c|c|c|c|c|c|c|c|c|}
\hline \multirow{2}{*}{ Ashton (1982) } & 840 & $\begin{array}{c}\text { general } \\
\text { population }\end{array}$ & East Asian & R-L & Writing hand & 1 & R-L & handedness & Self-report & no \\
\hline & 758 & $\begin{array}{c}\text { general } \\
\text { population }\end{array}$ & $\mathrm{n} / \mathrm{a}$ & $\mathrm{R}-\mathrm{L}$ & Writing hand & 1 & R-L & handedness & Self-report & no \\
\hline $\begin{array}{l}\text { Azémar \& Stein } \\
\text { (1994) }\end{array}$ & 2,490 & $\begin{array}{c}\text { general } \\
\text { population }\end{array}$ & $\mathrm{n} / \mathrm{a}$ & R-L & $\begin{array}{l}\text { Observation of } \\
\text { an action/official } \\
\text { records }\end{array}$ & 1 & $\mathrm{n} / \mathrm{a}$ & handedness & No self-report & yes \\
\hline $\begin{array}{l}\text { Bakan \& } \\
\text { Putnam (1974) }\end{array}$ & 400 & $\begin{array}{l}\text { College } \\
\text { students }\end{array}$ & European & R-L & Writing hand & 1 & $\mathrm{n} / \mathrm{a}$ & other & Self-report & no \\
\hline $\begin{array}{l}\text { Barut, Ozer, } \\
\text { Sevinc, Gumus, } \\
\text { \& Yunten } \\
(2007)\end{array}$ & 633 & $\mathrm{n} / \mathrm{a}$ & $\mathrm{n} / \mathrm{a}$ & R-M-L & EHI & 10 & $\begin{array}{c}+ \text { or }++ \\
\text { under R-L } \\
\text { columns }\end{array}$ & other & Self-report & no \\
\hline $\begin{array}{l}\text { Beckman \& } \\
\text { Elston (1962) }\end{array}$ & 981 & $\begin{array}{c}\text { general } \\
\text { population }\end{array}$ & European & R-L & $\mathrm{n} / \mathrm{a}$ & $\mathrm{n} / \mathrm{a}$ & $\mathrm{n} / \mathrm{a}$ & handedness & Self-report & no \\
\hline $\begin{array}{l}\text { Betancur, } \\
\text { Velez, } \\
\text { Cabanieu, } \\
\text { LeMoal, \& } \\
\text { Neveu (1990) }\end{array}$ & 205 & $\begin{array}{c}\text { general } \\
\text { population }\end{array}$ & European & R-M-L & $\mathrm{n} / \mathrm{a}$ & 10 & 5-point scale & other & Self-report & no \\
\hline Birkett (1981) & 125 & $\begin{array}{c}\text { general } \\
\text { population }\end{array}$ & European & R-L & EHI & 10 & $\mathrm{n} / \mathrm{a}$ & handedness & Self-report & no \\
\hline $\begin{array}{l}\text { Briggs \& Nebes } \\
(1975)\end{array}$ & 1,599 & $\begin{array}{l}\text { College } \\
\text { students }\end{array}$ & European & R-M-L & Briggs \& Nebes & 12 & 5-point scale & handedness & Self-report & no \\
\hline $\begin{array}{l}\text { Brito, Brito, } \\
\text { Paumgartten, \& } \\
\text { Lins (1989) }\end{array}$ & 959 & $\begin{array}{l}\text { College } \\
\text { students }\end{array}$ & $\mathrm{n} / \mathrm{a}$ & R-M-L & EHI & 10 & R-M-L & handedness & Self-report & no \\
\hline Bryden (1977) & 1,106 & $\begin{array}{l}\text { College } \\
\text { students }\end{array}$ & European & R-L & Writing hand & 1 & 5-point scale & handedness & Self-report & no \\
\hline Bryden (1989) & 794 & $\begin{array}{l}\text { College } \\
\text { students }\end{array}$ & European & R-L & $\mathrm{n} / \mathrm{a}$ & 8 & $\mathrm{n} / \mathrm{a}$ & other & Self-report & no \\
\hline
\end{tabular}


HUMAN HANDEDNESS: A META-ANALYSIS

\begin{tabular}{|c|c|c|c|c|c|c|c|c|c|c|}
\hline $\begin{array}{l}\text { Bryden \& Roy } \\
\text { (2005) }\end{array}$ & 153 & $\begin{array}{l}\text { College } \\
\text { students }\end{array}$ & European & $\mathrm{R}-\mathrm{L}$ & Writing hand & 1 & $\mathrm{n} / \mathrm{a}$ & other & Self-report & no \\
\hline $\begin{array}{l}\text { Buchtel \& } \\
\text { Rueckert (1984) }\end{array}$ & 740 & $\begin{array}{l}\text { College } \\
\text { students }\end{array}$ & European & $\mathrm{R}-\mathrm{L}$ & Writing hand & 1 & $\mathrm{R}-\mathrm{L}$ & other & Self-report & no \\
\hline $\begin{array}{l}\text { Cannon et al. } \\
\text { (1995) }\end{array}$ & 43 & $\begin{array}{c}\text { general } \\
\text { population }\end{array}$ & European & R-M-L & EHI & 10 & $\mathrm{n} / \mathrm{a}$ & handedness & Self-report & no \\
\hline $\begin{array}{l}\text { Carriere \& } \\
\text { Raymond } \\
\text { (2000) }\end{array}$ & 246 & $\begin{array}{c}\text { general } \\
\text { population }\end{array}$ & $\begin{array}{l}\text { sub- } \\
\text { Sahara } \\
\text { African }\end{array}$ & $\mathrm{R}-\mathrm{L}$ & $\begin{array}{l}\text { Observation of } \\
\text { an action/official } \\
\text { records }\end{array}$ & 1 & $\mathrm{R}-\mathrm{L}$ & other & No self-report & no \\
\hline $\begin{array}{l}\text { Casey \& } \\
\text { Brabeck (1989) }\end{array}$ & 433 & $\begin{array}{l}\text { College } \\
\text { students }\end{array}$ & European & R-nonR & EHI & 10 & $\begin{array}{c}+ \text { or }++ \\
\text { under R-L } \\
\text { columns }\end{array}$ & other & Self-report & no \\
\hline $\begin{array}{l}\text { Chamberlain } \\
\text { (1928) }\end{array}$ & 4,354 & $\begin{array}{c}\text { general } \\
\text { population }\end{array}$ & European & $\mathrm{R}-\mathrm{L}$ & Writing hand & 1 & R-L & handedness & No self-report & no \\
\hline $\begin{array}{l}\text { Chapman \& } \\
\text { Walsh (1973) }\end{array}$ & 923 & $\mathrm{n} / \mathrm{a}$ & European & R-M-L & $\begin{array}{l}\text { Observation of } \\
\text { an action/official } \\
\text { records }\end{array}$ & 1 & R-M-L & handedness & Self-report & no \\
\hline $\begin{array}{l}\text { Chapman \& } \\
\text { Chapman } \\
\text { (1987) }\end{array}$ & 5,825 & $\begin{array}{l}\text { College } \\
\text { students }\end{array}$ & European & R-M-L & $\mathrm{n} / \mathrm{a}$ & 13 & R-M-L & handedness & Self-report & no \\
\hline $\begin{array}{l}\text { Chen, Sachdev, } \\
\text { Wen, \& Anstey } \\
\text { (2007) }\end{array}$ & 411 & $\begin{array}{c}\text { general } \\
\text { population }\end{array}$ & European & $\mathrm{R}-\mathrm{L}$ & EHI & 10 & $\mathrm{n} / \mathrm{a}$ & other & Self-report & no \\
\hline Chisnall (2010) & 302 & $\begin{array}{c}\text { general } \\
\text { population }\end{array}$ & European & R-M-L & Writing hand & 1 & $\mathrm{n} / \mathrm{a}$ & handedness & Self-report & no \\
\hline $\begin{array}{l}\text { Çiçek, Arabacı, } \\
\text { \& Çanakçı } \\
(2010)\end{array}$ & 1,510 & $\begin{array}{c}\text { general } \\
\text { population }\end{array}$ & $\mathrm{n} / \mathrm{a}$ & $\mathrm{R}-\mathrm{L}$ & EHI & 10 & $\mathrm{n} / \mathrm{a}$ & handedness & Self-report & no \\
\hline
\end{tabular}


HUMAN HANDEDNESS: A META-ANALYSIS

\begin{tabular}{|c|c|c|c|c|c|c|c|c|c|c|}
\hline Coren (1989) & 1,896 & $\begin{array}{l}\text { College } \\
\text { students }\end{array}$ & European & $\mathrm{R}-\mathrm{L}$ & $\begin{array}{l}4 \text { items from } \\
\text { Porac \& Coren } \\
\text { Laterality } \\
\text { Inventory }\end{array}$ & 4 & $\mathrm{n} / \mathrm{a}$ & other & Self-report & no \\
\hline Coren (1993) & 3,307 & $\begin{array}{l}\text { College } \\
\text { students }\end{array}$ & European & $\mathrm{R}-\mathrm{L}$ & $\begin{array}{l}4 \text { items from } \\
\text { Porac \& Coren } \\
\text { Laterality } \\
\text { Inventory }\end{array}$ & 4 & R-M-L & handedness & Self-report & no \\
\hline Coren (1995) & 2,596 & $\begin{array}{c}\text { general } \\
\text { population }\end{array}$ & European & $\mathrm{R}-\mathrm{L}$ & $\begin{array}{l}4 \text { items from } \\
\text { Porac \& Coren } \\
\text { Laterality } \\
\text { Inventory }\end{array}$ & $\mathrm{n} / \mathrm{a}$ & R-M-L & other & No self-report & no \\
\hline $\begin{array}{l}\text { Coren \& Porac } \\
\text { (1979) }\end{array}$ & 1,758 & $\begin{array}{c}\text { general } \\
\text { population }\end{array}$ & European & $\mathrm{R}-\mathrm{L}$ & Writing hand & 1 & R-L & handedness & Self-report & no \\
\hline \multirow{2}{*}{$\begin{array}{l}\text { Coren \& Porac } \\
\text { (1980) }\end{array}$} & 2,761 & $\begin{array}{c}\text { general } \\
\text { population }\end{array}$ & \multirow{2}{*}{ European } & $\mathrm{R}-\mathrm{L}$ & $\begin{array}{l}4 \text { items from } \\
\text { Porac \& Coren } \\
\text { Laterality } \\
\text { Inventory }\end{array}$ & 4 & R-M-L & other & Self-report & no \\
\hline & 1,410 & $\begin{array}{l}\text { general } \\
\text { population }\end{array}$ & & $\mathrm{R}-\mathrm{L}$ & $\begin{array}{l}4 \text { items from } \\
\text { Porac \& Coren } \\
\text { Laterality } \\
\text { Inventory }\end{array}$ & 4 & R-M-L & other & Self-report & no \\
\hline $\begin{array}{l}\text { Coren, } \\
\text { Searleman, \& } \\
\text { Porac (1986) }\end{array}$ & 1,180 & $\begin{array}{l}\text { College } \\
\text { students }\end{array}$ & European & $\mathrm{R}-\mathrm{L}$ & $\begin{array}{l}4 \text { items from } \\
\text { Porac \& Coren } \\
\text { Laterality } \\
\text { Inventory }\end{array}$ & 4 & R-M-L & other & Self-report & no \\
\hline $\begin{array}{l}\text { Cornell \& } \\
\text { McManus } \\
\text { (1992) }\end{array}$ & 266 & $\begin{array}{l}\text { College } \\
\text { students }\end{array}$ & European & $\mathrm{R}-\mathrm{L}$ & Writing hand & 1 & $\mathrm{n} / \mathrm{a}$ & handedness & Self-report & no \\
\hline \multirow{2}{*}{$\begin{array}{l}\text { Cosenza \& } \\
\text { Mingoti (1993) }\end{array}$} & 1,961 & $\begin{array}{l}\text { College } \\
\text { students }\end{array}$ & \multirow[t]{2}{*}{$\mathrm{n} / \mathrm{a}$} & $\mathrm{R}-\mathrm{L}$ & EHI & 10 & $\begin{array}{c}+ \text { or }++ \\
\text { under R-L } \\
\text { columns }\end{array}$ & other & Self-report & no \\
\hline & 14,629 & $\begin{array}{c}\text { general } \\
\text { population }\end{array}$ & & R-L & EHI & 10 & $\begin{array}{c}+ \text { or }++ \\
\text { under R-L }\end{array}$ & other & Self-report & no \\
\hline
\end{tabular}


HUMAN HANDEDNESS: A META-ANALYSIS

columns

\begin{tabular}{|c|c|c|c|c|c|c|c|c|c|c|}
\hline $\begin{array}{l}\text { Cosenza \& } \\
\text { Mingoti (1995) }\end{array}$ & 15,389 & $\begin{array}{l}\text { general } \\
\text { population }\end{array}$ & $\mathrm{n} / \mathrm{a}$ & R-L & EHI & $\mathrm{n} / \mathrm{a}$ & $\mathrm{n} / \mathrm{a}$ & other & Self-report & no \\
\hline Cuff (1931) & 109 & $\begin{array}{l}\text { College } \\
\text { students }\end{array}$ & European & R-L & $\mathrm{n} / \mathrm{a}$ & 8 & R-L & handedness & Self-report & no \\
\hline $\begin{array}{l}\text { Curt, De } \\
\text { Agostini, } \\
\text { Maccario, \& } \\
\text { Dellatolas } \\
\text { (1995) }\end{array}$ & 1,609 & $\begin{array}{l}\text { general } \\
\text { population }\end{array}$ & European & R-L & $\mathrm{n} / \mathrm{a}$ & 12 & R-M-L & handedness & Self-report & no \\
\hline $\begin{array}{l}\text { Dane \& } \\
\text { Erzurumluoğlu } \\
\text { (2003) }\end{array}$ & 326 & $\begin{array}{c}\text { general } \\
\text { population }\end{array}$ & $\mathrm{n} / \mathrm{a}$ & R-L & EHI & 10 & R-M-L & other & Self-report & yes \\
\hline \multirow[t]{2}{*}{ Dane (2019) } & 107 & $\begin{array}{l}\text { College } \\
\text { students }\end{array}$ & $\begin{array}{l}\text { sub- } \\
\text { Sahara } \\
\text { African }\end{array}$ & R-L & EHI & 10 & $\mathrm{n} / \mathrm{a}$ & handedness & Self-report & no \\
\hline & 200 & $\begin{array}{l}\text { general } \\
\text { population }\end{array}$ & $\begin{array}{l}\text { sub- } \\
\text { Sahara } \\
\text { African }\end{array}$ & $\mathrm{R}-\mathrm{L}$ & EHI & 10 & $\mathrm{n} / \mathrm{a}$ & handedness & Self-report & no \\
\hline $\begin{array}{l}\text { Dane et al. } \\
(2009)\end{array}$ & 118 & $\begin{array}{c}\text { general } \\
\text { population }\end{array}$ & $\mathrm{n} / \mathrm{a}$ & R-M-L & EHI & 10 & $\mathrm{n} / \mathrm{a}$ & handedness & Self-report & no \\
\hline \multirow{5}{*}{$\begin{array}{l}\text { Dargent-Paré, } \\
\text { De Agostini, } \\
\text { Meshbah, } \\
\text { Mounir, \& } \\
\text { Dellatolas } \\
\text { (1992) }\end{array}$} & 652 & $\mathrm{n} / \mathrm{a}$ & $\mathrm{n} / \mathrm{a}$ & R-L & $\mathrm{n} / \mathrm{a}$ & 12 & R-M-L & other & Self-report & no \\
\hline & 685 & $\mathrm{n} / \mathrm{a}$ & European & R-L & $\mathrm{n} / \mathrm{a}$ & 12 & R-M-L & other & Self-report & no \\
\hline & 701 & $\mathrm{n} / \mathrm{a}$ & European & $\mathrm{R}-\mathrm{L}$ & $\mathrm{n} / \mathrm{a}$ & 12 & R-M-L & other & Self-report & no \\
\hline & 725 & $\mathrm{n} / \mathrm{a}$ & European & R-L & $\mathrm{n} / \mathrm{a}$ & 12 & R-M-L & other & Self-report & no \\
\hline & 2,301 & $\mathrm{n} / \mathrm{a}$ & European & R-L & $\mathrm{n} / \mathrm{a}$ & 12 & R-M-L & other & Self-report & no \\
\hline
\end{tabular}


HUMAN HANDEDNESS: A META-ANALYSIS

\begin{tabular}{|c|c|c|c|c|c|c|c|c|c|c|}
\hline \multirow{3}{*}{$\begin{array}{l}\text { De Agostini, } \\
\text { Khamis, Ahui, } \\
\text { \& Dellatolas } \\
\text { (1997) }\end{array}$} & 764 & $\begin{array}{c}\text { general } \\
\text { population }\end{array}$ & \multirow{3}{*}{$\begin{array}{l}\text { sub- } \\
\text { Sahara } \\
\text { African }\end{array}$} & $\mathrm{R}-\mathrm{L}$ & $\mathrm{n} / \mathrm{a}$ & 1 & R-M-L & handedness & No self-report & no \\
\hline & 755 & $\begin{array}{l}\text { College } \\
\text { students }\end{array}$ & & $\mathrm{R}-\mathrm{L}$ & $\mathrm{n} / \mathrm{a}$ & 10 & 5 -point scale & handedness & Self-report & no \\
\hline & 1,470 & $\begin{array}{c}\text { general } \\
\text { population }\end{array}$ & & $\mathrm{R}-\mathrm{L}$ & $\mathrm{n} / \mathrm{a}$ & 1 & R-M-L & handedness & No self-report & no \\
\hline $\begin{array}{l}\text { De Kovel, } \\
\text { Carrión- } \\
\text { Castillo, \& } \\
\text { Francks (2019) }\end{array}$ & 501,447 & $\begin{array}{c}\text { general } \\
\text { population }\end{array}$ & $\mathrm{n} / \mathrm{a}$ & R-M-L & $\begin{array}{c}\text { Self- } \\
\text { classification }\end{array}$ & 1 & R-M-L & handedness & Self-report & no \\
\hline \multirow{4}{*}{$\begin{array}{l}\text { De la Fuente, } \\
\text { Casasanto, } \\
\text { Román, \& } \\
\text { Santiago (2015) }\end{array}$} & 94 & $\begin{array}{l}\text { College } \\
\text { students }\end{array}$ & $\mathrm{n} / \mathrm{a}$ & $\mathrm{R}-\mathrm{L}$ & EHI & 10 & $\mathrm{n} / \mathrm{a}$ & handedness & Self-report & no \\
\hline & 71 & $\begin{array}{l}\text { College } \\
\text { students }\end{array}$ & European & $\mathrm{R}-\mathrm{L}$ & EHI & 10 & $\mathrm{n} / \mathrm{a}$ & handedness & Self-report & no \\
\hline & 29 & $\begin{array}{l}\text { College } \\
\text { students }\end{array}$ & European & $\mathrm{R}-\mathrm{L}$ & Writing hand & 1 & $\mathrm{n} / \mathrm{a}$ & handedness & Self-report & no \\
\hline & 40 & $\begin{array}{l}\text { College } \\
\text { students }\end{array}$ & $\mathrm{n} / \mathrm{a}$ & $\mathrm{R}-\mathrm{L}$ & $\mathrm{n} / \mathrm{a}$ & 4 & $\mathrm{n} / \mathrm{a}$ & handedness & Self-report & no \\
\hline $\begin{array}{l}\text { DeLisi et al. } \\
(2002)\end{array}$ & 288 & $\begin{array}{c}\text { general } \\
\text { population }\end{array}$ & European & R-M-L & Annett's & 25 & $\mathrm{n} / \mathrm{a}$ & handedness & Self-report & no \\
\hline $\begin{array}{l}\text { Demura et } \\
\text { al.(2006) }\end{array}$ & 3,557 & $\begin{array}{l}\text { general } \\
\text { population }\end{array}$ & East Asian & R-M-L & EHI & 10 & R-M-L & other & Self-report & no \\
\hline $\begin{array}{l}\text { Dinsdale, } \\
\text { Reddon, \& } \\
\text { Hurd (2011) }\end{array}$ & 395 & $\begin{array}{l}\text { College } \\
\text { students }\end{array}$ & European & R-M-L & Writing hand & 1 & $\begin{array}{c}+ \text { or }++ \\
\text { under R-L } \\
\text { columns }\end{array}$ & handedness & Self-report & no \\
\hline $\begin{array}{l}\text { Dirnberger } \\
(2012)\end{array}$ & 1,015 & $\begin{array}{l}\text { College } \\
\text { students }\end{array}$ & European & $\mathrm{R}-\mathrm{L}$ & EHI & 10 & 5 -point scale & handedness & Self-report & no \\
\hline Downey (1927) & 721 & $\mathrm{n} / \mathrm{a}$ & European & R-L & $\mathrm{n} / \mathrm{a}$ & 5 & $\mathrm{n} / \mathrm{a}$ & handedness & Self-report & no \\
\hline
\end{tabular}


HUMAN HANDEDNESS: A META-ANALYSIS

\begin{tabular}{|c|c|c|c|c|c|c|c|c|c|c|}
\hline $\begin{array}{l}\text { Dragovic, } \\
\text { Milenkovic, \& } \\
\text { Hammond } \\
\text { (2008) }\end{array}$ & 787 & $\begin{array}{c}\text { general } \\
\text { population }\end{array}$ & European & R-L & Writing hand & 1 & $\mathrm{n} / \mathrm{a}$ & handedness & Self-report & no \\
\hline \multirow{2}{*}{$\begin{array}{l}\text { Dronamraju } \\
\text { (1975) }\end{array}$} & 431 & $\begin{array}{c}\text { general } \\
\text { population }\end{array}$ & \multirow{2}{*}{$\mathrm{n} / \mathrm{a}$} & R-L & $\begin{array}{l}\text { Observation of } \\
\text { an action/official } \\
\text { records }\end{array}$ & 1 & R-L & handedness & No self-report & no \\
\hline & 86 & $\begin{array}{c}\text { general } \\
\text { population }\end{array}$ & & R-L & $\begin{array}{l}\text { Observation of } \\
\text { an action/official } \\
\text { records }\end{array}$ & 1 & R-L & handedness & No self-report & no \\
\hline $\begin{array}{l}\text { Elalmis \& Tan } \\
\text { (2005) }\end{array}$ & 22,461 & $\mathrm{n} / \mathrm{a}$ & $\mathrm{n} / \mathrm{a}$ & R-M-L & $\begin{array}{c}\text { Self- } \\
\text { classification }\end{array}$ & 1 & R-M-L & handedness & Self-report & no \\
\hline $\begin{array}{l}\text { Elalmis, \& Tan } \\
\text { (2008) }\end{array}$ & 197 & $\begin{array}{l}\text { College } \\
\text { students }\end{array}$ & $\mathrm{n} / \mathrm{a}$ & R-L & Writing hand & 1 & R-L & handedness & Self-report & no \\
\hline $\begin{array}{l}\text { Elias, Saucier, } \\
\text { \& Guylee } \\
\text { (2001) }\end{array}$ & 541 & $\begin{array}{l}\text { College } \\
\text { students }\end{array}$ & European & R-L & $\begin{array}{c}\text { Self- } \\
\text { classification }\end{array}$ & 1 & $\mathrm{n} / \mathrm{a}$ & other & Self-report & no \\
\hline $\begin{array}{l}\text { Ellis, Ellis, \& } \\
\text { Marshall (1988) }\end{array}$ & 6,577 & $\begin{array}{c}\text { general } \\
\text { population }\end{array}$ & European & R-L & EHI & 10 & $\begin{array}{c}+ \text { or }++ \\
\text { under R-L } \\
\text { columns }\end{array}$ & handedness & Self-report & no \\
\hline $\begin{array}{l}\text { Elneel, Carter, } \\
\text { Tang, \& } \\
\text { Cuschieri } \\
(2008)\end{array}$ & 52 & $\begin{array}{l}\text { College } \\
\text { students }\end{array}$ & European & R-M-L & $\mathrm{n} / \mathrm{a}$ & 7 & R-M-L & handedness & Self-report & no \\
\hline $\begin{array}{l}\text { Espírito-Santo } \\
\text { et al. (2017) }\end{array}$ & 342 & $\begin{array}{c}\text { general } \\
\text { population }\end{array}$ & European & R-M-L & EHI & 10 & $\begin{array}{c}+ \text { or }++ \\
\text { under R-L } \\
\text { columns }\end{array}$ & handedness & Self-report & no \\
\hline $\begin{array}{l}\text { Fagard, } \\
\text { Chapelain, \& } \\
\text { Bonnet (2015) }\end{array}$ & 704 & $\begin{array}{l}\text { general } \\
\text { population }\end{array}$ & European & R-M-L & $\mathrm{n} / \mathrm{a}$ & 15 & R-M-L & handedness & Self-report & no \\
\hline Faurie et al. & 11,895 & $\begin{array}{l}\text { general } \\
\text { population }\end{array}$ & European & R-L & $\begin{array}{c}\text { Self- } \\
\text { classification }\end{array}$ & 1 & R-L & handedness & Self-report & no \\
\hline & 13,954 & general & European & & $\mathrm{n} / \mathrm{a}$ & 6 & $\mathrm{n} / \mathrm{a}$ & other & & no \\
\hline
\end{tabular}


HUMAN HANDEDNESS: A META-ANALYSIS

\begin{tabular}{|c|c|c|c|c|c|c|c|c|c|c|}
\hline & & population & & $\mathrm{R}-\mathrm{L}$ & & & & & Self-report & \\
\hline \multirow{2}{*}{ Fry (1990) } & 366 & $\begin{array}{l}\text { College } \\
\text { students }\end{array}$ & \multirow{2}{*}{ European } & R-L & EHI & 10 & $\mathrm{n} / \mathrm{a}$ & other & No self-report & no \\
\hline & 721 & $\begin{array}{l}\text { general } \\
\text { population }\end{array}$ & & $\mathrm{R}-\mathrm{L}$ & Writing hand & 1 & $\mathrm{n} / \mathrm{a}$ & other & No self-report & no \\
\hline $\begin{array}{l}\text { Genetta-Wadley } \\
\& \text { Swirsky- } \\
\text { Sacchetti (1990) }\end{array}$ & 60 & $\begin{array}{l}\text { College } \\
\text { students }\end{array}$ & European & $\mathrm{R}-\mathrm{L}$ & Annett's & 12 & $\mathrm{n} / \mathrm{a}$ & other & Self-report & no \\
\hline $\begin{array}{l}\text { Gilbert \& } \\
\text { Wysocki (1992) }\end{array}$ & $1,177,507$ & $\begin{array}{c}\text { general } \\
\text { population }\end{array}$ & European & R-nonR & $\mathrm{n} / \mathrm{a}$ & 2 & $\mathrm{R}-\mathrm{L}$ & handedness & Self-report & no \\
\hline $\begin{array}{l}\text { Gladue \& } \\
\text { Bailey (1995) }\end{array}$ & 149 & $\begin{array}{c}\text { general } \\
\text { population }\end{array}$ & European & R-nonR & Annett's & 10 & 5-point scale & other & Self-report & no \\
\hline \multirow[t]{2}{*}{$\begin{array}{l}\text { Götestam } \\
\text { (1990) }\end{array}$} & 60 & $\begin{array}{l}\text { College } \\
\text { students }\end{array}$ & \multirow[b]{2}{*}{ European } & R-M-L & Writing hand & 1 & R-M-L & handedness & Self-report & no \\
\hline & 175 & $\begin{array}{l}\text { College } \\
\text { students }\end{array}$ & & R-M-L & Writing hand & 1 & R-M-L & handedness & Self-report & no \\
\hline $\begin{array}{l}\text { Green \& Young } \\
\text { (2001) }\end{array}$ & 284 & $\begin{array}{l}\text { College } \\
\text { students }\end{array}$ & European & R-M-L & $\mathrm{n} / \mathrm{a}$ & 6 & R-M-L & handedness & Self-report & no \\
\hline \multirow{2}{*}{$\begin{array}{l}\text { Grouios, } \\
\text { Tsorbatzoudis, } \\
\text { Alexandris \& } \\
\text { Barkoukis } \\
(2000)\end{array}$} & 1,112 & $\begin{array}{c}\text { general } \\
\text { population }\end{array}$ & European & $\mathrm{R}-\mathrm{L}$ & Briggs \& Nebes & 12 & 5-point scale & other & Self-report & yes \\
\hline & 1,187 & $\begin{array}{l}\text { College } \\
\text { students }\end{array}$ & European & $\mathrm{R}-\mathrm{L}$ & Briggs \& Nebes & 12 & 5-point scale & other & Self-report & no \\
\hline $\begin{array}{l}\text { Gunstad, } \\
\text { Spitznagel, } \\
\text { Luyster, Cohen, } \\
\text { \& Paul (2007) }\end{array}$ & 643 & $\begin{array}{c}\text { general } \\
\text { population }\end{array}$ & $\mathrm{n} / \mathrm{a}$ & R-nonR & EHI & 10 & $\mathrm{n} / \mathrm{a}$ & other & Self-report & no \\
\hline $\begin{array}{l}\text { Gupta, Sanyal, } \\
\& \text { Babbar }\end{array}$ & 84 & $\begin{array}{l}\text { College } \\
\text { students }\end{array}$ & $\mathrm{n} / \mathrm{a}$ & R-L & $\begin{array}{c}\text { Self- } \\
\text { classification }\end{array}$ & 1 & $\mathrm{n} / \mathrm{a}$ & handedness & Self-report & no \\
\hline
\end{tabular}


HUMAN HANDEDNESS: A META-ANALYSIS

\begin{tabular}{|c|c|c|c|c|c|c|c|c|c|c|}
\hline \multicolumn{11}{|l|}{ (2008) } \\
\hline $\begin{array}{l}\text { Gur \& Gur } \\
\text { (1977) }\end{array}$ & 200 & $\begin{array}{c}\text { general } \\
\text { population }\end{array}$ & European & R-L & $\mathrm{n} / \mathrm{a}$ & 23 & R-L & other & Self-report & no \\
\hline $\begin{array}{l}\text { Halpern, } \\
\text { Haviland, \& } \\
\text { Killian (1998) }\end{array}$ & 152,653 & $\begin{array}{c}\text { general } \\
\text { population }\end{array}$ & European & R-L & Writing hand & 1 & $\mathrm{R}-\mathrm{L}$ & other & Self-report & no \\
\hline $\begin{array}{l}\text { Hannay, } \\
\text { Ciaccia, Kerr, \& } \\
\text { Barrett (1990) }\end{array}$ & 1,185 & $\begin{array}{l}\text { College } \\
\text { students }\end{array}$ & European & R-M-L & $\mathrm{n} / \mathrm{a}$ & 10 & $\mathrm{n} / \mathrm{a}$ & other & Self-report & no \\
\hline $\begin{array}{l}\text { Hannula, } \\
\text { Bloigu, } \\
\text { Majamaa, Sorri, } \\
\& \text { Mäki-Torkko } \\
\text { (2012) }\end{array}$ & 850 & $\begin{array}{c}\text { general } \\
\text { population }\end{array}$ & European & R-L & $\begin{array}{c}\text { Self- } \\
\text { classification }\end{array}$ & 1 & $\mathrm{R}-\mathrm{L}$ & other & Self-report & no \\
\hline \multirow{2}{*}{$\begin{array}{l}\text { Harburg, } \\
\text { Feldstein, \& } \\
\text { Papsdorf (1978) }\end{array}$} & 735 & $\begin{array}{c}\text { general } \\
\text { population }\end{array}$ & European & $\mathrm{R}-\mathrm{L}$ & $\begin{array}{c}\text { Self- } \\
\text { classification }\end{array}$ & 1 & $\mathrm{R}-\mathrm{L}$ & other & Self-report & no \\
\hline & 761 & $\begin{array}{c}\text { general } \\
\text { population }\end{array}$ & $\begin{array}{l}\text { sub- } \\
\text { Sahara } \\
\text { African }\end{array}$ & R-L & $\begin{array}{c}\text { Self- } \\
\text { classification }\end{array}$ & 1 & R-L & other & Self-report & no \\
\hline \multirow{2}{*}{$\begin{array}{l}\text { Harburg, } \\
\text { Roeper, } \\
\text { Ozgoren, \& } \\
\text { Feldstein (1981) }\end{array}$} & 651 & $\begin{array}{c}\text { general } \\
\text { population }\end{array}$ & \multirow{2}{*}{ European } & R-L & Writing hand & 1 & $\mathrm{R}-\mathrm{L}$ & other & Self-report & no \\
\hline & 502 & $\begin{array}{c}\text { general } \\
\text { population }\end{array}$ & & R-L & Writing hand & 1 & R-L & other & Self-report & no \\
\hline $\begin{array}{l}\text { Harris \& } \\
\text { Gitterman } \\
(1978)\end{array}$ & 356 & $\begin{array}{l}\text { College } \\
\text { students }\end{array}$ & European & R-L & Briggs \& Nebes & 12 & 5-point scale & other & Self-report & no \\
\hline Harvey (1988) & 398 & $\begin{array}{l}\text { College } \\
\text { students }\end{array}$ & European & R-L & EHI & 10 & R-M-L & other & Self-report & no \\
\hline $\begin{array}{l}\text { Hatta \& } \\
\text { Kawakami } \\
\text { (1995) }\end{array}$ & 1,700 & $\begin{array}{l}\text { College } \\
\text { students }\end{array}$ & East Asian & R-M-L & $\mathrm{n} / \mathrm{a}$ & 10 & $\mathrm{n} / \mathrm{a}$ & handedness & Self-report & no \\
\hline Hatta \& & 1,199 & general & East Asian & R-L & $\mathrm{n} / \mathrm{a}$ & 10 & R-M-L & handedness & Self-report & no \\
\hline
\end{tabular}


HUMAN HANDEDNESS: A META-ANALYSIS

\begin{tabular}{|c|c|c|c|c|c|c|c|c|c|c|}
\hline $\begin{array}{l}\text { Nakatsuka } \\
\text { (1976) }\end{array}$ & & population & & & & & & & & \\
\hline \multirow{2}{*}{$\begin{array}{l}\text { Heim \& Watts } \\
\text { (1976) }\end{array}$} & 398 & $\begin{array}{l}\text { College } \\
\text { students }\end{array}$ & \multirow{2}{*}{ European } & R-L & Writing hand & 1 & R-L & other & Self-report & no \\
\hline & 492 & $\begin{array}{l}\text { College } \\
\text { students }\end{array}$ & & R-L & Writing hand & 1 & $\mathrm{R}-\mathrm{L}$ & other & Self-report & no \\
\hline $\begin{array}{l}\text { Heikkilä et al. } \\
\text { (2015) }\end{array}$ & 1,791 & $\begin{array}{c}\text { general } \\
\text { population }\end{array}$ & European & R-L & Writing hand & 1 & $\mathrm{R}-\mathrm{L}$ & handedness & Self-report & no \\
\hline $\begin{array}{l}\text { Hicks, Dusek, } \\
\text { Larsen, \& } \\
\text { Pellegrini } \\
(1980)\end{array}$ & 580 & $\begin{array}{l}\text { College } \\
\text { students }\end{array}$ & European & R-L & Briggs \& Nebes & 12 & $\mathrm{n} / \mathrm{a}$ & other & Self-report & no \\
\hline $\begin{array}{l}\text { Hicks \& } \\
\text { Kinsbourne } \\
\text { (1976) }\end{array}$ & 2,202 & $\begin{array}{c}\text { general } \\
\text { population }\end{array}$ & European & R-L & Writing hand & 1 & $\mathrm{R}-\mathrm{L}$ & handedness & No self-report & no \\
\hline $\begin{array}{l}\text { Hicks, } \\
\text { Pellegrini, \& } \\
\text { Evans (1978) }\end{array}$ & 728 & $\begin{array}{l}\text { College } \\
\text { students }\end{array}$ & European & R-L & Briggs \& Nebes & 12 & 5-point scale & other & Self-report & no \\
\hline Holder (1992) & 314 & $\begin{array}{l}\text { College } \\
\text { students }\end{array}$ & European & R-M-L & $\begin{array}{c}\text { Self- } \\
\text { classification }\end{array}$ & 1 & R-M-L & handedness & Self-report & no \\
\hline Holtzen (1994) & 260 & $\begin{array}{c}\text { general } \\
\text { population }\end{array}$ & European & R-M-L & $\mathrm{n} / \mathrm{a}$ & 5 & 5 -point scale & other & Self-report & no \\
\hline Holtzen (2000) & 1,685 & $\begin{array}{c}\text { general } \\
\text { population }\end{array}$ & $\mathrm{n} / \mathrm{a}$ & R-L & $\begin{array}{l}\text { Observation of } \\
\text { an action/official } \\
\text { records }\end{array}$ & 1 & $\mathrm{R}-\mathrm{L}$ & other & No self-report & yes \\
\hline $\begin{array}{l}\text { Hoogmartens \& } \\
\text { Caubergh } \\
\text { (1987) }\end{array}$ & 128 & $\mathrm{n} / \mathrm{a}$ & European & R-L & $\begin{array}{l}4 \text { items from } \\
\text { Porac \& Coren } \\
\text { Laterality } \\
\text { Inventory }\end{array}$ & 4 & R-M-L & other & Self-report & no \\
\hline Hoosain (1990) & 556 & $\begin{array}{l}\text { College } \\
\text { students }\end{array}$ & East Asian & R-M-L & $\mathrm{n} / \mathrm{a}$ & 10 & R-M-L & handedness & Self-report & no \\
\hline Huang \& Sejdić & 20 & general & European & R-M-L & EHI & 10 & $\mathrm{n} / \mathrm{a}$ & other & Self-report & no \\
\hline
\end{tabular}


HUMAN HANDEDNESS: A META-ANALYSIS

\begin{tabular}{|c|c|c|c|c|c|c|c|c|c|c|}
\hline (2013) & & population & & & & & & & & \\
\hline \multirow[t]{2}{*}{$\begin{array}{l}\text { Ida \& Bryden } \\
\text { (1996) }\end{array}$} & 655 & $\begin{array}{l}\text { College } \\
\text { students }\end{array}$ & East Asian & R-L & Writing hand & 1 & 5-point scale & handedness & Self-report & no \\
\hline & 620 & $\begin{array}{l}\text { College } \\
\text { students }\end{array}$ & European & R-L & Writing hand & 1 & 5-point scale & handedness & Self-report & no \\
\hline $\begin{array}{l}\text { Inglis \& } \\
\text { Lawson (1984) }\end{array}$ & 1,880 & $\begin{array}{l}\text { general } \\
\text { population }\end{array}$ & European & R-L & $\mathrm{n} / \mathrm{a}$ & 3 & $\mathrm{n} / \mathrm{a}$ & other & Self-report & no \\
\hline $\begin{array}{l}\text { Iwasaki, Kaiho, } \\
\text { \& Iseki (1995) }\end{array}$ & 1,755 & $\begin{array}{l}\text { general } \\
\text { population }\end{array}$ & East Asian & R-L & Writing hand & 15 & R-M-L & handedness & Self-report & no \\
\hline $\begin{array}{l}\text { Jung \& Jung } \\
\text { (2009) }\end{array}$ & 1,885 & $\begin{array}{l}\text { general } \\
\text { population }\end{array}$ & East Asian & R-M-L & $\mathrm{n} / \mathrm{a}$ & 13 & $\mathrm{n} / \mathrm{a}$ & handedness & Self-report & no \\
\hline $\begin{array}{l}\text { Kalaycıŏlu, } \\
\text { Kara, } \\
\text { Atbaşoğlu, \& } \\
\text { Nalçacı (2008) }\end{array}$ & 49 & $\begin{array}{l}\text { College } \\
\text { students }\end{array}$ & $\mathrm{n} / \mathrm{a}$ & R-nonR & $\mathrm{n} / \mathrm{a}$ & 13 & R-M-L & handedness & Self-report & no \\
\hline \multirow[t]{3}{*}{$\begin{array}{l}\text { Kalichman, } \\
\text { Korostishevsky, } \\
\text { \& Kobyliansky } \\
(2015)\end{array}$} & 1,187 & $\begin{array}{c}\text { general } \\
\text { population }\end{array}$ & European & R-L & Writing hand & 1 & $\mathrm{n} / \mathrm{a}$ & handedness & Self-report & no \\
\hline & 40 & $\begin{array}{l}\text { general } \\
\text { population }\end{array}$ & & R-L & $\begin{array}{c}\text { Self- } \\
\text { classification }\end{array}$ & 1 & $\mathrm{n} / \mathrm{a}$ & handedness & Self-report & no \\
\hline & 40 & $\begin{array}{l}\text { general } \\
\text { population }\end{array}$ & & R-L & $\begin{array}{c}\text { Self- } \\
\text { classification }\end{array}$ & 1 & $\mathrm{n} / \mathrm{a}$ & handedness & Self-report & no \\
\hline \multirow[t]{3}{*}{$\begin{array}{l}\text { Kauranen \& } \\
\text { Vanharanta } \\
\text { (1996) }\end{array}$} & 40 & $\begin{array}{c}\text { general } \\
\text { population }\end{array}$ & European & R-L & $\begin{array}{c}\text { Self- } \\
\text { classification }\end{array}$ & 1 & $\mathrm{n} / \mathrm{a}$ & handedness & Self-report & no \\
\hline & 40 & $\begin{array}{c}\text { general } \\
\text { population }\end{array}$ & & R-L & $\begin{array}{c}\text { Self- } \\
\text { classification }\end{array}$ & 1 & $\mathrm{n} / \mathrm{a}$ & handedness & Self-report & no \\
\hline & 40 & $\begin{array}{c}\text { general } \\
\text { population }\end{array}$ & & R-L & $\begin{array}{c}\text { Self- } \\
\text { classification }\end{array}$ & 1 & $\mathrm{n} / \mathrm{a}$ & handedness & Self-report & no \\
\hline $\begin{array}{l}\text { Klum et al. } \\
(2012)\end{array}$ & 750 & $\begin{array}{c}\text { general } \\
\text { population }\end{array}$ & European & R-L & $\begin{array}{c}\text { Self- } \\
\text { classification }\end{array}$ & 1 & $\mathrm{n} / \mathrm{a}$ & handedness & Self-report & no \\
\hline
\end{tabular}


HUMAN HANDEDNESS: A META-ANALYSIS

\begin{tabular}{|c|c|c|c|c|c|c|c|c|c|c|}
\hline $\begin{array}{l}\text { Kuderer \& } \\
\text { Kirchengast } \\
\text { (2016) }\end{array}$ & 55 & $\begin{array}{l}\text { College } \\
\text { students }\end{array}$ & European & R-M-L & $\begin{array}{l}\text { Observation of } \\
\text { an action/official } \\
\text { records }\end{array}$ & 22 & R-L & handedness & No self-report & no \\
\hline $\begin{array}{l}\text { Lai, Serra, } \\
\text { Petretto, } \\
\text { Masala, \& Preti } \\
\text { (2014) }\end{array}$ & 1,023 & $\begin{array}{l}\text { general } \\
\text { population }\end{array}$ & European & R-M-L & Writing hand & 1 & R-M-L & handedness & Self-report & no \\
\hline $\begin{array}{l}\text { Lambert \& } \\
\text { Hallett (2009) }\end{array}$ & 886 & $\begin{array}{c}\text { general } \\
\text { population }\end{array}$ & European & R-M-L & Writing hand & 1 & R-M-L & handedness & Self-report & no \\
\hline \multirow{4}{*}{$\begin{array}{l}\text { Lansky, } \\
\text { Feinstein, \& } \\
\text { Peterson (1988) }\end{array}$} & 888 & $\begin{array}{l}\text { general } \\
\text { population }\end{array}$ & European & R-L & Writing hand & 1 & R-M-L & handedness & Self-report & no \\
\hline & 853 & $\begin{array}{c}\text { general } \\
\text { population }\end{array}$ & European & R-L & Writing hand & 1 & R-M-L & handedness & Self-report & no \\
\hline & 185 & $\begin{array}{c}\text { general } \\
\text { population }\end{array}$ & $\begin{array}{c}\text { sub- } \\
\text { Sahara } \\
\text { African }\end{array}$ & R-L & Writing hand & 1 & R-M-L & handedness & Self-report & no \\
\hline & 157 & $\begin{array}{c}\text { general } \\
\text { population }\end{array}$ & $\begin{array}{c}\text { sub- } \\
\text { Sahara } \\
\text { African }\end{array}$ & R-L & Writing hand & 1 & R-M-L & handedness & Self-report & no \\
\hline $\begin{array}{l}\text { Lee-Feldstein, } \\
\& \text { Harburg } \\
\text { (1982) }\end{array}$ & 1,153 & $\begin{array}{c}\text { general } \\
\text { population }\end{array}$ & European & R-L & Writing hand & 1 & R-L & other & Self-report & no \\
\hline \multirow{2}{*}{$\begin{array}{l}\text { Leiber \& } \\
\text { Axelrod (1981) }\end{array}$} & 1,766 & $\begin{array}{l}\text { College } \\
\text { students }\end{array}$ & \multirow{2}{*}{ European } & R-M-L & $\begin{array}{c}\text { Self- } \\
\text { classification }\end{array}$ & 1 & R-M-L & handedness & Self-report & no \\
\hline & 711 & $\begin{array}{l}\text { College } \\
\text { students }\end{array}$ & & R-M-L & $\begin{array}{c}\text { Self- } \\
\text { classification }\end{array}$ & 1 & R-M-L & handedness & Self-report & no \\
\hline $\begin{array}{l}\text { Lester, } \\
\text { Werlinen, \& } \\
\text { Heinle (1982) }\end{array}$ & 2,168 & $\mathrm{n} / \mathrm{a}$ & European & $\mathrm{R}-\mathrm{L}$ & $\mathrm{n} / \mathrm{a}$ & $\mathrm{n} / \mathrm{a}$ & $\mathrm{n} / \mathrm{a}$ & other & Self-report & no \\
\hline $\begin{array}{l}\text { Levander \& } \\
\text { Schalling }\end{array}$ & 921 & College & European & R-M-L & Writing hand & 1 & 5 -point scale & handedness & Self-report & no \\
\hline
\end{tabular}


HUMAN HANDEDNESS: A META-ANALYSIS

\begin{tabular}{|c|c|c|c|c|c|c|c|c|c|c|}
\hline (1988) & & students & & & & & & & & \\
\hline \multirow[t]{2}{*}{$\begin{array}{l}\text { Lien, Chen, } \\
\text { Hsiao, \& } \\
\text { Tsuang (2015) }\end{array}$} & 626 & $\begin{array}{l}\text { College } \\
\text { students }\end{array}$ & East Asian & R-L & Writing hand & 1 & 5-point scale & handedness & Self-report & no \\
\hline & 1,314 & $\begin{array}{c}\text { general } \\
\text { population }\end{array}$ & East Asian & R-L & Writing hand & 1 & 5-point scale & handedness & Self-report & no \\
\hline Lippa (2003) & 1,056 & $\mathrm{n} / \mathrm{a}$ & European & R-M-L & $\mathrm{n} / \mathrm{a}$ & 1 & 5-point scale & other & Self-report & no \\
\hline $\begin{array}{l}\text { Loffing, Sölter, } \\
\text { \& Hagemann } \\
(2014)\end{array}$ & 903 & $\begin{array}{l}\text { College } \\
\text { students }\end{array}$ & European & R-L & EHI & 10 & 5-point scale & handedness & Self-report & no \\
\hline Loffing (2017) & 1,485 & $\begin{array}{c}\text { general } \\
\text { population }\end{array}$ & $\mathrm{n} / \mathrm{a}$ & $\mathrm{R}-\mathrm{L}$ & $\begin{array}{l}\text { Observation of } \\
\text { an action/official } \\
\text { records }\end{array}$ & 1 & $\mathrm{n} / \mathrm{a}$ & handedness & No self-report & yes \\
\hline $\begin{array}{l}\text { Lui, Baker, } \\
\text { Nfila, Perera, \& } \\
\text { Stephens (2012) }\end{array}$ & 62 & $\begin{array}{l}\text { College } \\
\text { students }\end{array}$ & European & R-L & $\mathrm{n} / \mathrm{a}$ & $\mathrm{n} / \mathrm{a}$ & 5-point scale & handedness & Self-report & no \\
\hline $\begin{array}{l}\text { Lyle, } \\
\text { Chapman, \& } \\
\text { Hatton (2013) }\end{array}$ & 163 & $\begin{array}{l}\text { College } \\
\text { students }\end{array}$ & European & R-L & EHI & 10 & 5-point scale & handedness & Self-report & no \\
\hline $\begin{array}{l}\text { Maehara et al. } \\
\text { (1988) }\end{array}$ & 2,459 & $\mathrm{n} / \mathrm{a}$ & East Asian & R-nonR & EHI & 10 & R-M-L & handedness & Self-report & no \\
\hline $\begin{array}{l}\text { Marchant- } \\
\text { Haycox, } \\
\text { McManus, \& } \\
\text { Wilson (1991) }\end{array}$ & 396 & $\begin{array}{c}\text { general } \\
\text { population }\end{array}$ & European & R-L & $\mathrm{n} / \mathrm{a}$ & $\mathrm{n} / \mathrm{a}$ & 5-point scale & other & Self-report & no \\
\hline $\begin{array}{l}\text { Marmolejo- } \\
\text { Ramos et al. } \\
\text { (2017) }\end{array}$ & 1160 & $\begin{array}{l}\text { College } \\
\text { students }\end{array}$ & $\mathrm{n} / \mathrm{a}$ & R-L & $\begin{array}{c}\text { Self- } \\
\text { classification }\end{array}$ & 1 & $\mathrm{n} / \mathrm{a}$ & other & Self-report & no \\
\hline
\end{tabular}


HUMAN HANDEDNESS: A META-ANALYSIS

\begin{tabular}{|c|c|c|c|c|c|c|c|c|c|c|}
\hline $\begin{array}{l}\text { Martin \& Porac } \\
(2007)\end{array}$ & 1,635 & $\begin{array}{c}\text { general } \\
\text { population }\end{array}$ & $\mathrm{n} / \mathrm{a}$ & R-L & $\begin{array}{c}\text { Self- } \\
\text { classification }\end{array}$ & 1 & 5-point scale & handedness & Self-report & no \\
\hline $\begin{array}{l}\text { Mascie-Taylor, } \\
\text { MacLarnon, } \\
\text { Lanigan, \& } \\
\text { McManus } \\
\text { (1981) }\end{array}$ & 141 & $\begin{array}{c}\text { general } \\
\text { population }\end{array}$ & European & R-L & Writing hand & 1 & $\mathrm{R}-\mathrm{L}$ & other & Self-report & no \\
\hline $\begin{array}{l}\text { Mascie-Taylor } \\
(1980)\end{array}$ & 386 & $\begin{array}{c}\text { general } \\
\text { population }\end{array}$ & European & R-L & Writing hand & 1 & $\mathrm{R}-\mathrm{L}$ & other & Self-report & no \\
\hline $\begin{array}{l}\text { McFarland \& } \\
\text { Anderson } \\
\text { (1980) }\end{array}$ & 181 & $\begin{array}{l}\text { College } \\
\text { students }\end{array}$ & European & R-L & Writing hand & 1 & 5-point scale & handedness & Self-report & no \\
\hline McGee (1976) & 112 & $\begin{array}{l}\text { College } \\
\text { students }\end{array}$ & European & R-L & $\mathrm{n} / \mathrm{a}$ & 7 & $\mathrm{n} / \mathrm{a}$ & other & Self-report & no \\
\hline $\begin{array}{l}\text { McGee \& } \\
\text { Cozad (1980) }\end{array}$ & 1,230 & $\begin{array}{l}\text { College } \\
\text { students }\end{array}$ & European & R-nonR & EHI & 10 & $\mathrm{n} / \mathrm{a}$ & handedness & Self-report & no \\
\hline $\begin{array}{l}\text { McKeever \& } \\
\text { Rich (1990) }\end{array}$ & 3,080 & $\begin{array}{l}\text { College } \\
\text { students }\end{array}$ & European & R-L & Writing hand & 10 & $\mathrm{n} / \mathrm{a}$ & other & Self-report & no \\
\hline $\begin{array}{l}\text { McManus } \\
\text { (1986) }\end{array}$ & 2,028 & $\begin{array}{c}\text { general } \\
\text { population }\end{array}$ & European & R-L & $\begin{array}{c}\text { Self- } \\
\text { classification }\end{array}$ & 1 & $\mathrm{R}-\mathrm{L}$ & $\mathrm{n} / \mathrm{a}$ & Self-report & no \\
\hline \multirow[b]{2}{*}{ Merrell (1957) } & 123 & $\begin{array}{c}\text { general } \\
\text { population }\end{array}$ & \multirow{2}{*}{ European } & R-L & Writing hand & 1 & $\mathrm{n} / \mathrm{a}$ & handedness & Self-report & no \\
\hline & 497 & $\begin{array}{c}\text { general } \\
\text { population }\end{array}$ & & R-L & Writing hand & 1 & $\mathrm{n} / \mathrm{a}$ & handedness & No self-report & no \\
\hline $\begin{array}{l}\text { Mészáros et al. } \\
\text { (2006) }\end{array}$ & 150 & $\begin{array}{c}\text { general } \\
\text { population }\end{array}$ & European & R-L & $\mathrm{n} / \mathrm{a}$ & $\mathrm{n} / \mathrm{a}$ & $\mathrm{n} / \mathrm{a}$ & other & Self-report & no \\
\hline $\begin{array}{l}\text { Milenković, } \\
\text { Brkić, \& } \\
\text { Belojević }\end{array}$ & 1,202 & $\begin{array}{c}\text { general } \\
\text { population }\end{array}$ & European & R-L & Writing hand & 1 & $\mathrm{n} / \mathrm{a}$ & handedness & Self-report & no \\
\hline
\end{tabular}


HUMAN HANDEDNESS: A META-ANALYSIS

\begin{tabular}{|c|c|c|c|c|c|c|c|c|c|c|}
\hline \multicolumn{11}{|l|}{ (2013) } \\
\hline $\begin{array}{l}\text { Morley \& } \\
\text { Caffrey (1994) }\end{array}$ & 3,814 & $\begin{array}{c}\text { general } \\
\text { population }\end{array}$ & European & R-M-L & Writing hand & 1 & R-M-L & other & Self-report & no \\
\hline $\begin{array}{l}\text { Mustanski, } \\
\text { Bailey, \& } \\
\text { Kaspar (2002) }\end{array}$ & 382 & $\begin{array}{l}\text { College } \\
\text { students }\end{array}$ & European & R-M-L & $\begin{array}{c}\text { Self- } \\
\text { classification }\end{array}$ & 1 & R-M-L & other & Self-report & no \\
\hline $\begin{array}{l}\text { Nalçaci, } \\
\text { Kalaycioğlu, } \\
\text { Çiçek, \& Genç } \\
\text { (2001) }\end{array}$ & 310 & $\begin{array}{l}\text { College } \\
\text { students }\end{array}$ & $\mathrm{n} / \mathrm{a}$ & R-nonR & $\mathrm{n} / \mathrm{a}$ & 13 & R-M-L & other & Self-report & no \\
\hline $\begin{array}{l}\text { Narr et al. } \\
(2007)\end{array}$ & 67 & $\begin{array}{c}\text { general } \\
\text { population }\end{array}$ & European & R-nonR & EHI & 20 & R-M-L & handedness & Self-report & no \\
\hline $\begin{array}{l}\text { Newcombe \& } \\
\text { Ratcliff (1973) }\end{array}$ & 823 & $\begin{array}{c}\text { general } \\
\text { population }\end{array}$ & European & R-M-L & $\mathrm{n} / \mathrm{a}$ & 7 & $\mathrm{n} / \mathrm{a}$ & other & Self-report & no \\
\hline $\begin{array}{l}\text { Newcombe et } \\
\text { al. (1975) }\end{array}$ & 928 & $\begin{array}{c}\text { general } \\
\text { population }\end{array}$ & European & R-M-L & $\mathrm{n} / \mathrm{a}$ & 7 & R-L & other & Self-report & no \\
\hline $\begin{array}{l}\text { Nicholls, } \\
\text { Orr,Yates, \& } \\
\text { Loftus (2008) }\end{array}$ & 600 & $\begin{array}{l}\text { College } \\
\text { students }\end{array}$ & European & R-nonR & $\mathrm{n} / \mathrm{a}$ & $\mathrm{n} / \mathrm{a}$ & $\mathrm{n} / \mathrm{a}$ & handedness & Self-report & no \\
\hline $\begin{array}{l}\text { Nicholls, } \\
\text { Chapman, } \\
\text { Loetscher, \& } \\
\text { Grimshaw } \\
(2010)\end{array}$ & 825 & $\begin{array}{c}\text { general } \\
\text { population }\end{array}$ & $\mathrm{n} / \mathrm{a}$ & R-L & Annett's & 12 & $\mathrm{n} / \mathrm{a}$ & handedness & Self-report & no \\
\hline $\begin{array}{l}\text { Nicholls, } \\
\text { Thomas, } \\
\text { Loetscher, \& } \\
\text { Grimshaw } \\
\text { (2013) }\end{array}$ & 3,324 & $\begin{array}{l}\text { College } \\
\text { students }\end{array}$ & $\mathrm{n} / \mathrm{a}$ & R-M-L & $\mathrm{n} / \mathrm{a}$ & 31 & R-M-L & handedness & Self-report & no \\
\hline \multirow[t]{2}{*}{$\begin{array}{l}\text { Obrzut, Dalby, } \\
\text { Boliek, \& } \\
\text { Cannon (1992) }\end{array}$} & 318 & $\begin{array}{l}\text { College } \\
\text { students }\end{array}$ & European & R-L & $\mathrm{n} / \mathrm{a}$ & 14 & $\mathrm{n} / \mathrm{a}$ & handedness & Self-report & no \\
\hline & 206 & & European & & & 10 & & & & no \\
\hline
\end{tabular}


HUMAN HANDEDNESS: A META-ANALYSIS

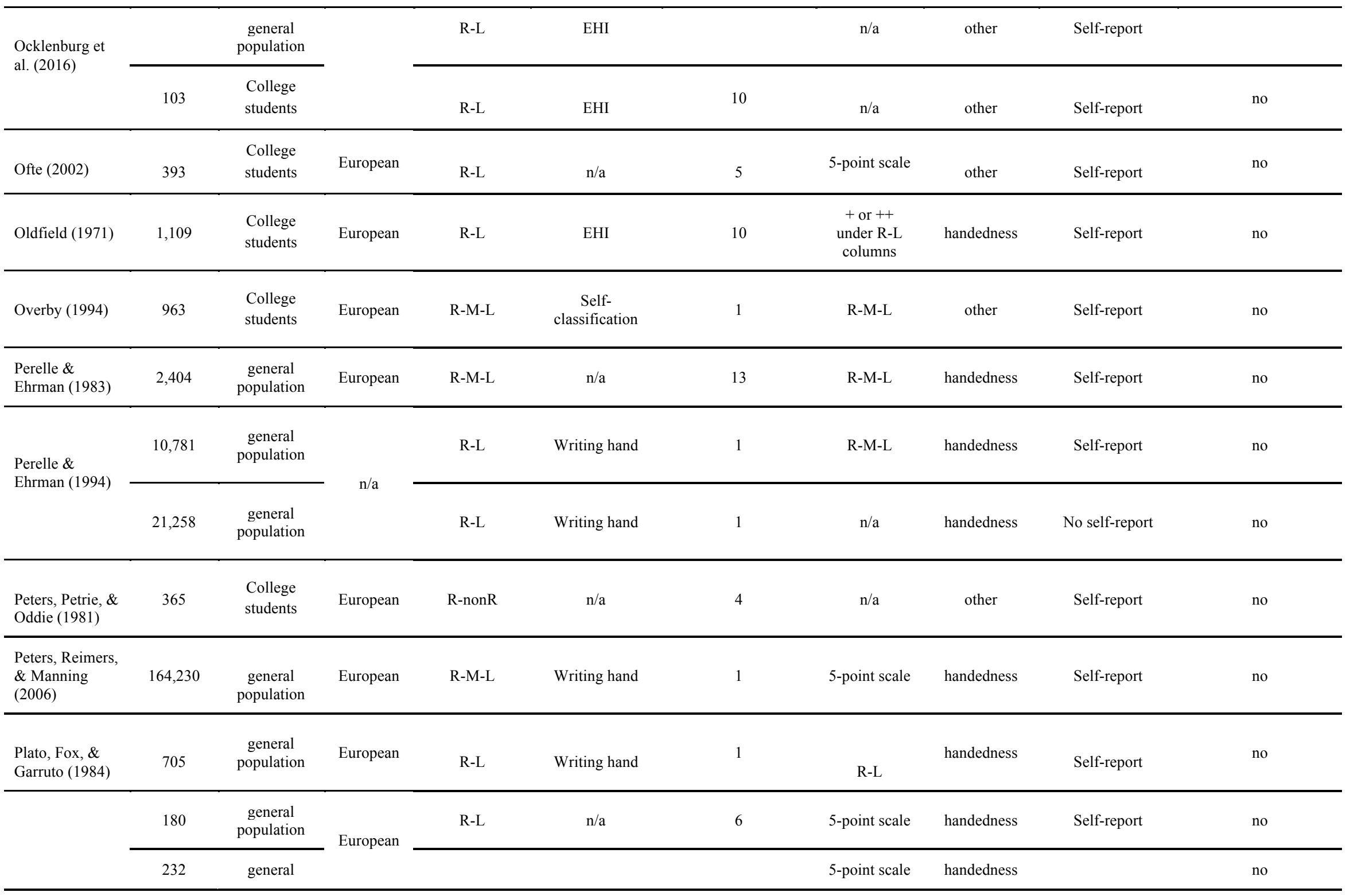


HUMAN HANDEDNESS: A META-ANALYSIS

\begin{tabular}{|c|c|c|c|c|c|c|c|c|c|c|}
\hline \multirow{3}{*}{ Porac (1993) } & \multicolumn{2}{|r|}{ population } & & R-L & $\mathrm{n} / \mathrm{a}$ & 6 & \multicolumn{4}{|c|}{ Self-report } \\
\hline & 127 & $\begin{array}{c}\text { general } \\
\text { population }\end{array}$ & & R-L & $\mathrm{n} / \mathrm{a}$ & 6 & 5 -point scale & handedness & Self-report & no \\
\hline & 93 & $\begin{array}{c}\text { general } \\
\text { population }\end{array}$ & & R-L & $\mathrm{n} / \mathrm{a}$ & 6 & 5 -point scale & handedness & Self-report & no \\
\hline $\begin{array}{l}\text { Porac, Coren, } \\
\text { \& Searleman } \\
\text { (1983) }\end{array}$ & 900 & $\begin{array}{c}\text { general } \\
\text { population }\end{array}$ & European & R-L & Writing hand & 1 & R-L & other & Self-report & no \\
\hline $\begin{array}{l}\text { Porfert \& } \\
\text { Rosenfield } \\
\text { (1978) }\end{array}$ & 2,107 & $\begin{array}{l}\text { College } \\
\text { students }\end{array}$ & European & R-nonR & $\mathrm{n} / \mathrm{a}$ & $\mathrm{n} / \mathrm{a}$ & $\mathrm{n} / \mathrm{a}$ & other & Self-report & no \\
\hline $\begin{array}{l}\text { Preti, Sisti, } \\
\text { Rocchi, Busca, } \\
\text { Vellante, \& } \\
\text { Camboni (2011) }\end{array}$ & 4,232 & $\begin{array}{c}\text { general } \\
\text { population }\end{array}$ & European & R-M-L & Writing hand & 1 & $\mathrm{n} / \mathrm{a}$ & handedness & Self-report & no \\
\hline $\begin{array}{l}\text { Preti et al. } \\
\text { (2012) }\end{array}$ & 1,004 & $\begin{array}{c}\text { general } \\
\text { population }\end{array}$ & European & R-L & Writing hand & 1 & $\mathrm{n} / \mathrm{a}$ & handedness & Self-report & no \\
\hline $\begin{array}{l}\text { Ravichandran, } \\
\text { Shinn, Öngür, } \\
\text { Perlis, \& Cohen } \\
\text { (2017) }\end{array}$ & 253 & $\begin{array}{c}\text { general } \\
\text { population }\end{array}$ & European & R-nonR & $\begin{array}{c}\text { Self- } \\
\text { classification }\end{array}$ & 1 & $\mathrm{R}-\mathrm{L}$ & handedness & Self-report & no \\
\hline \multirow{3}{*}{$\begin{array}{l}\text { Raymond, } \\
\text { Pontier, Dufour, } \\
\text { \& Moller } \\
(1996)\end{array}$} & 350 & $\begin{array}{l}\text { College } \\
\text { students }\end{array}$ & European & R-L & Writing hand & 1 & R-L & handedness & Self-report & no \\
\hline & 542 & $\begin{array}{c}\text { general } \\
\text { population }\end{array}$ & $\mathrm{n} / \mathrm{a}$ & R-L & $\begin{array}{l}\text { Observation of } \\
\text { an action/official } \\
\text { records }\end{array}$ & 1 & $\mathrm{n} / \mathrm{a}$ & handedness & No self-report & yes \\
\hline & 75 & $\begin{array}{c}\text { general } \\
\text { population }\end{array}$ & European & R-L & $\begin{array}{l}\text { Observation of } \\
\text { an action/official } \\
\text { records }\end{array}$ & 1 & $\mathrm{n} / \mathrm{a}$ & handedness & No self-report & yes \\
\hline
\end{tabular}


HUMAN HANDEDNESS: A META-ANALYSIS

\begin{tabular}{|c|c|c|c|c|c|c|c|c|c|c|}
\hline $\begin{array}{l}\text { Reina, } \\
\text { Cavaignac, } \\
\text { Trousdale, } \\
\text { Laffosse, \& } \\
\text { Braga (2017) }\end{array}$ & 17 & $\begin{array}{c}\text { general } \\
\text { population }\end{array}$ & $\mathrm{n} / \mathrm{a}$ & R-L & $\begin{array}{c}\text { Self- } \\
\text { classification }\end{array}$ & 1 & $\mathrm{n} / \mathrm{a}$ & handedness & Self-report & no \\
\hline $\begin{array}{l}\text { Reiss \& Reiss } \\
\text { (1997) }\end{array}$ & 936 & $\begin{array}{l}\text { College } \\
\text { students }\end{array}$ & European & R-nonR & $\begin{array}{c}4 \text { items from } \\
\text { Porac \& Coren } \\
\text { Laterality } \\
\text { Inventory }\end{array}$ & 4 & R-M-L & handedness & Self-report & no \\
\hline $\begin{array}{l}\text { Reiss et al. } \\
\text { (1998) }\end{array}$ & 1,223 & $\begin{array}{l}\text { College } \\
\text { students }\end{array}$ & European & R-M-L & $\begin{array}{c}\text { Self- } \\
\text { classification }\end{array}$ & 1 & R-M-L & handedness & Self-report & no \\
\hline \multirow[t]{2}{*}{ Rife (1940) } & 2,178 & $\begin{array}{l}\text { College } \\
\text { students }\end{array}$ & \multirow{2}{*}{ European } & R-nonR & $\mathrm{n} / \mathrm{a}$ & 10 & R-M-L & handedness & Self-report & no \\
\hline & 1,374 & $\begin{array}{c}\text { general } \\
\text { population }\end{array}$ & & R-nonR & $\mathrm{n} / \mathrm{a}$ & $\mathrm{n} / \mathrm{a}$ & R-M-L & handedness & Self-report & no \\
\hline \multirow{2}{*}{$\begin{array}{l}\text { Risch \& Pringle } \\
\text { (1985) }\end{array}$} & 4,263 & $\mathrm{n} / \mathrm{a}$ & European & $\mathrm{R}-\mathrm{L}$ & $\mathrm{n} / \mathrm{a}$ & 11 & $\mathrm{n} / \mathrm{a}$ & handedness & $\mathrm{n} / \mathrm{a}$ & no \\
\hline & 3,128 & $\begin{array}{c}\text { general } \\
\text { population }\end{array}$ & European & $\mathrm{R}-\mathrm{L}$ & $\mathrm{n} / \mathrm{a}$ & 1 & R-M-L & handedness & No self-report & no \\
\hline $\begin{array}{l}\text { Robinson, } \\
\text { Hurd, Read, \& } \\
\text { Crespi (2016) }\end{array}$ & 708 & $\begin{array}{l}\text { College } \\
\text { students }\end{array}$ & European & R-M-L & $\mathrm{n} / \mathrm{a}$ & 32 & 5 -point scale & handedness & Self-report & no \\
\hline $\begin{array}{l}\text { Rosenstein \& } \\
\text { Bigler (1987) }\end{array}$ & 50 & $\begin{array}{l}\text { College } \\
\text { students }\end{array}$ & European & R-L & EHI & 10 & R-L & other & Self-report & no \\
\hline \multirow{2}{*}{$\begin{array}{l}\text { Sakano \& } \\
\text { Pickenhain } \\
\text { (1985) }\end{array}$} & 998 & $\begin{array}{l}\text { College } \\
\text { students }\end{array}$ & East Asian & R-M-L & $\mathrm{n} / \mathrm{a}$ & 5 & R-M-L & handedness & Self-report & no \\
\hline & 690 & $\begin{array}{l}\text { College } \\
\text { students }\end{array}$ & European & R-M-L & $\mathrm{n} / \mathrm{a}$ & 5 & R-M-L & handedness & Self-report & no \\
\hline
\end{tabular}


HUMAN HANDEDNESS: A META-ANALYSIS

\begin{tabular}{|c|c|c|c|c|c|c|c|c|c|c|}
\hline $\begin{array}{l}\text { Salmaso \& } \\
\text { Longoni (1985) }\end{array}$ & 1,694 & $\mathrm{n} / \mathrm{a}$ & European & R-L & $\mathrm{n} / \mathrm{a}$ & 20 & $\begin{array}{l}+ \text { or }++ \\
\text { under R-L } \\
\text { columns }\end{array}$ & handedness & Self-report & no \\
\hline \multirow{6}{*}{$\begin{array}{l}\text { Sanders, } \\
\text { Wilson, \& } \\
\text { Vandenberg } \\
(1982)\end{array}$} & 341 & $\begin{array}{c}\text { general } \\
\text { population }\end{array}$ & European & R-M-L & $\mathrm{n} / \mathrm{a}$ & $\mathrm{n} / \mathrm{a}$ & R-M-L & other & Self-report & no \\
\hline & 224 & $\begin{array}{l}\text { general } \\
\text { population }\end{array}$ & European & R-M-L & $\mathrm{n} / \mathrm{a}$ & $\mathrm{n} / \mathrm{a}$ & R-M-L & other & Self-report & no \\
\hline & 143 & $\begin{array}{c}\text { general } \\
\text { population }\end{array}$ & East Asian & R-M-L & $\mathrm{n} / \mathrm{a}$ & $\mathrm{n} / \mathrm{a}$ & R-M-L & other & Self-report & no \\
\hline & 78 & $\begin{array}{c}\text { general } \\
\text { population }\end{array}$ & East Asian & R-M-L & $\mathrm{n} / \mathrm{a}$ & $\mathrm{n} / \mathrm{a}$ & R-M-L & other & Self-report & no \\
\hline & 55 & $\begin{array}{c}\text { general } \\
\text { population }\end{array}$ & East Asian & R-M-L & $\mathrm{n} / \mathrm{a}$ & $\mathrm{n} / \mathrm{a}$ & R-M-L & other & Self-report & no \\
\hline & 38 & $\begin{array}{l}\text { general } \\
\text { population }\end{array}$ & East Asian & R-M-L & $\mathrm{n} / \mathrm{a}$ & $\mathrm{n} / \mathrm{a}$ & R-M-L & other & Self-report & no \\
\hline $\begin{array}{l}\text { Saunders \& } \\
\text { Campbell } \\
\text { (1985) }\end{array}$ & 372 & $\mathrm{n} / \mathrm{a}$ & $\mathrm{n} / \mathrm{a}$ & R-M-L & EHI & 10 & R-M-L & handedness & Self-report & no \\
\hline Savel (2009) & 50 & $\begin{array}{c}\text { general } \\
\text { population }\end{array}$ & European & R-L & EHI & 10 & R-M-L & handedness & Self-report & no \\
\hline $\begin{array}{l}\text { Schachter, } \\
\text { Ransil, \& } \\
\text { Geschwind } \\
(1987)\end{array}$ & 1,117 & $\begin{array}{l}\text { College } \\
\text { students }\end{array}$ & European & R-nonR & EHI & 10 & 5 -point scale & handedness & Self-report & no \\
\hline $\begin{array}{l}\text { Searleman \& } \\
\text { Fugagli (1987) }\end{array}$ & 277 & $\begin{array}{l}\text { College } \\
\text { students }\end{array}$ & European & $\mathrm{R}-\mathrm{L}$ & Writing hand & 1 & R-L & other & Self-report & no \\
\hline $\begin{array}{l}\text { Searleman, } \\
\text { Porac, \& Coren } \\
\text { (1984) }\end{array}$ & 3,709 & $\begin{array}{l}\text { College } \\
\text { students }\end{array}$ & European & R-L & $\begin{array}{l}4 \text { items from } \\
\text { Porac \& Coren } \\
\text { Laterality } \\
\text { Inventory }\end{array}$ & 4 & R-M-L & other & Self-report & no \\
\hline
\end{tabular}


HUMAN HANDEDNESS: A META-ANALYSIS

\begin{tabular}{|c|c|c|c|c|c|c|c|c|c|c|}
\hline $\begin{array}{l}\text { Searleman, } \\
\text { Tweedy, \& } \\
\text { Springer (1979) }\end{array}$ & 847 & $\begin{array}{l}\text { College } \\
\text { students }\end{array}$ & European & R-M-L & $\mathrm{n} / \mathrm{a}$ & 14 & 5-point scale & other & Self-report & no \\
\hline Segal (1984) & 1,577 & $\mathrm{n} / \mathrm{a}$ & European & $\mathrm{R}-\mathrm{L}$ & Writing hand & 1 & R-M-L & handedness & Self-report & no \\
\hline \multirow{2}{*}{$\begin{array}{l}\text { Shan-Ming et } \\
\text { al.g (1985) }\end{array}$} & 201 & $\begin{array}{c}\text { general } \\
\text { population }\end{array}$ & East Asian & R-nonR & $\mathrm{n} / \mathrm{a}$ & 10 & $\mathrm{R}-\mathrm{L}$ & handedness & Self-report & no \\
\hline & 231 & $\begin{array}{c}\text { general } \\
\text { population }\end{array}$ & East Asian & R-nonR & $\mathrm{n} / \mathrm{a}$ & 10 & R-L & handedness & Self-report & no \\
\hline Sherman (1979) & 98 & $\begin{array}{c}\text { general } \\
\text { population }\end{array}$ & European & R-nonR & $\mathrm{n} / \mathrm{a}$ & 14 & 5-point scale & other & Self-report & no \\
\hline $\begin{array}{l}\text { Shettel-Neuber } \\
\text { \& O'Reilly } \\
\text { (1983) }\end{array}$ & 218 & $\begin{array}{l}\text { College } \\
\text { students }\end{array}$ & European & R-M-L & $\mathrm{n} / \mathrm{a}$ & 1 & R-M-L & other & Self-report & no \\
\hline $\begin{array}{l}\text { Shimizu \& } \\
\text { Endo (1983) }\end{array}$ & 4,282 & $\begin{array}{c}\text { general } \\
\text { population }\end{array}$ & East Asian & R-M-L & $\mathrm{n} / \mathrm{a}$ & 13 & 5-point scale & handedness & Self-report & no \\
\hline $\begin{array}{l}\text { Singh \& Bryden } \\
\text { (1994) }\end{array}$ & 729 & $\mathrm{n} / \mathrm{a}$ & $\mathrm{n} / \mathrm{a}$ & R-L & $\mathrm{n} / \mathrm{a}$ & 10 & 5-point scale & handedness & Self-report & no \\
\hline Smith (1987) & 350 & $\begin{array}{c}\text { general } \\
\text { population }\end{array}$ & European & $\mathrm{R}-\mathrm{L}$ & EHI & 10 & $\mathrm{n} / \mathrm{a}$ & other & Self-report & no \\
\hline \multirow{2}{*}{$\begin{array}{l}\text { Spiegler \& } \\
\text { Yeni-Komshian } \\
(1983)\end{array}$} & 1,816 & $\begin{array}{l}\text { College } \\
\text { students }\end{array}$ & European & $\mathrm{R}-\mathrm{L}$ & Writing hand & 1 & $\mathrm{n} / \mathrm{a}$ & handedness & Self-report & no \\
\hline & 3,632 & $\begin{array}{c}\text { general } \\
\text { population }\end{array}$ & European & $\mathrm{R}-\mathrm{L}$ & Writing hand & 1 & R-M-L & handedness & No self-report & no \\
\hline $\begin{array}{l}\text { Stoyanov, } \\
\text { Nikolova, \& } \\
\text { Pashalieva } \\
(2011)\end{array}$ & 3,182 & $\begin{array}{l}\text { College } \\
\text { students }\end{array}$ & European & R-nonR & Annett's & 12 & $\mathrm{n} / \mathrm{a}$ & handedness & Self-report & no \\
\hline $\begin{array}{l}\text { Suar, Mandal, } \\
\text { Misra \& Suman } \\
\text { (2013) }\end{array}$ & 3,698 & $\begin{array}{c}\text { general } \\
\text { population }\end{array}$ & $\mathrm{n} / \mathrm{a}$ & R-L & Writing hand & 1 & 5-point scale & handedness & Self-report & no \\
\hline
\end{tabular}


HUMAN HANDEDNESS: A META-ANALYSIS

\begin{tabular}{|c|c|c|c|c|c|c|c|c|c|c|}
\hline Tan (1986) & 266 & $\begin{array}{l}\text { College } \\
\text { students }\end{array}$ & $\mathrm{n} / \mathrm{a}$ & R-M-L & Annett's & 12 & $\mathrm{n} / \mathrm{a}$ & other & Self-report & no \\
\hline Tan (1988) & 1,100 & $\begin{array}{l}\text { College } \\
\text { students }\end{array}$ & $\mathrm{n} / \mathrm{a}$ & R-M-L & EHI & 10 & 5-point scale & handedness & Self-report & no \\
\hline $\begin{array}{l}\text { Tapley \& } \\
\text { Bryden (1985) }\end{array}$ & 1,511 & $\begin{array}{l}\text { College } \\
\text { students }\end{array}$ & European & $\mathrm{R}-\mathrm{L}$ & $\mathrm{n} / \mathrm{a}$ & 8 & 5-point scale & handedness & Self-report & no \\
\hline $\begin{array}{l}\text { Teng, Lee, } \\
\text { Yang, \& Chang } \\
\text { (1979) }\end{array}$ & 2,041 & $\begin{array}{l}\text { College } \\
\text { students }\end{array}$ & East Asian & R-L & $\mathrm{n} / \mathrm{a}$ & 12 & $\begin{array}{c}+ \text { or }++ \\
\text { under R-L } \\
\text { columns }\end{array}$ & handedness & Self-report & no \\
\hline $\begin{array}{l}\text { Thompson \& } \\
\text { Marsh (1976) }\end{array}$ & 1,299 & $\begin{array}{c}\text { general } \\
\text { population }\end{array}$ & European & R-M-L & $\mathrm{n} / \mathrm{a}$ & 4 & $/ \mathrm{a}$ & handedness & Self-report & no \\
\hline $\begin{array}{l}\text { Tonetti, Adan, } \\
\text { Caci, Fabbri, \& } \\
\text { Natale (2012) }\end{array}$ & 3,473 & $\begin{array}{l}\text { College } \\
\text { students }\end{array}$ & European & $\mathrm{R}-\mathrm{L}$ & EHI & 10 & $\mathrm{n} / \mathrm{a}$ & handedness & Self-report & no \\
\hline $\begin{array}{l}\text { Tran, Stieger, \& } \\
\text { Voracek (2014) }\end{array}$ & 12,720 & $\begin{array}{c}\text { general } \\
\text { population }\end{array}$ & European & R-M-L & $\mathrm{n} / \mathrm{a}$ & 12 & R-M-L & handedness & Self-report & no \\
\hline $\begin{array}{l}\text { Tsuang, Chen } \\
\text { Kuo, \& Hsiao } \\
(2016)\end{array}$ & 3,445 & $\begin{array}{l}\text { College } \\
\text { students }\end{array}$ & East Asian & $\mathrm{R}-\mathrm{L}$ & Writing hand & 1 & 5-point scale & handedness & Self-report & no \\
\hline $\begin{array}{l}\text { Walker \& } \\
\text { Henneberg } \\
(2007)\end{array}$ & 21 & $\begin{array}{c}\text { general } \\
\text { population }\end{array}$ & European & R-M-L & EHI & 12 & $\mathrm{n} / \mathrm{a}$ & handedness & Self-report & no \\
\hline $\begin{array}{l}\text { Wolf, } \\
\text { D'Agostino, \& } \\
\text { Cobb (1991) }\end{array}$ & 2,088 & $\begin{array}{c}\text { general } \\
\text { population }\end{array}$ & European & $\mathrm{R}-\mathrm{L}$ & $\mathrm{n} / \mathrm{a}$ & $\mathrm{n} / \mathrm{a}$ & R-M-L & handedness & Self-report & no \\
\hline $\begin{array}{l}\text { Wood \& } \\
\text { Aggleton } \\
\text { (1989) }\end{array}$ & 752 & $\mathrm{n} / \mathrm{a}$ & European & R-M-L & $\begin{array}{l}\text { Observation of } \\
\text { an action/official } \\
\text { records }\end{array}$ & 1 & R-M-L & other & No self-report & yes \\
\hline $\begin{array}{l}\text { Wood \& } \\
\text { Aggleton } \\
\text { (1991) }\end{array}$ & 1,240 & $\begin{array}{l}\text { College } \\
\text { students }\end{array}$ & European & R-L & EHI & 10 & R-M-L & other & Self-report & no \\
\hline
\end{tabular}


HUMAN HANDEDNESS: A META-ANALYSIS

\begin{tabular}{|c|c|c|c|c|c|c|c|c|c|c|}
\hline $\begin{array}{l}\text { Xu \& Zheng } \\
\text { (2017) }\end{array}$ & 946 & $\begin{array}{c}\text { general } \\
\text { population }\end{array}$ & East Asian & R-M-L & Writing hand & 1 & R-M-L & handedness & Self-report & no \\
\hline $\begin{array}{l}\text { You et al. } \\
\text { (2013) }\end{array}$ & 40 & $\begin{array}{l}\text { College } \\
\text { students }\end{array}$ & East Asian & R-M-L & $\begin{array}{c}\text { Self- } \\
\text { classification }\end{array}$ & 1 & $\mathrm{n} / \mathrm{a}$ & other & Self-report & no \\
\hline $\begin{array}{c}\text { Yule, Brotto, \& } \\
\text { Gorzalka (2015) }\end{array}$ & 690 & $\begin{array}{c}\text { general } \\
\text { population }\end{array}$ & $\mathrm{n} / \mathrm{a}$ & R-nonR & EHI & 10 & $\mathrm{n} / \mathrm{a}$ & handedness & Self-report & no \\
\hline $\begin{array}{l}\text { Zhu et al. } \\
\text { (2009) }\end{array}$ & 18,468 & $\begin{array}{c}\text { general } \\
\text { population }\end{array}$ & European & R-M-L & $\begin{array}{c}\text { Self- } \\
\text { classification }\end{array}$ & 1 & 5-point scale & handedness & Self-report & no \\
\hline
\end{tabular}




\section{Figure captions}

Figure 1. Flow diagram for the search (October 2007 - June 2018) and inclusion criteria for studies in the systematic review and meta-analysis. The figure was created according to the guidelines of the PRISMA statement (Moher et al., 2009).

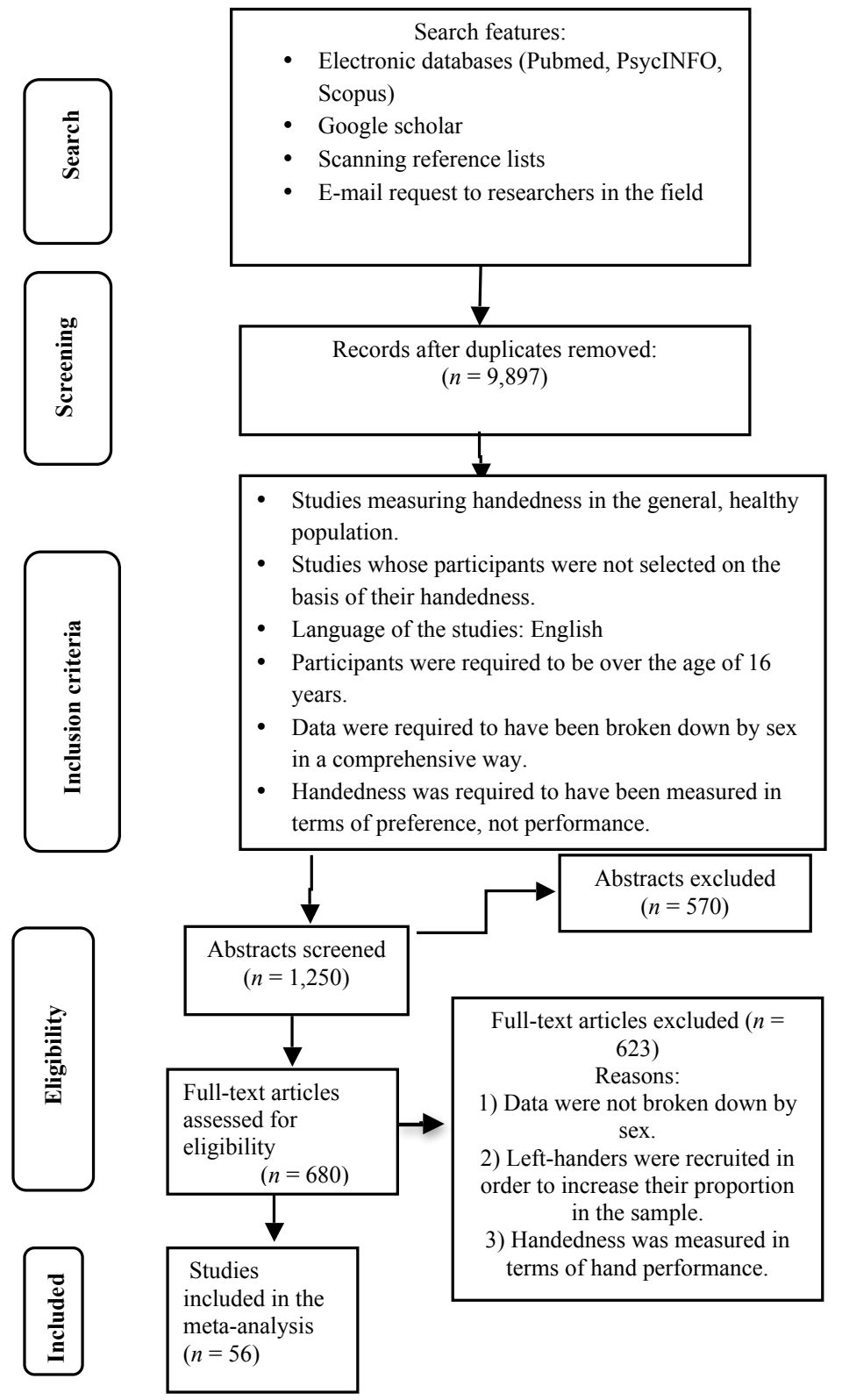

Figure 2. Sex differences in point estimates and funnel plots of standard error on log event rate for the left-handedness (total) $[\mathrm{A}, \mathrm{B}]$, non-right-handedness $[\mathrm{C}, \mathrm{D}]$, left-handedness 
(forced choice) [E, F], left-handedness (stringent) [G, H], and mixed-handedness [I, J] comparisons. Error bars represent the 95\% CI.

A

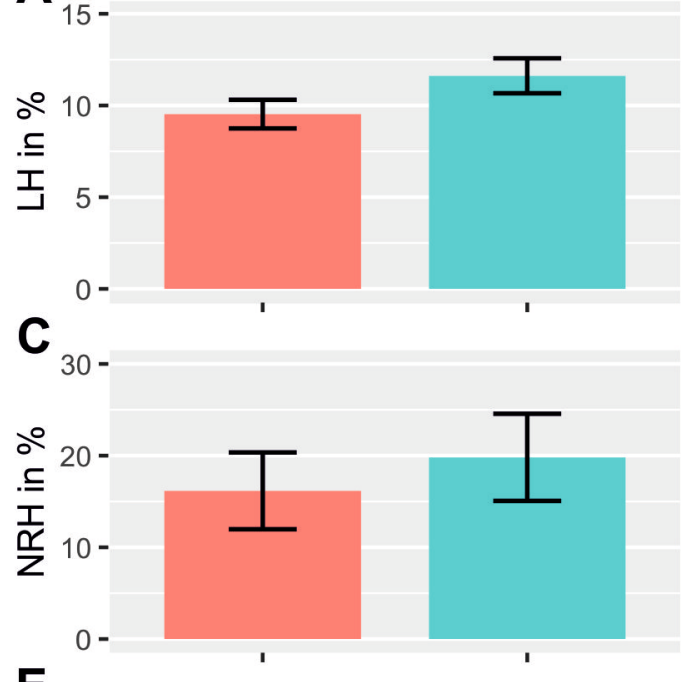

$\mathbf{E}$

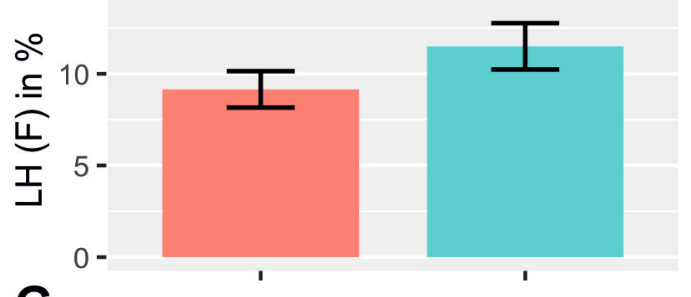

G

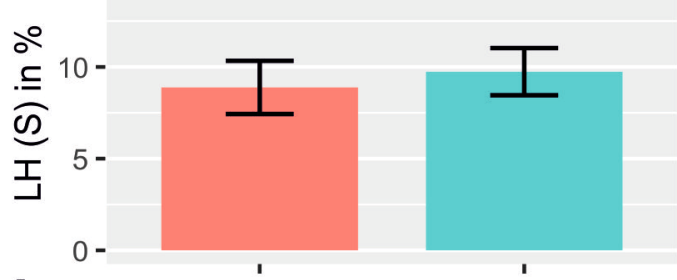

I

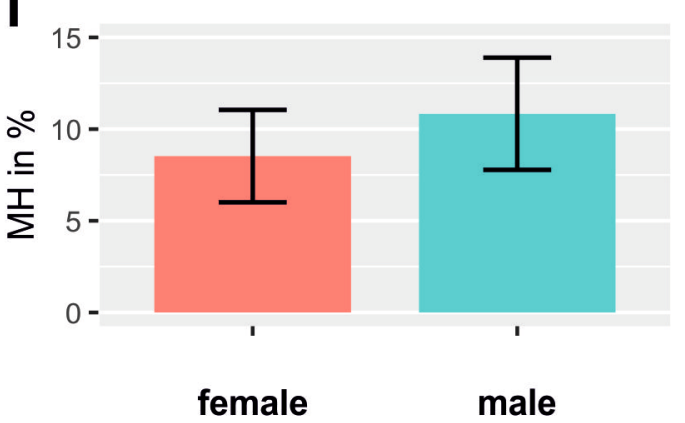

B
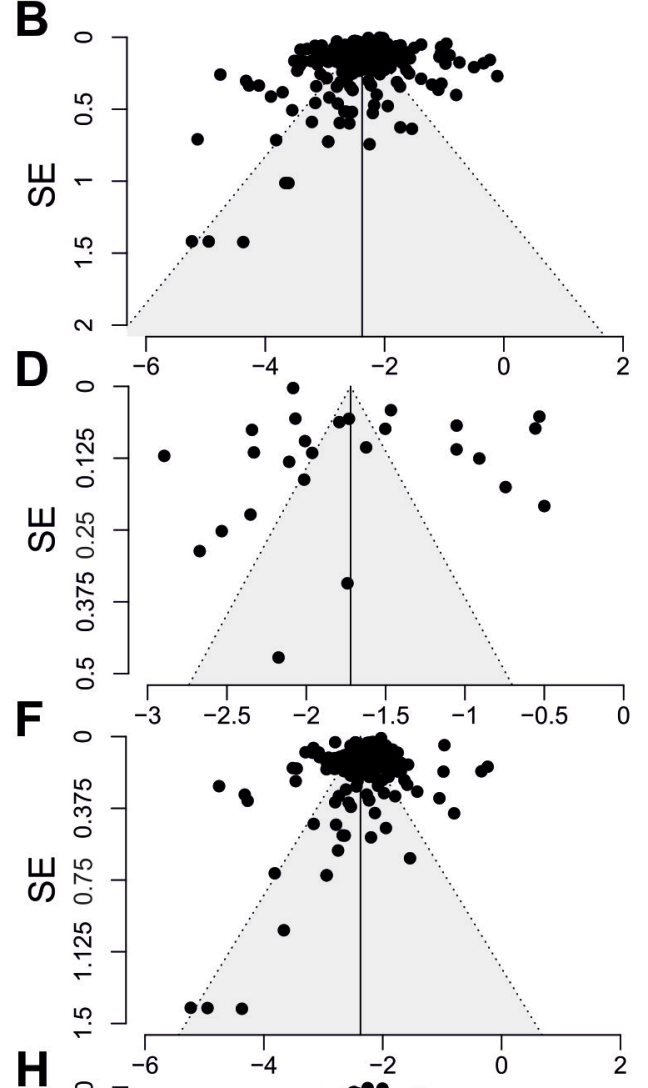

H
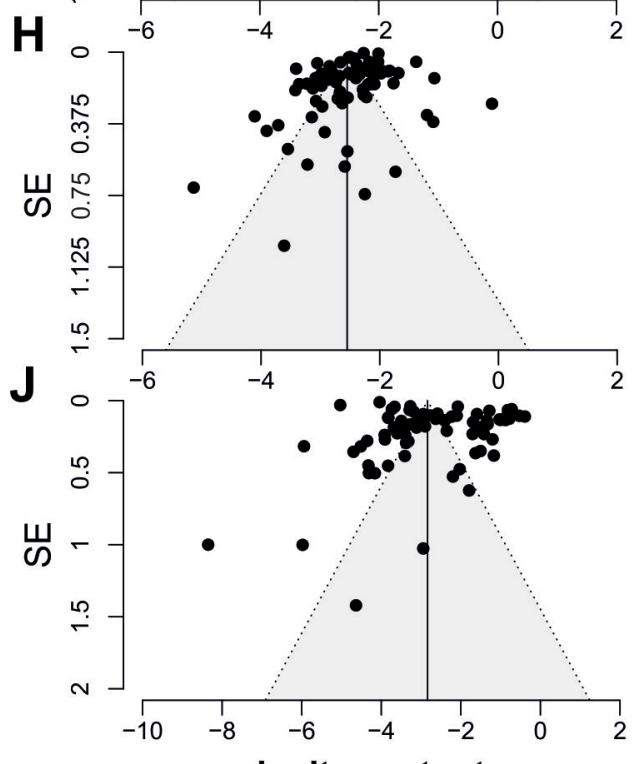

logit event rate 
Figure 3. Forest plot for the left-handedness (total) comparison grouped by year of publication (categorical). In the plot the $95 \%$ confidence interval for each study is represented by a horizontal line and the point estimate is represented by a dot. The dashed line indicates the overall estimate of left-handedness prevalence.

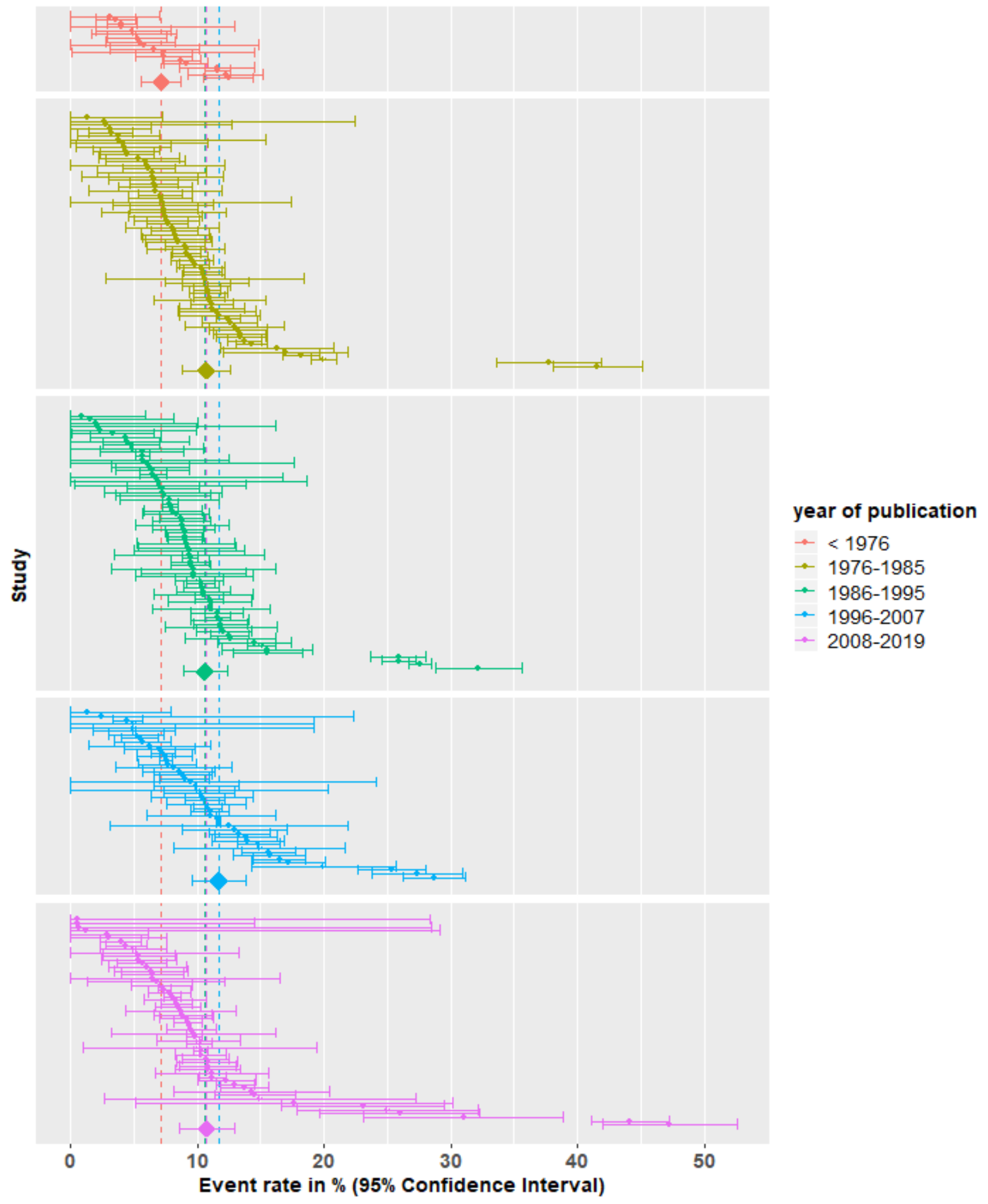


Figure 4. Forest plot for the left-handedness (total) comparison grouped by classification. In the plot the $95 \%$ confidence interval for each study is represented by a horizontal line and the point estimate is represented by a dot. The dashed line indicates the overall estimate of lefthandedness prevalence.

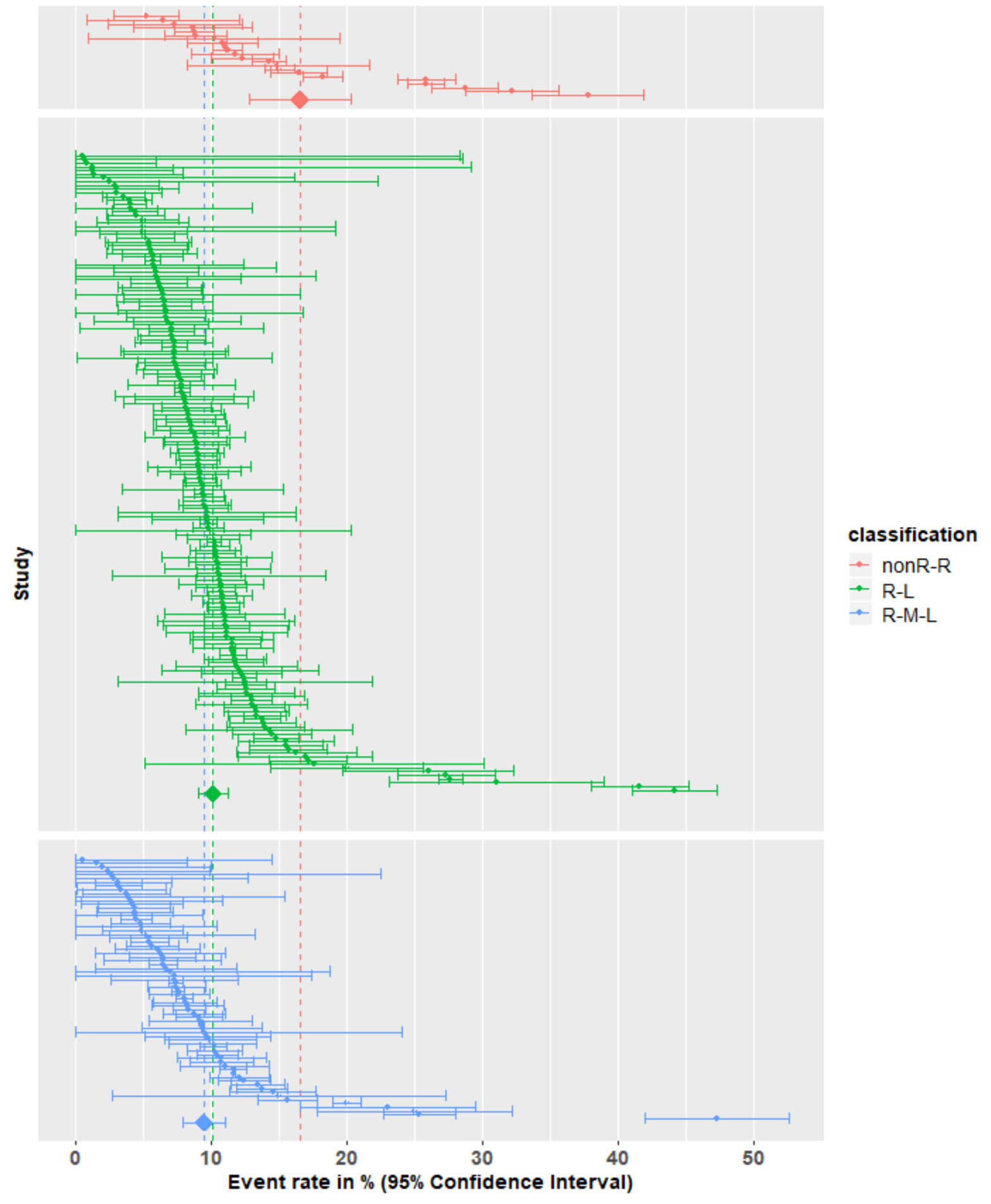


Figure 5. Forest plot for the left-handedness (total) comparison grouped by instruments used to assess handedness. In the plot the $95 \%$ confidence interval for each study is represented by a horizontal line and the point estimate is represented by a dot. The dashed line indicates the overall estimate of left-handedness prevalence.

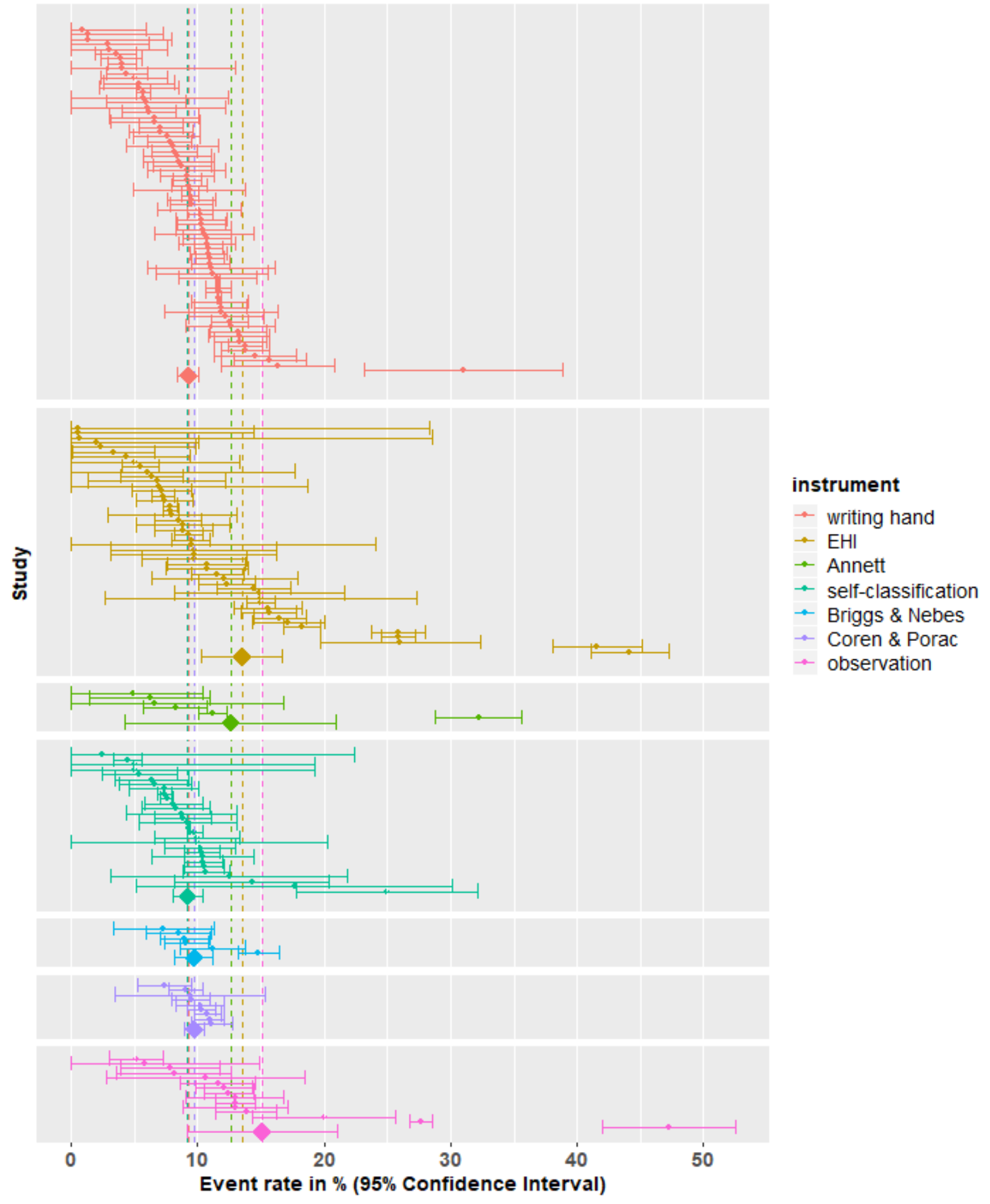


Figure 6. Scattergram visualizing the event rates of individual studies against their respective standard errors.

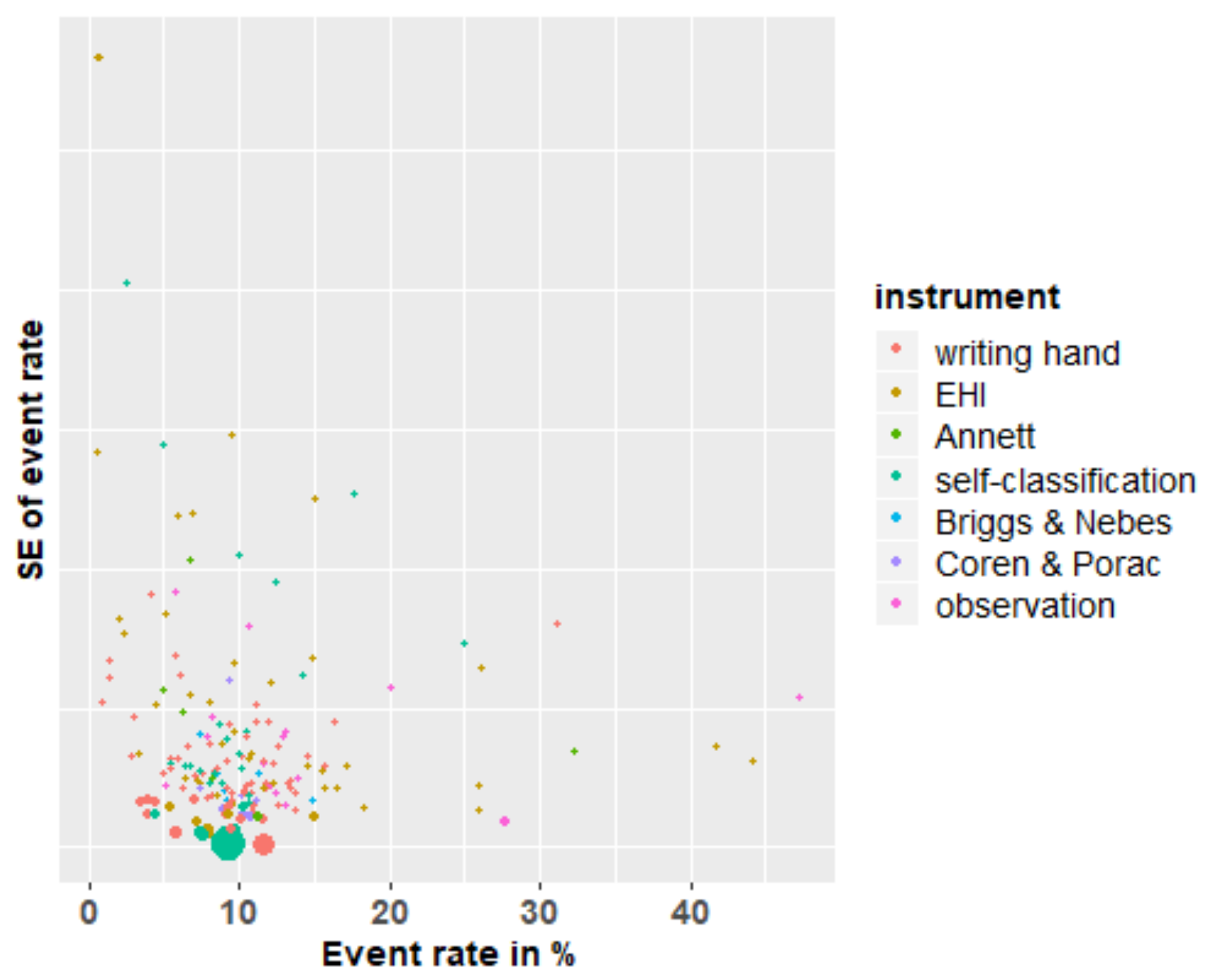


Figure 7. Forest plot for the left-handedness (total) comparison grouped by geographical ancestry. In the plot the $95 \%$ confidence interval for each study is represented by a horizontal line and the point estimate is represented by a dot. The dashed line indicates the overall estimate of left-handedness prevalence.

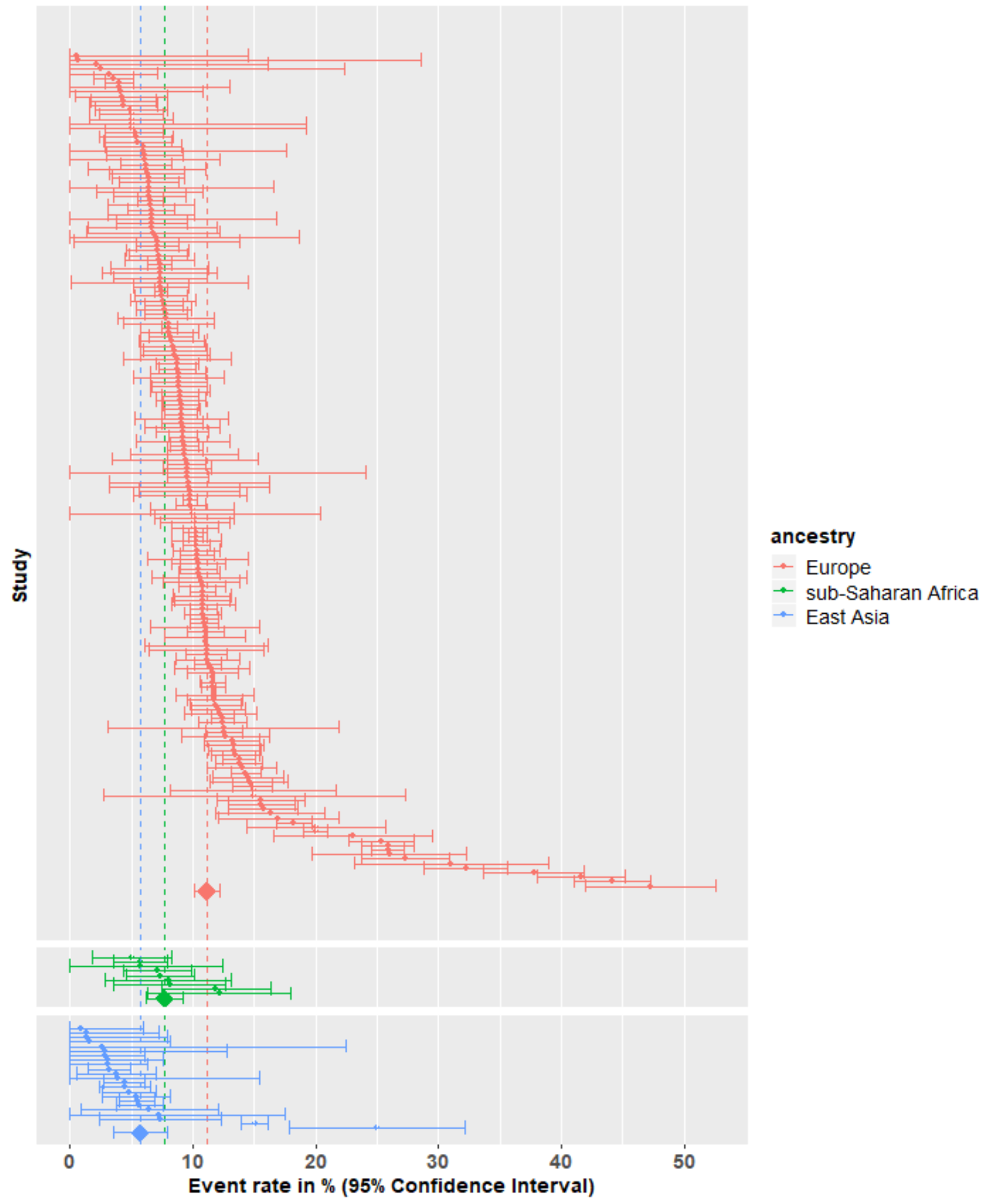




\section{Supplementary Figure Captions}

Supplementary Figure 1. Forest plot for the left-handedness (total) comparison. In the plot the $95 \%$ confidence interval for each study is represented by a horizontal line and the point estimate is represented by a dot. The dashed line indicates the overall estimate of lefthandedness prevalence $(10.60 \%)$.

Please find figure here: https://osf.io/9abp5/ 